Nevada

Environmental

Restoration

Project

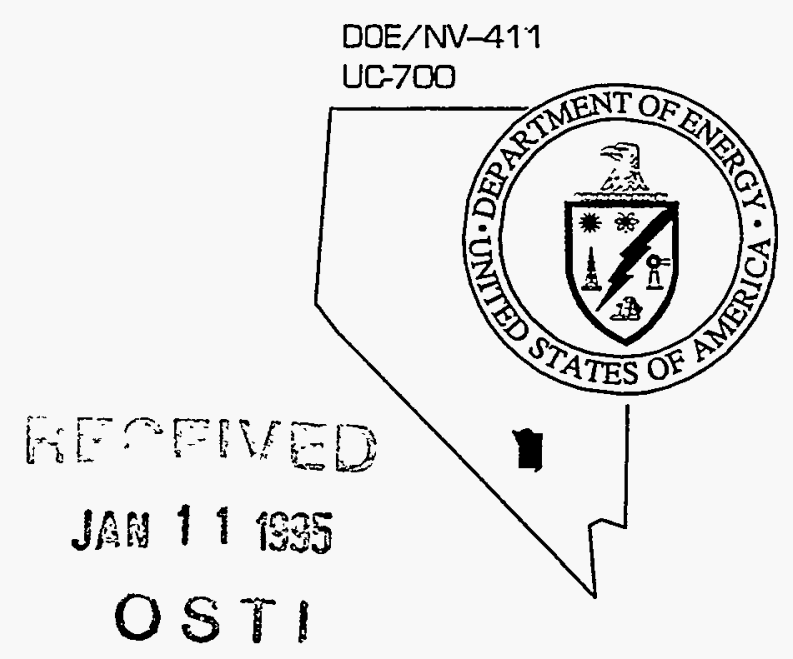

Work Plan Addendum for the

Remedial Investigation and

Feasibility Study

of the Salmon Site

November 1995

Environmental Restoration

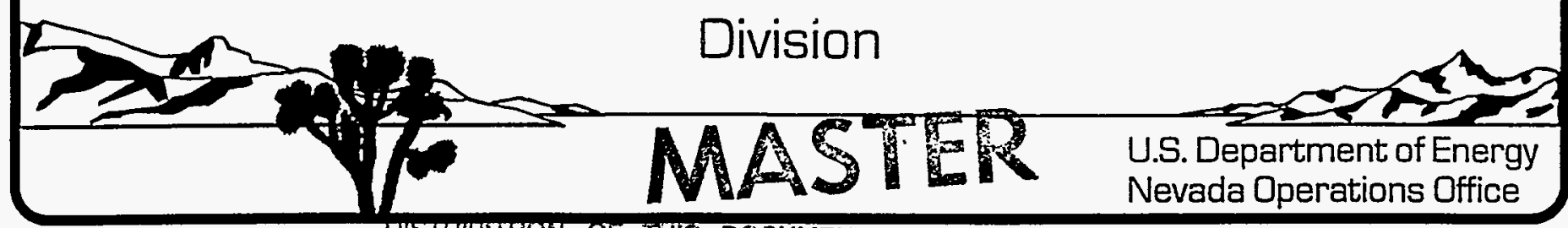


This report has been reproduced from the best available copy. Available in paper copy and microfiche.

Number of pages in this report: 118

DOE and DOE contractors can obtain copies of this report from: Office of Scientific and Technical Information, P.O. Box 62. Oak Ridge, TN 37831. (615) 576-8401.

This report is publicly available from the Department of Commerce, National Technical Information Service, 5285 Port Royal Road, Springfield, VA 22161. (703) 487-4650. 


\title{
WORK PLAN ADDENDUM FOR THE REMEDIAL INVESTIGATION AND FEASIBILITY STUDY OF THE SALMON SITE
}

\author{
Prepared for \\ DOE Nevada Operations Office \\ Las Vegas. Nevada
}

Prepared by

IT CORPORATION

4330 South Valley View Boulevard. Suite 114

Las Vegas. Nevada 89103

November 1996

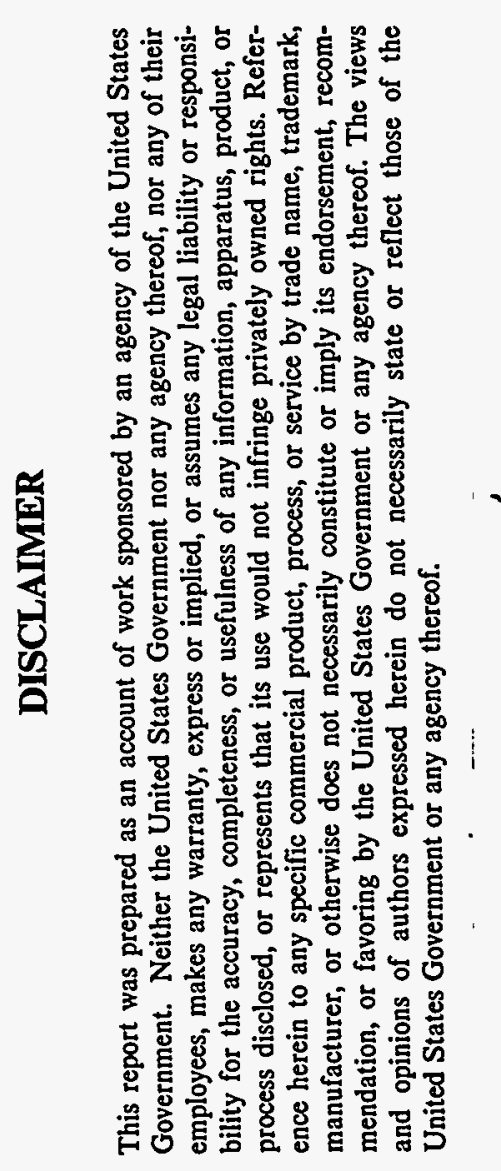

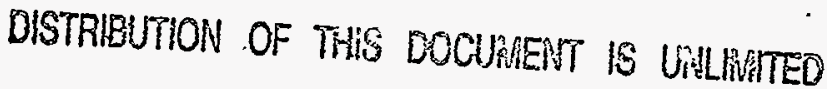





\section{WORK PLAN ADDENDUM FOR THE REMEDIAL INVESTIGATION AND FEASIBILITY STUDY OF THE SALMON SITE}

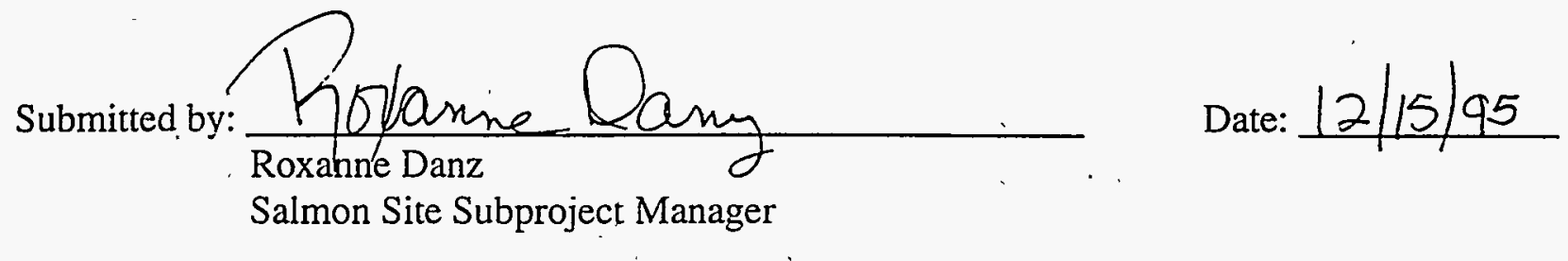

Approved by: $\frac{\text { Srephen Af Medlin, ton }}{\text { Stephen A. Mellington. Project Manager }} \quad$ Date: 12/15/95 Nevada Environmental Restoration Project 



\section{Table of Contents}

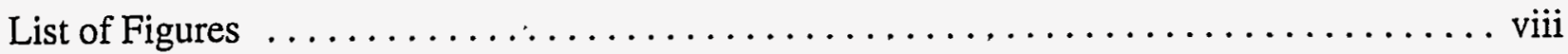

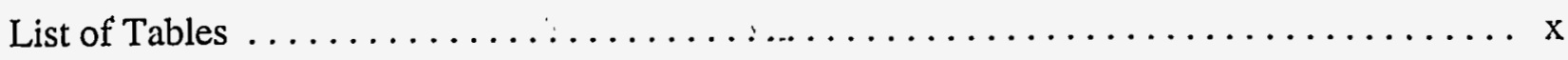

List of Acronyms and Abbreviations $\ldots \ldots \ldots \ldots \ldots \ldots \ldots \ldots \ldots \ldots \ldots \ldots \ldots \ldots \ldots \ldots \ldots \ldots$

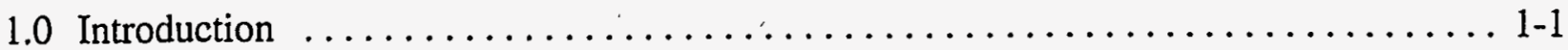

1.1 Purpose and Scope of the Remedial Investigation and Feasibility Study $\ldots \ldots \ldots 1-1$

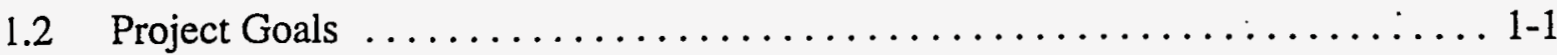

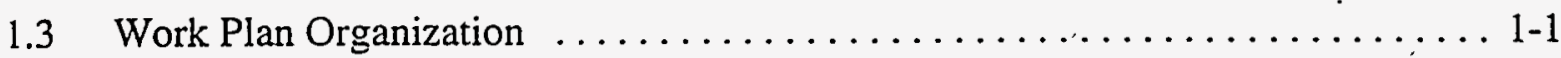

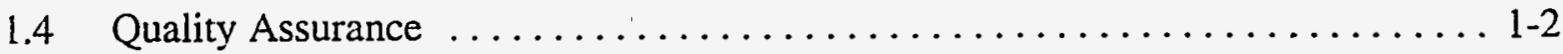

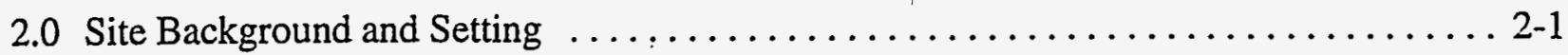

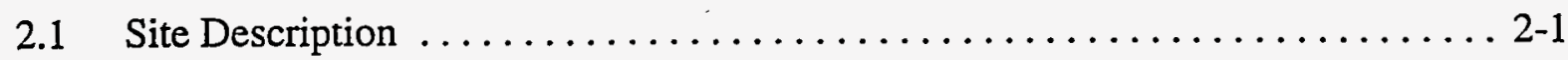

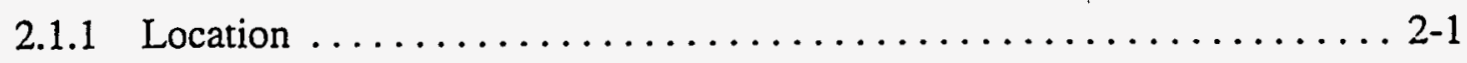

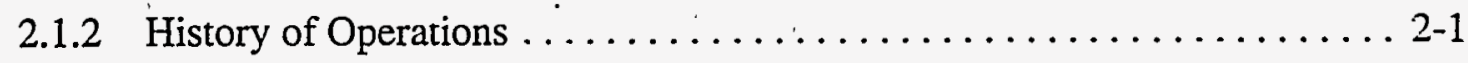

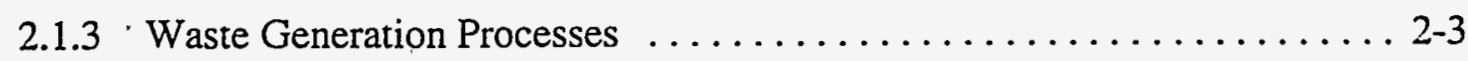

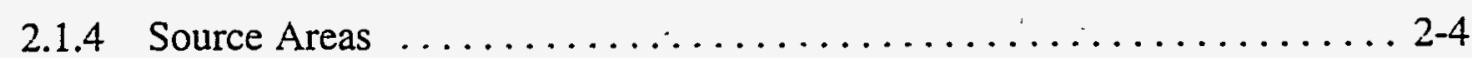

2.1.4.1 Source Area 1 - Surface Ground Zero $\ldots \ldots \ldots \ldots \ldots .2-4$

2.1.4.2 Source Area 2 - Northern Disposal Area ............ 2-4

2.1.4.3 Source Area 3 - Southern Storage Area ............ 2-11

2.1.4.4 Source Area 4 - Western Disposal Area ............. 2-11

2.1.4.5 Source Area 5 - Injection Well Area .............. 2-11

2.1.4.6 Source Area 6 - Helicopter Pad and Storage Area ........ 2-15

2.1.5 Source Area 1 - Surface Ground Zero $\ldots \ldots \ldots \ldots \ldots \ldots \ldots \ldots \ldots \ldots \ldots \ldots \ldots \ldots$

2.1.5.1 AOC 1-A Station 1-A Shot Cavity ............... 2-15

2.1.5.2 AOC 1-B Beaver Pond ...................... 2-17

2.1.5.3 AOC 1-C Half Moon Creek Overflow Pond .......... 2-17

2.1.5.4 AOC 1-D Postshot No. 1 Slush Pit and "Mouse Hole" ..... 2-17

2.1.6 Source Area 2 - Northern Disposal Area ................. 2-17

2.1.6.1 AOC 2-A - Reynolds Electrical \& Engineering Co.. Inc.

Disposal Pits .......................... 2-17

2.1.6.2 AOC 2-B Debris Disposal Pits ............... 2-18 


\section{Table of Contents (Continued)}

2.1.6.3 AOC 2-C Clean Burn Pit $\ldots \ldots \ldots \ldots \ldots \ldots \ldots \ldots . . \ldots \ldots .2-18$

2.1.6.4 AOC, 2-D Refueling Pump .................... 2-19

2.1.7 Source Area 3 - Southern Storage Area .................... 2-19

2.1.7.1 AOC 3-A Mud Storage Area ..................... 2-19

2.1.7.2 AOC 3-B Big Chief Drilling Storage Area .............. 2-19

2.1.7.3 AOC 3-C E-2 and E-7 Drilling Locations .............. 2-19

2.1.7.4 AOC 3-D Government Storage Area 1 .............. 2-19

2.1.7.5 AOC 3-E Government Storage Area $2 \ldots \ldots \ldots \ldots \ldots . .2-20$

2.1.7.6 AOC 3-F Sewage Disposal Tank ................... 2-20

2.1.8 Source Area 4 - Western Disposal Area $\ldots \ldots \ldots \ldots \ldots \ldots \ldots \ldots .2-20$

2.1.8.1 AOC 4-A Reserve Mud Pits ................... 2-20

2.1.8.2 AOC 4-B Debris Disposal Pit .................. 2-21

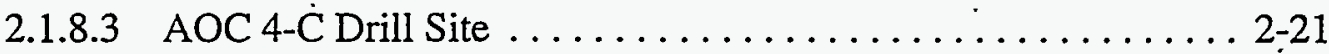

2.1.9 Source Area 5 - Injection Well Area ................... 2-21

2.1.10 Source Area 6 - Helicopter Pad and Storage Area ............. 2-22

2.1.11 Other Engineered Structures $\ldots \ldots \ldots \ldots \ldots \ldots \ldots \ldots \ldots \ldots \ldots .2-22$

2.2 Physical Setting $\ldots \ldots \ldots \ldots \ldots \ldots \ldots \ldots \ldots \ldots \ldots \ldots \ldots \ldots \ldots \ldots \ldots \ldots \ldots \ldots \ldots, 22$

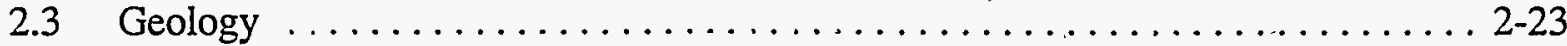

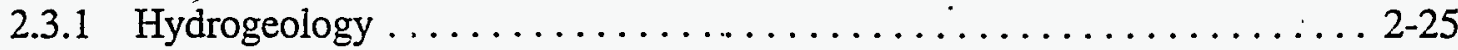

2.3.1.1 Local Hydrogeologic Regime ................. 2-26

2.3.1.1.1 Uppermost Aquifers .................... 2-26

2.3.1.1.2 Miocene Aquifer System (Local Aquifer and

Aquifers 1. 2a, 2b, 3a; and Caprock Aquifer) ...... 2-27

2.3.1.1.3 Oligocene Aquifer System (Aquifer 4) . . . . . . . 2-30

2.3.1.1.4 Eocene Hydrostratigraphic Units (Aquifer 5) . . . . . 2-31

2.3.2 Surface Water $\ldots \ldots \ldots \ldots \ldots \ldots \ldots \ldots \ldots \ldots \ldots \ldots \ldots \ldots \ldots \ldots \ldots \ldots, 2-31$

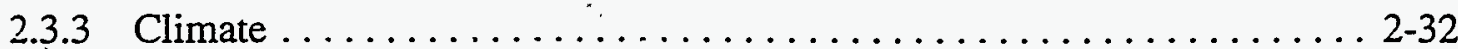

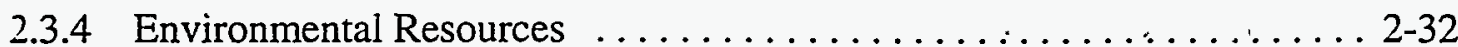

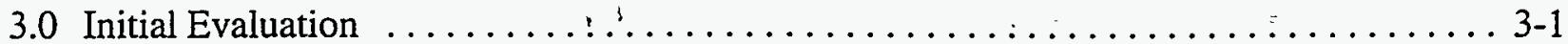

3.1 Introduction $\ldots \ldots \ldots \ldots \ldots \ldots \ldots \ldots \ldots \ldots \ldots \ldots \ldots \ldots \ldots \ldots \ldots \ldots \ldots \ldots \ldots, 1$

3.2 Known and Potential Contamination $\ldots \ldots \ldots \ldots \ldots \ldots \ldots \ldots \ldots \ldots \ldots \ldots \ldots \ldots .2$

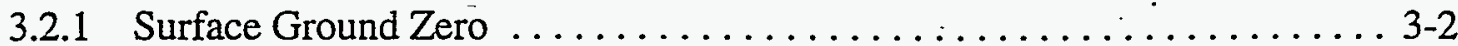




\section{Table of Contents (Continued)}

3.2.1.1 AOC 1-A, Station 1-A Shot Cavity $\ldots \ldots \ldots \ldots \ldots \ldots \ldots .3-2$

3.2.1.2 AOC 1-B, Beaver Pond ...................... 3-2

3.2.1.3 AOC 1-C, Half Moon Creek Overflow Pond ............ 3-3

3.2.1.4 AOC 1-D, Postshot No. 1 Slush Pit and "Mouse Hole" ....... 3-3

3.2.1.5 AOC 1-E, Bleed-Down Plant Area ................ 3-6

3.2.1.6 AOC 1-F, East Substation ................... 3-6

3.2.1.7 AOC 1-G, E-14 Pad and Associated Mud Pit ........... 3-6

3.2.1.8 AOC 1-H, E-6 Decontamination Pad .............. 3-7

3.2.1.9 AOC 1-I, Postshot No. 2 Mud Pit ................ 3-8

3.2.1.10 AOC 1-J, E-3/E-9 Drill Site (New AOC) . . . . . . . . . 3-8

3.2.2 Source Area 2 - Northern Disposal Area ................... 3-8

3.2.2.1 AOC 2-A, Reynolds Electrical \& Engineering Co.. Inc.

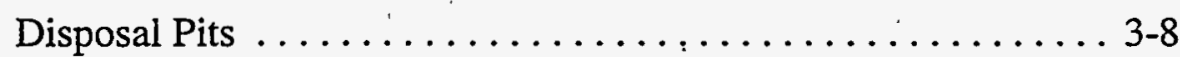

3.2.2.2 AOC 2-B, Debris Burial Pits $\ldots \ldots \ldots \ldots \ldots \ldots \ldots \ldots . . \ldots \ldots \ldots \ldots .9 .9$

3.2.2.3 AOC 2-C, Clean Burn Pits $\ldots \ldots \ldots \ldots \ldots \ldots \ldots \ldots \ldots . . \ldots \ldots \ldots .11$

3.2.2.4 AOC 2-D, Fueling Station (Gas Pump) $\ldots \ldots \ldots \ldots \ldots \ldots$ 3-11

3.2.3 Source Area 3 - Southern Storage Area .................. 3-11

3.2.3.1 AOC 3-A, Mud Storage Pits/South Barrow Pit ......... 3-11

3.2.3.2 AOC 3-B, Big Chief Drilling Storage Area ........... 3-12

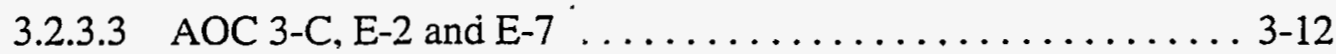

3.2.3.4 AOC 3-D, Government Storage Area 1 (Drill Storage Yard) .. 3-12

3.2.3.5 AOC 3-E, Government Storage Area $2 \ldots \ldots \ldots \ldots \ldots . . .14$

3.2.3.6 AOC 3-F, Sewage Disposal Tank (New AOC) …...... 3-14

3.2.3.7 AOC 3-G, WP 4/Station 4 Drilling Site (New AOC) ........ 3-14

3.2.4 Source Area 4 - Western Disposal Area .................. 3-14

3.2.4.1 AOC 4-A, Reserve Mud Pit(s) ................ 3-14

3.2.4.2 AOC 4-B, Debris Burial Pit $\ldots \ldots \ldots \ldots \ldots \ldots \ldots \ldots . .6 \ldots \ldots \ldots \ldots .15$

3.2.4.3 AOC 4-C, West Substation ................... 3-15

3.2.4.3.1 AOC 4-D, CH Fuel Storage Area .......... 3-15

3.2.4.3.2 AOC 4-E, Cable Storage Area $\ldots \ldots \ldots \ldots \ldots . . .17$

3.2.4.3.3 AOC 4-F, South Substation $\ldots \ldots \ldots \ldots \ldots \ldots .3-17$

3.2.4.3.4 AOC 4-G, North Substation .............. 3-17

3.2.4.3.5 AOC 4-H, E-5 Mud Pits (New AOC) ......... 3-17 
3.2.4.4 Source Area 5 - Injection Well Area ................ 3-18

3.2.4.4.1 AOC 5-A, Well HT-2 $\ldots \ldots \ldots \ldots \ldots \ldots \ldots .3-18$

3.2.4.4.2 AOC 5-B, Well HT-2m . .............. 3-18

3.2.4.5 Source Area 6 - Helicopter Pad and Storage Area ....... 3-18

3.2.5 Environmental Media Operable Units . ................ 3-21

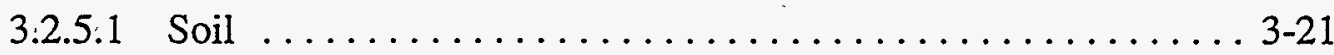

3.2.5.1.1 E-6 Decontamination Pad ............... 3-21

3.2.5.1.2 E-14 Equipment Storage $\mathrm{Pad} \ldots \ldots \ldots \ldots \ldots .3-21$

3.2.5.1.3 Bleed-Down Plant ................... 3-22

3.2.5.1.4 Drilling Equipment Storage Yard $\ldots \ldots \ldots \ldots \ldots .3-22$

3.2.5.1.5 East Parking Lot and Swamp . ............. 3-22.

3.2.5.1.6 South Road Swamp Area $\ldots \ldots \ldots \ldots \ldots \ldots . .23$

3.2.5.1.7 Additional AOC $\ldots \ldots \ldots \ldots \ldots \ldots \ldots . \ldots .23$

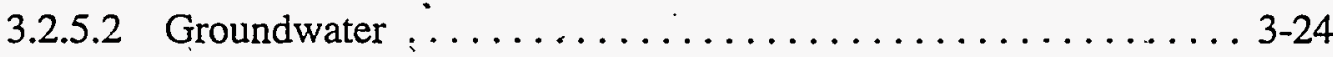

3.2.5.3 Surface Water and Sediment $\ldots \ldots \ldots \ldots \ldots \ldots \ldots \ldots \ldots \ldots \ldots \ldots \ldots \ldots \ldots$

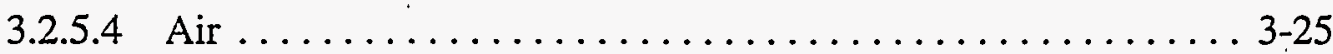

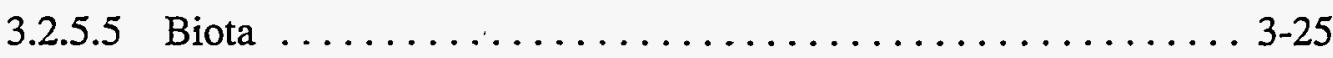

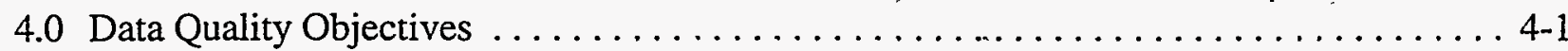

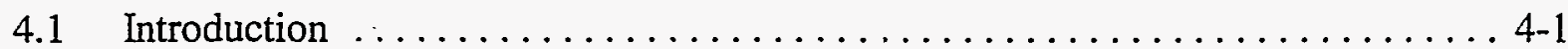

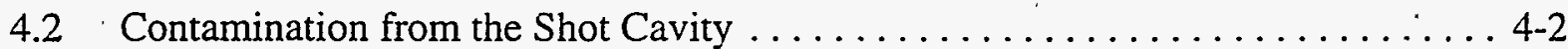

4.2.1 Problem Statement ............................ 4-2

4.2 .2 Identification of the Decision $\ldots \ldots \ldots \ldots \ldots \ldots \ldots \ldots \ldots \ldots \ldots, 4-2$

4.2.3 Design for Obtaining Data $\ldots \ldots \ldots \ldots \ldots \ldots \ldots \ldots \ldots \ldots \ldots, 4-3$

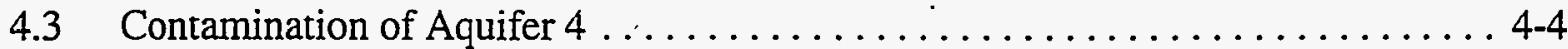

4.3.1 Statement of Problem ............................ 4-4

4.3.2 Identification of the Decision $\ldots \ldots \ldots \ldots \ldots \ldots \ldots \ldots \ldots \ldots \ldots, 4$

4.3.3 Design for Obtaining Data $\ldots \ldots \ldots \ldots \ldots \ldots \ldots \ldots \ldots \ldots \ldots, 4.4$

4.4 Source Area 2; AOC 2-A: Contamination at the Reynolds Electrical \&

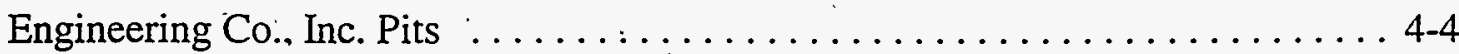

4.4.1 Statement of the Problem .......................... 4-4

4.4.2 Identification of the Decision ......................... 4-5

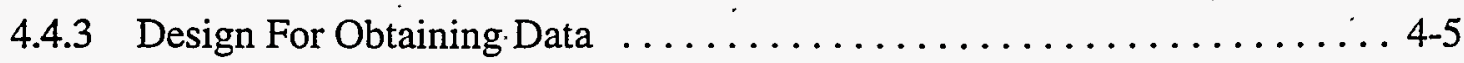




\section{Table of Contents (Continued)}

4.5 Tritium at Surface Ground Zero $\ldots \ldots \ldots \ldots \ldots \ldots \ldots \ldots \ldots \ldots \ldots \ldots$

4.5.1 Statement of Problem . . . . . . . . . . . . . . . .

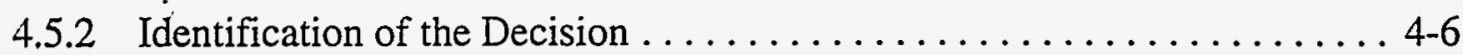

4.5.3 Design for Obtaining Data $\ldots \ldots \ldots \ldots \ldots \ldots \ldots \ldots \ldots \ldots \ldots$

4.6 Chromium in Aquifer 3 at Surface Ground Zero . . . . . . . . . . . . 4-6

4.6.1 Statement of Problem . . . . . . . . . . . . . . . . . . .

4.6.2 Identification of the Decision $\ldots \ldots \ldots \ldots \ldots \ldots \ldots \ldots \ldots \ldots \ldots \ldots \ldots \ldots$

4.6.3 Design for Obtaining Data . . . . . . . . . . . . . . . . $4-7$

4.7 Pentachlorophenol in the Caprock Aquifer $\ldots \ldots \ldots \ldots \ldots \ldots \ldots \ldots \ldots \ldots .7$

4.7.1 Statement of the Problem . . . . . . . . . . . . . . . . . . .

4.7 .2 Identification of the Decision $\ldots \ldots \ldots \ldots \ldots \ldots \ldots \ldots \ldots \ldots \ldots \ldots$

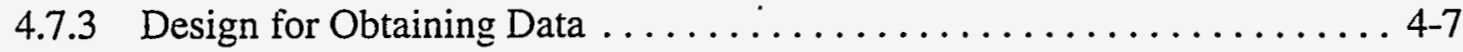

4.8 Tritium in the Mud Storage Pits $\ldots \ldots \ldots \ldots \ldots \ldots \ldots \ldots \ldots \ldots \ldots \ldots \ldots$

4.8.1 Statement of the Problem ..................... 4-8

4.8.2 Identification of the Decision $\ldots \ldots \ldots \ldots \ldots \ldots \ldots \ldots \ldots \ldots \ldots \ldots$

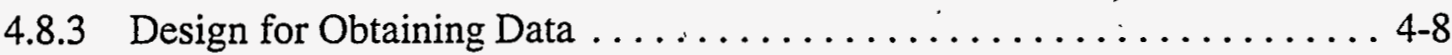

4.9 Tritium in Disposal Pit 5 Area $\ldots \ldots \ldots \ldots \ldots \ldots \ldots \ldots \ldots \ldots \ldots \ldots$

4.9.1 Statement of the Problem . . . . . . . . . . . . . . . . . . 4

4.9.2 Identification of the Decision $\ldots \ldots \ldots \ldots \ldots \ldots \ldots \ldots \ldots \ldots \ldots$

4.9.3 Design for Obtaining Data $\ldots \ldots \ldots \ldots \ldots \ldots \ldots \ldots \ldots \ldots \ldots \ldots \ldots \ldots$

4.10 Possible Contamination in the Clean Burn Pit (Source Area 2) . . . . . . . . 4-9

4.10.1 Statement of the Problem . . . . . . . . . . . . . . . . . . 4-9

4.10 .2 Identification of the Decision $\ldots \ldots \ldots \ldots \ldots \ldots \ldots \ldots \ldots \ldots .4 .9$

4.10.3 Design for Obtaining Data . . . . . . . . . . . . . . . . 4

4.11 Possible Chromum in Soil from HM-3 Purge Water . . . . . . . . . . . . 4-9

4.11.1 Statement of the Problem . . . . . . . . . . . . . . . . . 4-9

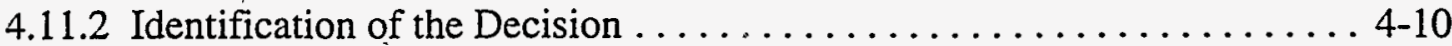

4.11 .3 Design for Obtaining Data . . . . . . . . . . . . . . . 4-10

4.12 Possible Contamination from Drilling Fluids at the E-5 Well Location . . . . . 4-10

4.12.1 Statement of the Problem . . . . . . . . . . . . . . . . . . . 4-10

4.12.2 Identification of the Decision . . . . . . . . . . . . . . . 4-10

4.12.3 Design for Obtaining Data . . . . . . . . . . . . . . . . 4-10

4.13 Possible Contamination from Drilling Fluids at the E-3/E-9 Well Location . . . . 4-10 


\section{Table of Conitents (Continued)}

4.13.1 Statement of the Problem . . . . . . . . . . . . . . . .

4.13 .2 Identification of the Decision $\ldots \ldots \ldots \ldots \ldots \ldots \ldots \ldots \ldots \ldots \ldots \ldots \ldots$

4.13.3 Design for Obtaining, Data . . . . . . . . . . . . . . 41

4.14 Possible Contamination from Drilling Fluids at the Station 3 and

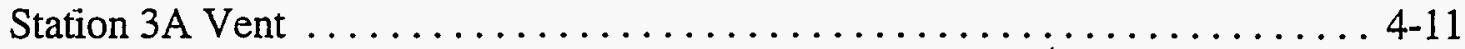

4.14.1 Statement of the Problem . . . . . . . . . . . . . . . . . 4-11

4.14.2 Identification of the Decision $\ldots \ldots \ldots \ldots \ldots \ldots \ldots \ldots \ldots \ldots \ldots \ldots \ldots \ldots$

4.14.3 Design for Obtaining Data ... . . . . . . . . . . . . . 4-11

4.15 Possible Contamination from Drilling Fluids at the E-2/E-7 Well Locations . . . 4-12

4.15 .1 Statement of the Problem . . . . . . . . . . . . . . $\ldots \ldots \ldots$ 42

4.15 .2 Identification of the Decision $\ldots \ldots \ldots \ldots \ldots \ldots \ldots \ldots \ldots \ldots \ldots \ldots \ldots \ldots \ldots \ldots \ldots .12$

4.15.3 Design for Obtaining Data . . . . . . . . . . . . . . 4-12

4.16 Possible Contamination from Drilling Fluids at the W.P. 4 and Station 4

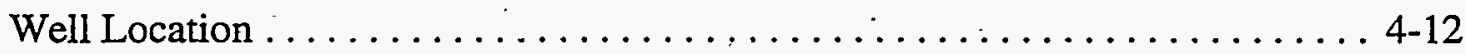

4.16.1 Statement of the Problem ..................... 4-12

4.16 .2 Identification of the Decision . . . . . . . . . . . . . . . . 4-12

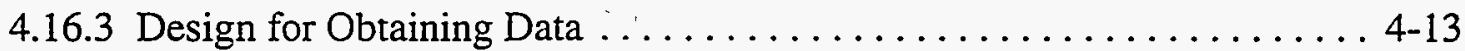

4.17 Potential Contamination from a Sewage Disposal System near Government

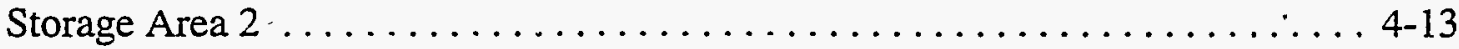

4.17.1 Statement of the Problem $\ldots \ldots \ldots \ldots \ldots \ldots \ldots \ldots \ldots \ldots \ldots \ldots \ldots \ldots \ldots \ldots \ldots .13$

4.17 .2 Identification of the Decision $\ldots \ldots \ldots \ldots \ldots \ldots \ldots \ldots \ldots \ldots \ldots \ldots \ldots \ldots$

4.17.3 Design for Obtaining Data $\ldots \ldots \ldots \ldots \ldots \ldots \ldots \ldots \ldots \ldots \ldots \ldots \ldots \ldots \ldots$

5.0 Remedial Investigation Tasks $\ldots \ldots \ldots \ldots \ldots \ldots \ldots \ldots \ldots \ldots \ldots \ldots \ldots \ldots \ldots \ldots \ldots$

5.1 Detailed Site Characterization $\ldots \ldots \ldots \ldots \ldots \ldots \ldots \ldots \ldots \ldots \ldots \ldots \ldots .1$

5.1.1 Shallow and Deep Groundwater Monitor Well Installation . . . . . . . 5-1

5.1.2 Source Area 1 - Surface Ground Zero . . . . . . . . . . . . 5-2

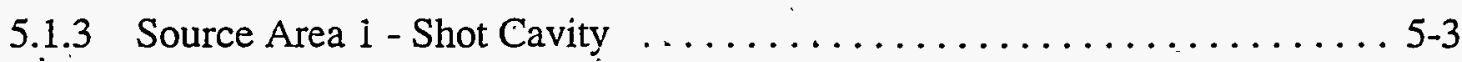

5.1.4 Source Area 2 - Reynolds Electrical \& Engineering Co., Inc.

Disposal Pits ....................... 5-3

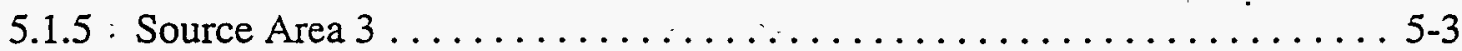

5.1.5.1 Source Area 3 - Mud Storage Area (Pits) . . . . . . . . . . . . 5-7

5.1.5.2 Source Area 3 - Station 4 and W.P. 4 Drilling Sites . . . . . . . 5-7 


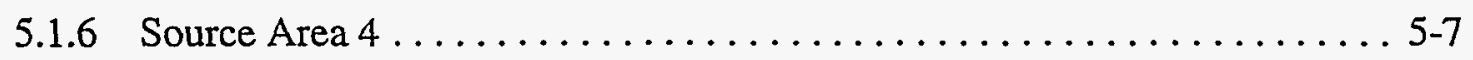

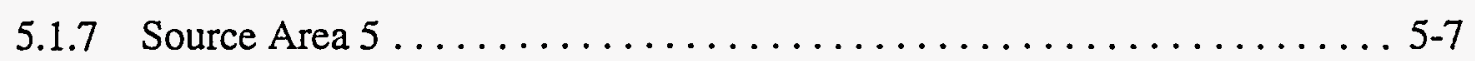

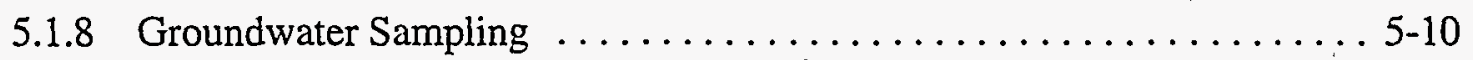

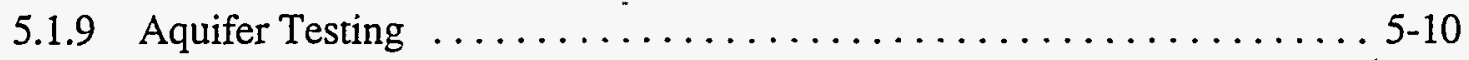

5.1 .10 Geophysical Investigation $\ldots \ldots \ldots \ldots \ldots \ldots \ldots \ldots \ldots \ldots \ldots \ldots \ldots \ldots \ldots \ldots \ldots .11$

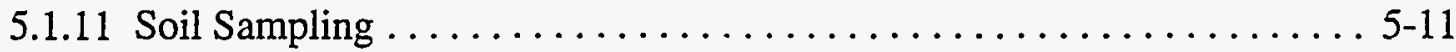

5.1.12 Test Pit Excavation and Drum Sampling ............... 5-12

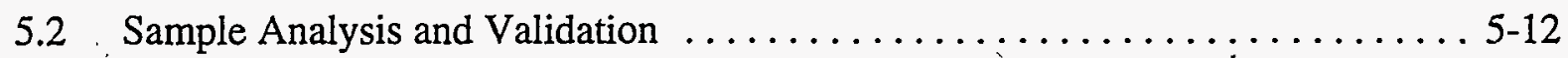

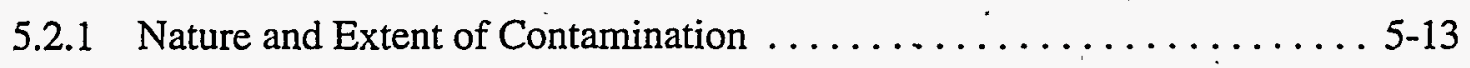

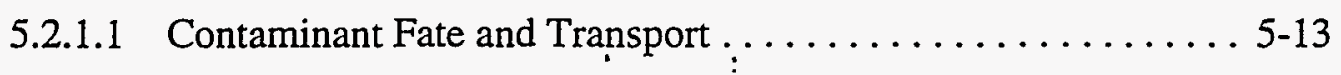

5.2.2 Human Health and Environmental Risk Assessment $\ldots \ldots \ldots \ldots \ldots . . \ldots$ 5-15

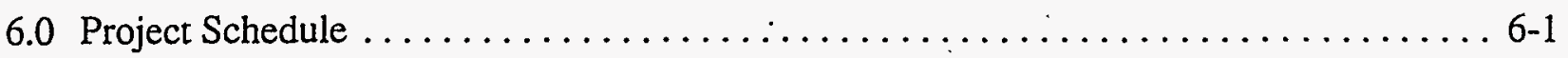

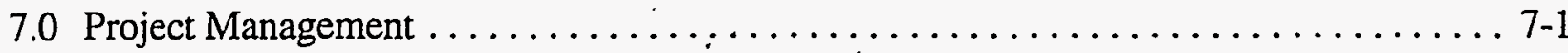

7.1 Management Organization and Responsibilittes $\ldots \ldots \ldots \ldots \ldots \ldots \ldots \ldots .1$

7.1.1 DOE Headquarters ............................ $7-1$

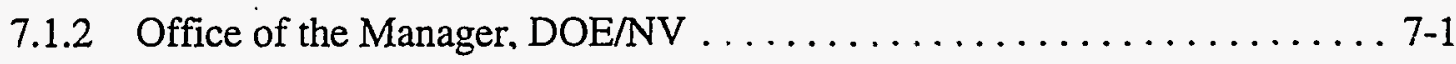

7.1.2.1 Assistant Manager for Environmental Restoration and Waste

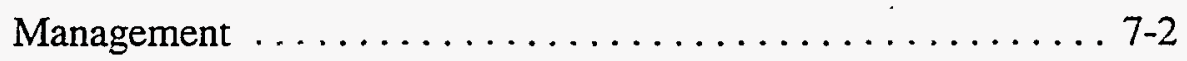

7.1.2.2 Environmental Restoration Division ............... 7-2

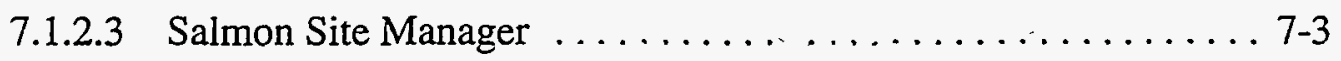

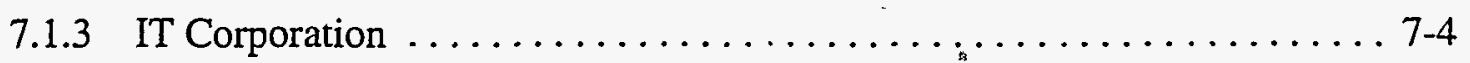

7.1.4 U.S. Environmental Protection Agency ................... 7-5

8.0 References $\ldots \ldots \ldots \ldots \ldots \ldots \ldots \ldots \ldots \ldots \ldots \ldots \ldots \ldots \ldots \ldots \ldots . .6 .1$ 


\section{List of Figures}

Number

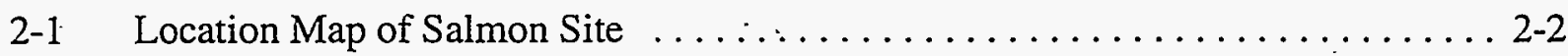

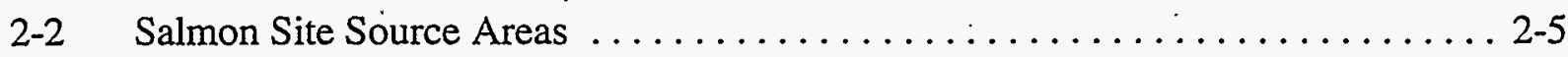

2-3 Areas of Concern in Source Area $1 \ldots \ldots \ldots \ldots \ldots \ldots \ldots \ldots \ldots . . .2-9$

2-4 Areas of Concern in Source Area $2 \ldots \ldots \ldots \ldots \ldots \ldots \ldots \ldots \ldots \ldots \ldots \ldots \ldots \ldots \ldots .10$

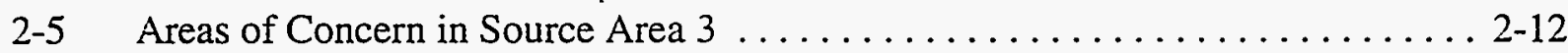

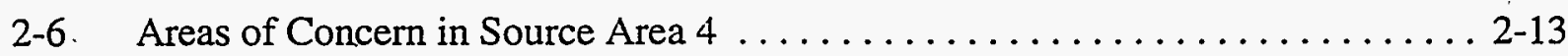

2-7 Areas of Concern in Source Area $5 \ldots \ldots \ldots \ldots \ldots \ldots \ldots \ldots \ldots \ldots \ldots \ldots \ldots \ldots \ldots \ldots .14$

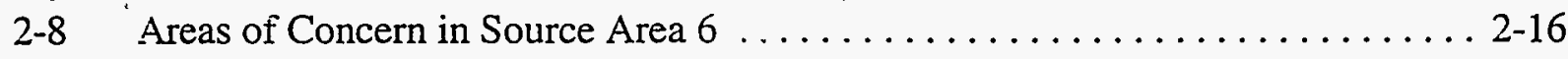

3-1 Location of Half Moon Creek Alluvial Aquifer Monitor Wells in the Vicinity of Surface Ground Zero $\ldots \ldots \ldots \ldots \ldots \ldots \ldots \ldots \ldots \ldots \ldots$

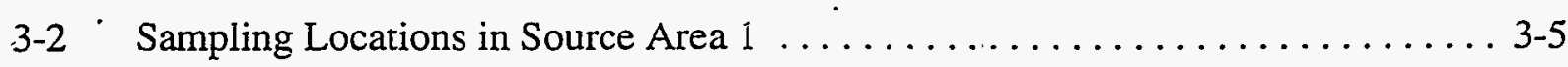

3-3 Sampling Locations in Source Area $2 \ldots \ldots \ldots \ldots \ldots \ldots \ldots \ldots \ldots \ldots \ldots \ldots \ldots$

3-4 Sampling Locations in Source Area $3 \ldots \ldots \ldots \ldots \ldots \ldots \ldots \ldots \ldots \ldots \ldots \ldots$

3-5 Sampling Locations in Source Area $4 \ldots \ldots \ldots \ldots \ldots \ldots \ldots \ldots \ldots \ldots \ldots \ldots$

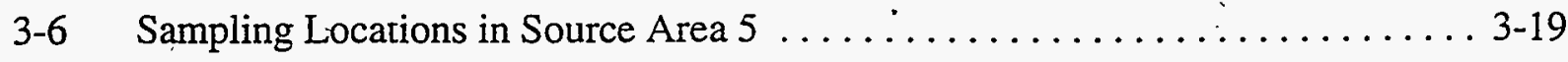

3-7 Sampling Locations in Source Area $6 \ldots \ldots \ldots \ldots \ldots \ldots \ldots \ldots \ldots \ldots \ldots \ldots \ldots \ldots \ldots \ldots$ 
5-1 Planned Monitoring Well and Soil Boring Locations in Source Area $1 \ldots \ldots$. . . 5-4

5-2 Planned Monitoring Well and Soil Boring Locations in Source Area $2 \ldots \ldots$. . . 5-5

5-3 Planned Monitoring Well and Soil Boring Locations in Source Area $3 \ldots$. . . . 5-6

5-4 Planned Monitoring Well and Soil Boring Locations in Source Area $4 \ldots \ldots$. . . 5-8

5-5 Planned Monitoring Well and Soil Boring Locations in Source Area $5 \ldots$. . . 5-9

6-1 Anticipated Schedule for Completion of the Salmon Site

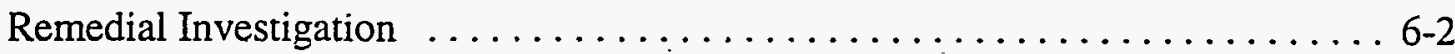




\section{List of Tables}

Number

Title

Page

2-1 List of Source Areas, Individual Sites, and Potential Contamination Sources for the Salmon Site, Lamar County, MS $2-6$

3-1 Sampling and Survey Activities Completed at the Salmon Site, Lamar County, Mississippi

4-1 Existing and Proposed Wells for the Surface Ground Zero Area by Aquifer . . . . 4-3

4-2 Nonradioactive Water and Soil Analyses Constituents of Concern (All 1988 Organics and 1990 Metals) $4-14$

4-3 Radionuclide List for Gamma Spectroscopy $4-15$

5-1 Planned Groundwater Monitoring Wells Salmon Site $5-2$

5-2 Planned Soil Borings Listed by Site $5-11$

6-1. Major Milestones for the Salmon Site RI/FS Project $6-1$ 


\begin{tabular}{|c|c|}
\hline ADS & Activity Data Sheet \\
\hline AEC & U.S. Atomic Energy Commission \\
\hline AMEM & $\begin{array}{l}\text { Assisstant Manager for Environmental Restoration and Waste } \\
\text { Management }\end{array}$ \\
\hline AOC & Area of Concern \\
\hline CERCLA & Comprehensive Environmental Response, Compensation and Liability Act \\
\hline $\begin{array}{l}\text { CLP } \\
\mathrm{cm}\end{array}$ & Contract Laboratory Program \\
\hline $\mathrm{COC}$ & $\begin{array}{l}\text { centimeter } \\
\text { constitutent of concern }\end{array}$ \\
\hline $\mathrm{CPT}$ & Cone Penetrometer Testing \\
\hline CRDL & Contract Required Detection Limit \\
\hline DOE/HQ & U.S. Department of Energy Headquarters \\
\hline DOE & U.S. Department of Energy \\
\hline $\mathrm{DOE} / \mathrm{NV}$ & U.S. Department of Energy, Nevada Operations Office \\
\hline DQO & data quality objective \\
\hline $\mathrm{EE}$ & Environmental Evaluation \\
\hline EEW & Environmental Evaluation Work Plan \\
\hline EPA & U.S. Environmental Protection Agency \\
\hline FS & Feasibility Study \\
\hline $\mathrm{ft}$ & foot \\
\hline gal & gallon \\
\hline $\mathrm{gpd} / \mathrm{ft}$ & gallon per day per foor \\
\hline HASP & Health and Safety Plan \\
\hline HHRA & Human Health Risk Assessment \\
\hline HMCAA & Half Moon Creek Alluvial Aquifer \\
\hline $\begin{array}{l}\text { in. } \\
\text { IT }\end{array}$ & $\begin{array}{l}\text { inch } \\
\text { IT Corporation }\end{array}$ \\
\hline $\begin{array}{l}\text { IT } \\
\mathrm{km}\end{array}$ & $\begin{array}{l}\text { IT Corporation } \\
\text { kilometer }\end{array}$ \\
\hline $\mathrm{km}^{2}$ & square kilometer \\
\hline € & liter. \\
\hline LLD & lowest level of detection \\
\hline $\begin{array}{l}\text { LTHMP } \\
\mathrm{m}\end{array}$ & $\begin{array}{l}\text { Long-Term Hydrologic Monitoring Program } \\
\text { meter }\end{array}$ \\
\hline $\mathrm{m}^{2}$ & cubic meter \\
\hline MCL & Maximum Contaminant Level \\
\hline MDA & Minimum Detectable Activity \\
\hline $\mathrm{mi}$ & $\begin{array}{l}\text { mile } \\
\text { square mile }\end{array}$ \\
\hline $\begin{array}{l}\mathrm{mi}^{2} \\
\mathrm{MS}-\mathrm{DEQ}\end{array}$ & $\begin{array}{l}\text { square mile } \\
\text { Mississippi Department of Environmental Quality }\end{array}$ \\
\hline MS-DOH & $\begin{array}{l}\text { Mississippi Department of Environmental Quality } \\
\text { Mississippi Department of Health }\end{array}$ \\
\hline NEPA & National Environmental Policy Act \\
\hline NPL & National Priorities List \\
\hline
\end{tabular}




$\begin{array}{ll}\text { NTS } & \text { Nevada Test Site } \\ \text { NV ERP } & \text { Nevada Environmental Restoration Project } \\ \text { PCB } & \text { polychlorinated biphenyl. } \\ \text { pCi/l } & \text { picocurie per liter } \\ \text { PCTDD } & \text { Project Control and Technology Development Division } \\ \text { PMP } & \text { Project Management Plan } \\ \text { ppm } & \text { part per million } \\ \text { QA/QC } & \text { quality assurance and quality control } \\ \text { QAPP } & \text { Quality Assurance Project Plan } \\ \text { REECo } & \text { Reynolds Electrical \& Engineering Co., Inc. } \\ \text { RI/FS } & \text { Remedial Investigation and Feasibility Study } \\ \text { RI } & \text { Remedial Investigation } \\ \text { SAP } & \text { Sampling and Analysis Plan } \\ \text { SGZ } & \text { Surface Ground Zero } \\ \text { SS } & \text { Salmon Site } \\ \text { SDWA } & \text { Safe Drinking Water Act } \\ \text { TDS } & \text { total dissolved solid } \\ \text { USGS } & \text { U.S. Geological Survey } \\ \text { WMD } & \text { Waste Management Division } \\ \text { yd } & \text { cubic yard } \\ { }^{\circ} \mathrm{C} & \text { degree Celsius } \\ { }^{\circ} \mathrm{F} & \text { degree Fahrenheit }\end{array}$




\subsection{Introduction}

\subsection{Purpose and Scope of the Remedial Investigation and Feasibility Study}

This document is intended as an addendum to the Remedial Investigation and Feasibility Study (RI/FS) Work Plan for the Salmon Site (SS) (formerly the Tatum Dome Test Site) Lamar County, Mississippi. The original work plan - Remedial Investigation and Feasibility Study of the Tatum Dome Test Site, Lamar County, Mississippi (DOE, 1992) (herein after called the Work Plan) was approved by the state of Mississippi in 1992 and was intended as the operative document for investigative activities at the Tatum Dome Test Site. Subsequent to the approval of the document a series of activities were undertaken under the auspices of the work plan. This document is organized in the same manner as the original work plan: (1) Introduction; (2) Site Background and History; (3) Initial Evaluation; (4) Data Quality Objectives; (5) RI/FS Tasks; (6) Project Schedule (7) Project Management: and (8) Reference. This addendum will identify changes to the original work plan that are necessary because of additional information acquired at the SS. This document is not intended to replace the work plan, rather, it is intended to focus the remaining work in the context of additional site knowledge gained since the development of the original work plan.

The U.S. Department of Energy (DOE) is conducting a focused and phased site characterization as a part of the RI/FS. The RI/FS is the methodology under the Comprehensive Environmental Response. Compensation and Liability Act (CERCLA) for evaluating hazardous waste sites on the National Priorities List (NPL). The SS is not listed on the NPL, but DOE has voluntarily elected to conduct the evaluation of the SS in accordance with CERCLA.

\subsection{Project Goals}

The goals of this RI/FS for the SS are to provide adequare and appropriate site characterization data for conducting a risk assessment to evaluate existing and future exposures, and to develop and evaluate a range of remedial alternatıves in the Feasibility Study (FS). It is anticipated the risk assessment will focus on future land use scenarios that will determine continued restricted use or an unrestricted future use of the site.

\subsection{Work Plan Organization}

Excepted as noted herein, the organization of this addendum is the same as for the original Work Plan. 


\subsection{Quality Assurance}

The RI/FS Work Plan and its supporting project plans (i.e., the Quality Assurance Project · Plan [QAPP], the Sampling and Analysis Plan [SAP], Health and Safety Plan [HASP], the Project Management Plan [PMP], and the Data Management Plan) have been developed to meet identified U.S. Environmental Protection Agency (EPA) and DOE guidelines. This Work Plan is not intended to be a state document. It, or any of its supporting plans. is subject to revision as necessary to maintain the overall objectives of the RI/FS. Subsequent to the approval of the Work Plan, a series of Standard Operating Procedures were adopted by DOE-for use by the Nevada Environmental Restoration Project. Where applicable, these have been incorporated by reference into this Addendum. 


\subsection{Site Background and Setting}

The SS has been extensively investigated as a result of DOE activities at the site and monitoring by various state and federal agencies, and more recently, contractors. The information avarlable comprises an extensive database which covers the operation of the site, its history, and its present physical setting. These topics are discussed in detail in the Work Plan and are summarized in the following sections. Information acquired subsequent to the issuance of the original plan is also presented.

\subsection{Site Description}

\subsubsection{Location}

The SS is located in south-central Mississippi about 32 kilometers $(\mathrm{km})$ (20 miles [mi]) southwest of the Hattiesburg. A general location map of the site is shown in Figure 2-1. The site property encompasses approximately 595 hectares (1,470 acres) in Sections 11, 12, 13, and 14 of Township 2 North, Range 16 West, St. Stephens Meridian. Access to within $1.6 \mathrm{~km}$ (1 mi) of the site is via U.S. Highway 11 and other paved county roads. A network of graded gravel roads provides access to various locations on the site.

The SS was the location for two nuclear and two gas explosion tests conducted deep underground in the Tatum Salt Dome. These tests, conducted between 1964 and 1970, were part of the U.S. Atomic Energy Commission's (AEC) Vela Uniform Program which was conducted to improve the United States' ability to detect. identify, and locate underground nuclear detonations. The SS is owned and managed by the U.S. Department of Energy, Nevada Operations Office (DOE/NV). Surface Ground Zero (SGZ), the ground surface point directly above the location where nuclear testing was conducted. is at latitude $31^{\circ} 08^{\prime} 32^{\prime \prime}$ north. longitude $89^{\circ} 34^{\prime} 12^{\prime \prime}$ west. A granite monument now marks the location of SGZ.

\subsubsection{History of Operations}

A complete history of the SS prior to 1990 is given in Section 2.1.2 of the original Work Plan (DOE, 1992). Those activities conducted subsequent to the issuance of the Work Plan are summarized below:

- June 1992 - Submission of the Work Plan.

- July 1992 - Initiation of National Environmental Policy Act (NEPA) surveys 


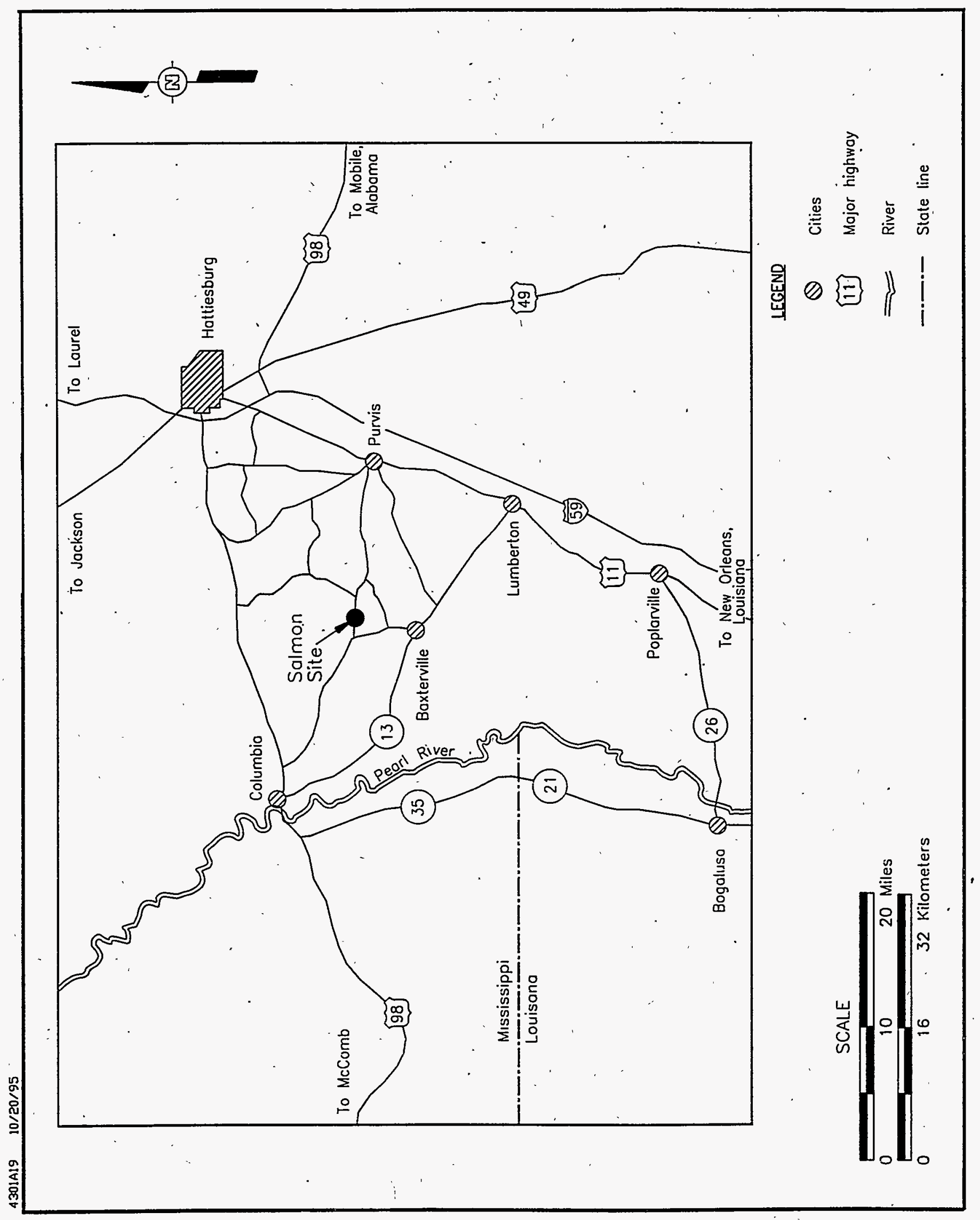

Figure 2-1

Location Map of Salmon Site 
- September 1992 - State approval of the Work Plan

- October 1992 - Gopher Tortoise Survey

- November 1992 - Initial surface geophysics

- February 1993 - Sample Collection: surface water, sediments, biota

- April - May 1993 - Soil, Vegetation and Groundwater-Sampling; continuation of the geophysical survey

- August 1993 - January 1994 - Construction activities: completion of the Geophysical surveys, Cone Penetrometer Testing and sampling, Trench Excavations and soil sampling

- December 1994 - The DOE purchases the SS from private land owner

- Continued Long-Term Hydrologic Monitoring Program (LTHMP).

\subsubsection{Waste Generation Processes}

A wide variety of activities took place at the SS during testing of both nuclear and gas explosives that resulted in the generation of wastes. Following each of the testing events. reentry holes were drilled into the detonation cavity to determine the subsurface effects of each explosion. These drilling operations generated the largest single volume of waste materials. including radioactively contaminated drill cuttings, and drilling fluids.

Wastes other than radioactively contaminated materials were also generated as part of the testing operations. Nuclear testing is a major undertaking that requires the combined efforts of a large team of workers and a full range of service facilities. During site operation, the SS had a work force of more than 100 people. The operation of the test site required fuel. electricity, sanitation, and waste disposal. as well as the storage and use of hazardous materials on site.

Most of these wastes and contaminated soil and water were picked up and disposed of either in the cavity left by the tests. in an on-site injection well or were removed from the site. The injection well was used following the two nuclear tests to dispose of liquid wastes. During the 1972 decommissioning of the site, additional clean-up and waste removal operations were conducted. The equipment was decontaminated and transported to the Nevada Test Site (NTS) for disposal. Nonradioactive wastes were disposed of in pits at the site. which were subsequently backfilled with clean soil and graded. The site was relatively inactive from 1972 to 1992. 
Following the decommissioning of the site several additional issues were raised by concerned citizens. the state of Mississippi, and congressional leaders. In response to these concerns, the DOE initiated a series of studies that culminated in the issuance of a work plan for conducting a CERCLA-type investigation at the SS. A complete summary of the activities at the site, prior to the issuance of the 1992 Work Plan, can be found in the original work plan.

\subsubsection{Source Areas}

Based upon the nature of the SS and the types of activities conducted at the SS. six areas designated as Source Areas have been defined (Figure 2-2). The general characteristics and rational for defining the source areas are discussed in this section. Table 2-1 lists the individual Areas of Concern (AOC) within each source area. The general operational characteristics of each site, dimensions, dates, status, and the references that were used in compiling the source area descriptions are given in the original Work Plan in Table 2-2.

\subsubsection{Source Area 1 - Surface Ground Zero}

Surface Ground Zero encompasses a number of sites where soil and/or groundwater contamination is known or suspected. The individual AOC within this source area include the Station 1-A Shot Cavity within the salt dome and Mud-Pit. Beaver Pond, Half Moon Creek Overflow Pond, the Postshot No. 1 Slush Pit and Mouse. Hole, the former Bleed-Down Plant Area, the East Substation, the E-14 Pad and Mud Pits. Postshot No. 2 Mud Pit, and the E-6 . Decontamination Pad. With the exception of the Shot Cavity, all of these sites are at the surface. A map showing the AOC within Source Area 1 is provided in Figure 2-3.

These sites were included in a single source area because of their geographic proximity on the west side of Half Moon Creek and the nature of activities that were conducted at the sites.

\subsubsection{Source Area 2 - Northern Disposal Area}

The Northern Disposal Area encompasses all former waste disposal sites on the east side of Half Moon Creek, including the Reynolds Electrical \& Engineering Co.. Inc. (REECo) Disposal Pits (noncombustible material disposal areas and the borrow and disposal area), the Debris Burial Pit, the Clean Burn Pit and the former vehicle fueling pump location. A map showing the AOC within Source Area 2 is provided in Figure 2-4. These AOC were included in a single source area because of the similar types of waste disposal activities conducted at the site. their geographical proximity, and their location on the east side of Half Moon Creek, which places them in a slightly different hydrogeologic setting than other source areas. The groundwater flow in the uppermost aquifer underlying this Source Area is suspected to be primarily to 
poos pasosdu!un

poos pososdw

Комцб!!

ONבปรT

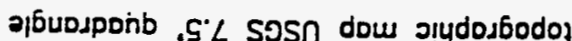

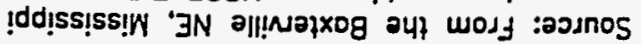

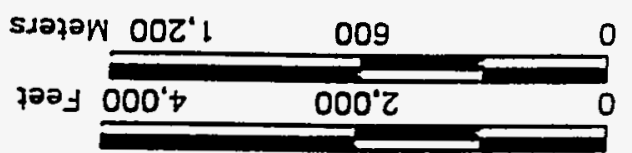

Эาษว

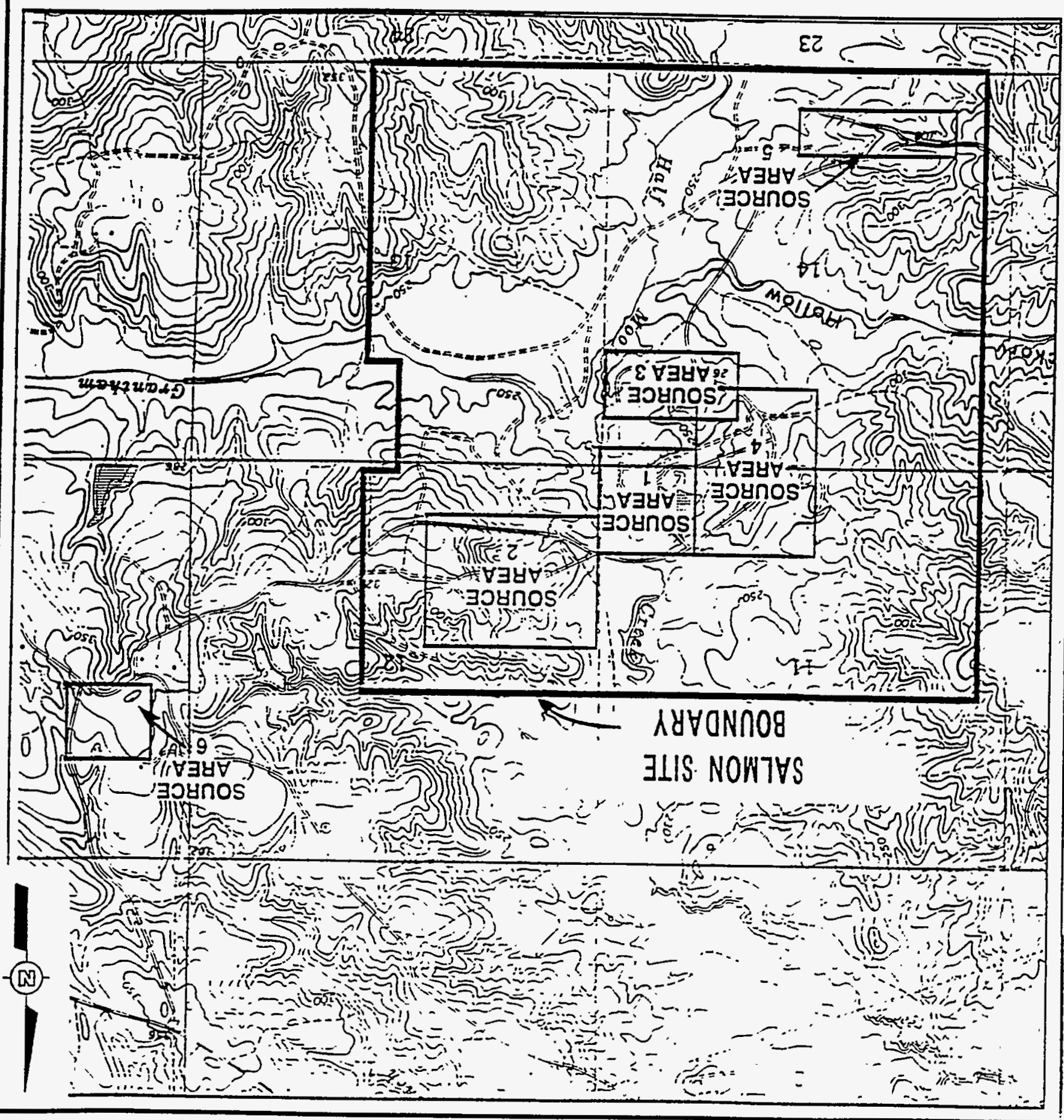


Table 2-1

List of Source Areas, Individual Sites, and

Potential Contamination Sources for the Salmon Site, Lamar County, MS

(Page 1 of 3 )

\begin{tabular}{|c|c|c|c|c|}
\hline \multicolumn{2}{|c|}{ Source Area Description } & $A_{O C}{ }^{a}$ No. & Site Name & Contaminants of Concern \\
\hline \multirow[t]{9}{*}{ 1. Surface Ground Zero (SGZ) } & \multirow[t]{9}{*}{$\ddots$} & $1-A$ & Station 1-A.Shot Cavily and Mud Pit & $\begin{array}{l}\text { Lead from shielding materials, synthetic } \\
\text { materials used in cables, residuals from } \\
\text { stemming materials. }\end{array}$ \\
\hline & & $1-\mathrm{B}$ & Beaver Pond & Tritium, fuels, and drilling fluids. \\
\hline & & $2-C$ & Half Moon Creek Overflow Pond & Tritium. \\
\hline & & $1-D$ & $\begin{array}{l}\text { Postshot No. } 1 \text { Slush Pit and Mouse } \\
\text { Hole }\end{array}$ & Tritium, radionuclides, and drilling fluids. \\
\hline & & $1-E$ & Bleed-Down Plant Areà & $\begin{array}{l}\text { Possible residual radioactive contamination from } \\
\text { radioactive gas treatment plant. }\end{array}$ \\
\hline & & $1-F$ & East Substation & $\begin{array}{l}\text { Potential contamination by } \mathrm{PCBs}^{\mathrm{b}} \text { and generator } \\
\text { fuel. }\end{array}$ \\
\hline & & $1-G$ & E-14 pad and Mud Pits & $\begin{array}{l}\text { Residual radioactive contamination from } \\
\text { equipment storage and drilling fluids. }\end{array}$ \\
\hline & & $1-H$ & E-6 Decontamination Pad & $\begin{array}{l}\text { Residual radioactive contamination from } \\
\text { equipment decontamination rinsate. }\end{array}$ \\
\hline & & $1-1$ & Postshot No. 2 Mud Pit & $\begin{array}{l}\text { Contamination of the shallow aquifer by drilling } \\
\text { fluids, tritium, and fuels. }\end{array}$ \\
\hline \multirow{4}{*}{\multicolumn{2}{|c|}{ 2. Northern Disposal Area }} & $2-A$ & REECo, Disposal Pits & $\begin{array}{l}\text { Tritium, materials of unknown - presumed } \\
\text { nonradioactive-composition. }\end{array}$ \\
\hline & & $2-B$ & Debris Burial Pit & $\begin{array}{l}\text { Materials of unknown - presumed nonradioactive } \\
\text { - composition. }\end{array}$ \\
\hline & & $2-C$ & Clean Burn Pit & $\begin{array}{l}\text { Motor oils, solvents and other unknown } \\
\text { materials. }\end{array}$ \\
\hline & & 2-D & Gas Station & Possible fuel spills and leakage of UST. \\
\hline
\end{tabular}

Refer to footnotes at end of table. 
Table 2-1

List of Source Areas, Individual Sites, and

Potential Contamination Sources for the Salmon Site, Lamar County, MS

(Page 2 of 3 )

\begin{tabular}{|c|c|c|c|}
\hline Source Area Description & AOC $^{\mathrm{a}}$ No. & Site Name & Contaminants of Concern \\
\hline \multirow[t]{7}{*}{ 3. Southern Storage Area } & $3-A$ & Mud Storage Pits/South Bòrrow Pit & $\begin{array}{l}\text { Possible organics, metals, and tritium } \\
\text { contamination. }\end{array}$ \\
\hline & 3-B & Big Chief Drilling Storage Area & $\begin{array}{l}\text { Fuel and hydraulic equipment spills and storage } \\
\text { of drill equipment. }\end{array}$ \\
\hline & $3-\mathrm{C}$ & Site: E-2 and E-7 & $\begin{array}{l}\text { Contamination from drilling fluids (metals and } \\
\text { diesel) and tritium. Recent sampling indicated } \\
\text { the presence of Pentachlorophenol in the E-7 } \\
\text { well. }\end{array}$ \\
\hline & 3-D & $\begin{array}{l}\text { Government Storage Area } 1 \text { (drilling } \\
\text { storage) }\end{array}$ & $\begin{array}{l}\text { Possible tritium contamination from the storage } \\
\text { of contaminated drilling equipment. }\end{array}$ \\
\hline & 3-E & Government Storage Area 2 & Unknown materials - presumed nonradioactive. \\
\hline & $3-F$ & Sewage disposal tank & Unknown wastes. \\
\hline & $3-G$ & Station 4 and W.P. 4 Drilling Sites & $\begin{array}{l}\text { Drilling fluids contaminated with metals and } \\
\text { diesel. }\end{array}$ \\
\hline \multirow[t]{6}{*}{ 4. Western Disposal Area } & $4-A$ & Reserve Mud Pits & $\begin{array}{l}\text { Contamination by drilling fluids (metals } \\
\text { organics). }\end{array}$ \\
\hline & 4-B & Debris Burial Pit & Disposal of unknown materials. \\
\hline & $4-C$ & West Substation & $\begin{array}{l}\text { Potentially contaminated by PCB and generator } \\
\text { fuel. }\end{array}$ \\
\hline & 4-D & CH Fuel Storage Area & Possible fuel spills. \\
\hline & $4-E$ & Cable Storage Area & $\begin{array}{l}\text { Possible contamination by residual products } \\
\text { from burned cable. }\end{array}$ \\
\hline & $4-F$ & South Substation & $\begin{array}{l}\text { Potentially contaminated by PCB and generator } \\
\text { fuel. }\end{array}$ \\
\hline
\end{tabular}

Refer to footnotes at end of table. 
Table 2-1

List of Source Areas, Individual Sites, and

Potential Contamination Sources for the Salmon Site, Lamar County, MS

(Page 3 of 3 )

\begin{tabular}{|c|c|c|c|}
\hline Source Area Description & AOC $^{\mathrm{a}}$ No. & Site Name & Contaminants of Concern \\
\hline \multirow[t]{2}{*}{ Western Disposal Area (continued) } & $4-G$ & North Substation & $\begin{array}{l}\text { Potentially contaminated by PCB and generator } \\
\text { fuel. }\end{array}$ \\
\hline & $4-H$ & E-5 Drill Site & $\begin{array}{l}\text { Contamination by drilling fluids (metals and } \\
\text { organics). }\end{array}$ \\
\hline \multirow[t]{2}{*}{ 5. Injection Well Area } & $5-A$ & Well HT-2 & $\begin{array}{l}\text { Radiological contaminants resulting from } \\
\text { injection operations of waste into Aquifer } 5 \text {. } \\
\text { Integrity of plug in well is suspect. }\end{array}$ \\
\hline & $5-B$ & Well HT-2m & $\begin{array}{l}\text { Radiological contaminants resulting from } \\
\text { injection operations of waste into Aquifer } 5 \text {. } \\
\text { Integrity of plug in well is suspect. }\end{array}$ \\
\hline 6. Helicopter Pad and Storage Area & $6-A$ & Helicopter Pad and Storage Area & Possible fuel spills. \\
\hline
\end{tabular}

${ }_{\text {A Area of Concein }}$

Polychlorinated Biphenyl 


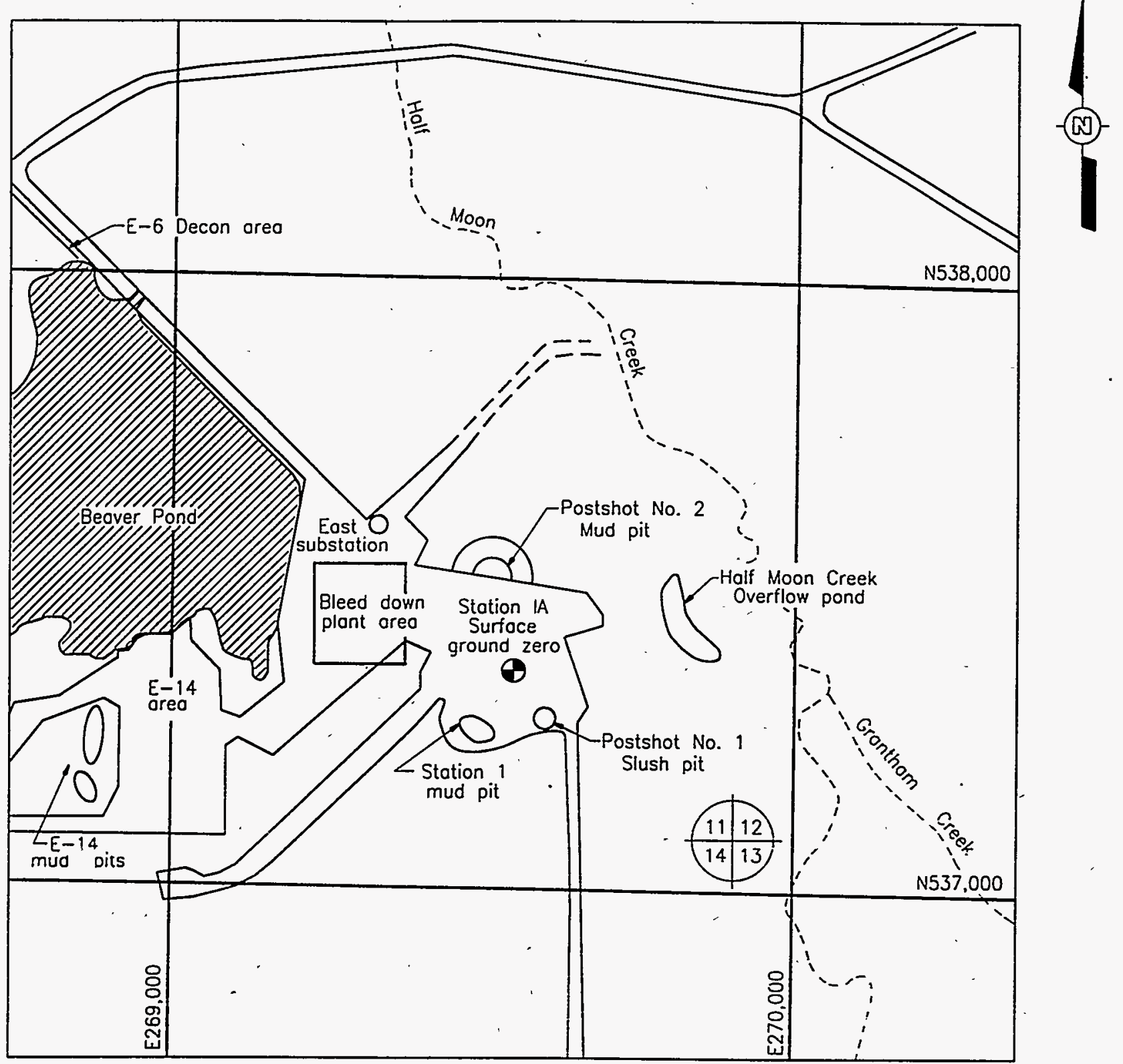

Mississippi State Planor Coordinates

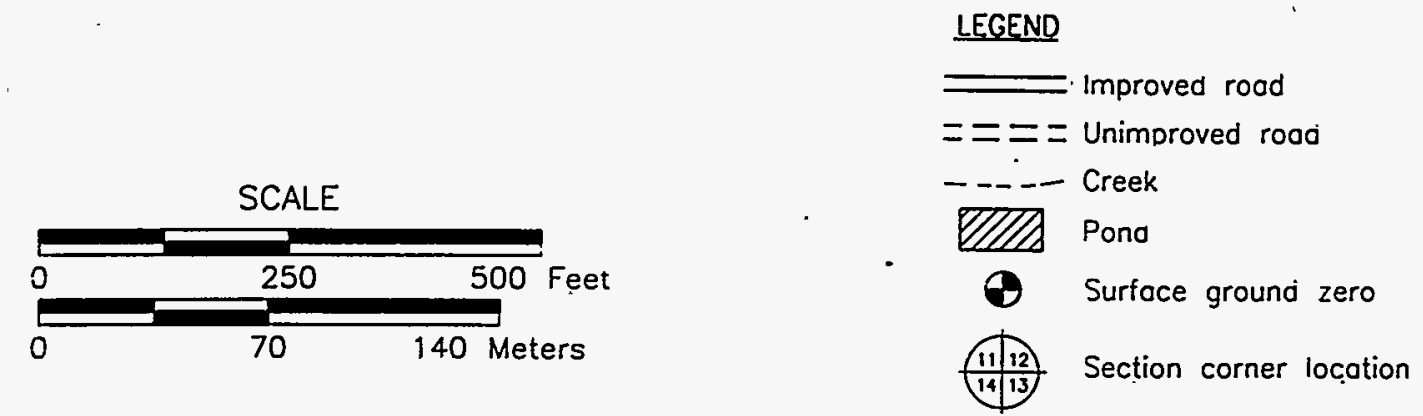

Figúre 2-3

Areas of Concern in Source Area 1 


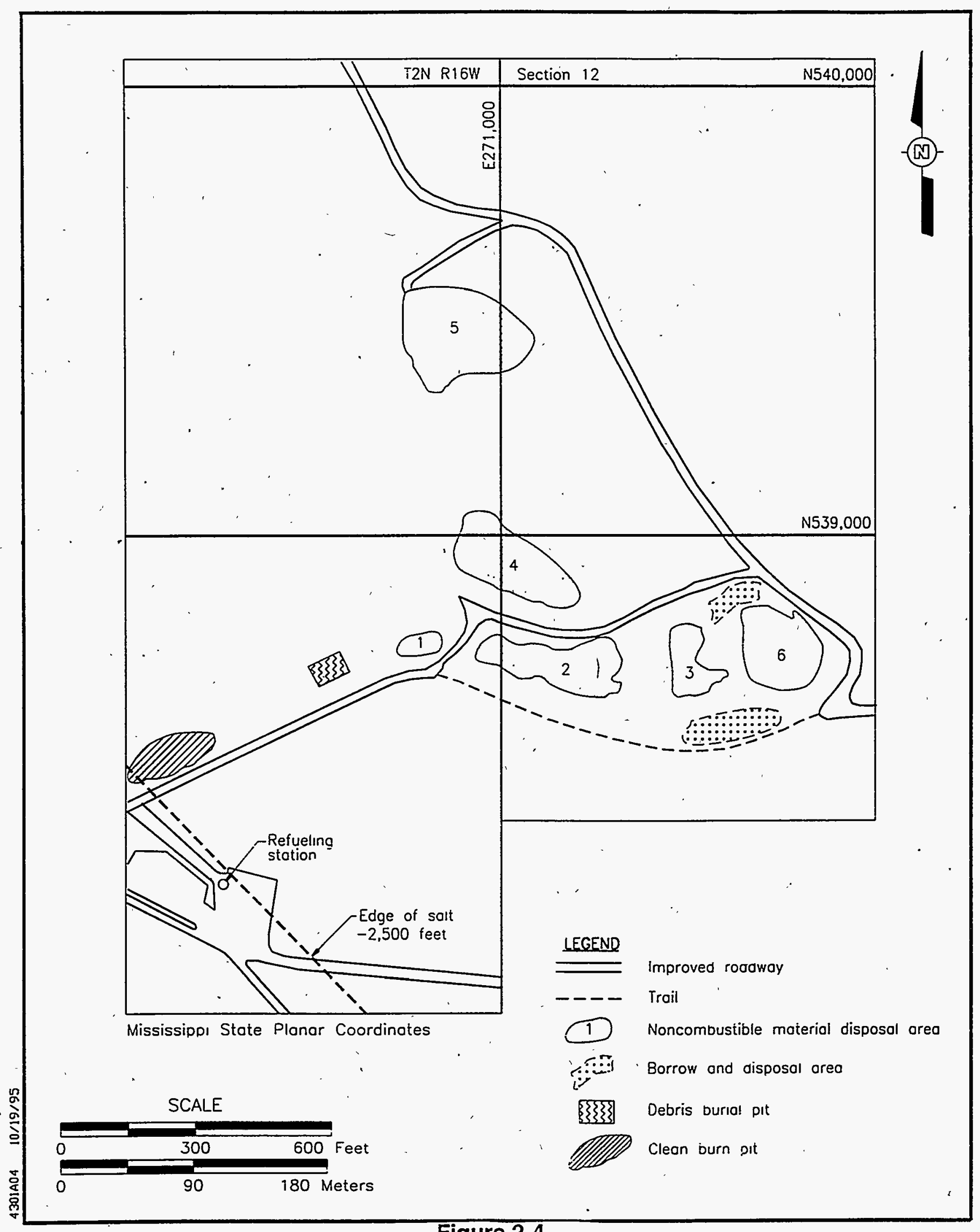

Figure 2-4

Areas of Concern in Source Area 2 
the west, unlike the other source areas, where flow in the uppermost aquifer is primarily to the east.

\subsubsection{Source Area 3 - Southern Storage Area}

The Southern Storage Area encompasses the Mud Storage Pits/South Borrow Pit. the Big Chief Drilling Storage Area, Government Storage Area 1, Government Storage Area 2. and Sites E-2 and E-7. Subsequent to the original Work Plan, a possible sewage disposal tank near Government Storage Area 1 has been identified. Additionally, drilling mud pits associated with I the drilling of the Station 4 and WP-4 wells may present another potential source of contamination. A map showing the AOC within Source Area 3 is provided in Figure 2-5. These AOC were included in a single source area because of the similar type of operations conducted at the sites (storage rather than disposal), their geographic proximity, and the inferred easterly flow of groundwater in the uppermost aquifer.

\subsubsection{Source Area 4 - Western Disposal Area}

- The Western Disposal Area encompasses the Reserve Mud Pits, the Debris Burial Pit, the North. West, and South Substations, the CH Fuel Storage Area. and the Cable Storage Area. A map showing the AOC within Source Area 4 is provided in Figure 2-6. These AOC were included in a single source area because of their geographic proximity and because the nature of the AOC indicates that the radionuclide contaminants that are the primary concern at Source Area 1 (SGZ) are probably not present at these sites. A Salt Disposal Area had originally been included in Source Area 4; however. information provided by the Mississippi Department of Environmental Quality (MS-DEQ) indicated that this disposal area. although once planned. was never actually constructed (MS-DEQ, 1991). As a consequence, this AOC has been removed from further consideration. One additional $\mathrm{AOC}$ has been identified in this source area. subsequent to the issuance of the original Work Plan: an abandoned drilling mud pit near the site of the E-5 Well may contain residual contamination from drilling fluids.

\subsubsection{Source Area 5 - Injection Well Area}

The Injection Well Area is of limited extent encompassing the former injection well HT-2, the former monitoring well HT-2m, and the area in the vicinity of these wells where surficial contamination may have resulted during site operations and decommissioning. Based upon information provided by the MS-DEQ, a drilling mud pit was also associated with injection well HT-2 (MS-DEQ, 1991). Because of the proximity of these injection wells to a local drainage, residual contamination from drilling fluids may be present in the drainage. 


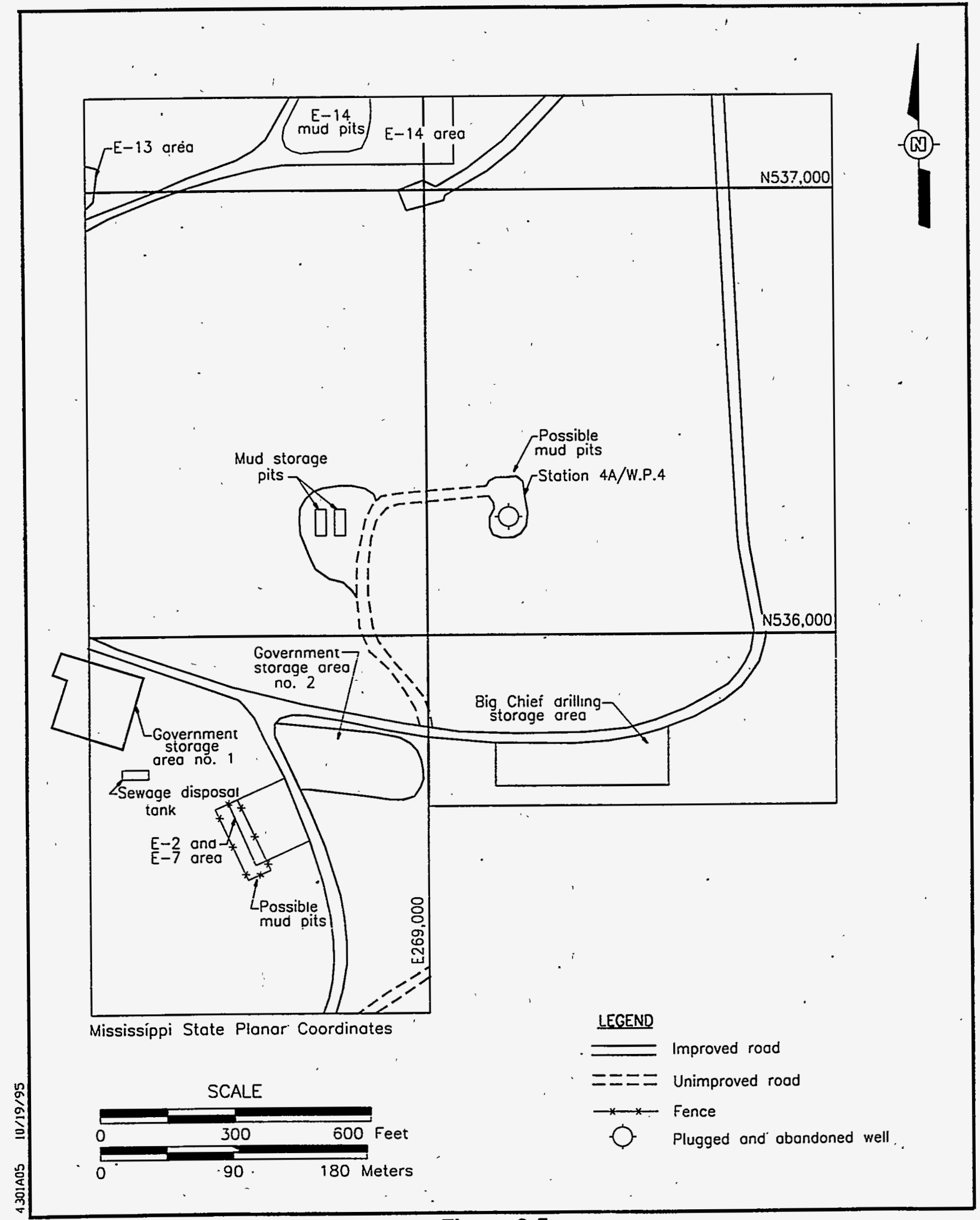

Figure 2-5

Areas of Concern in Source Area 3 


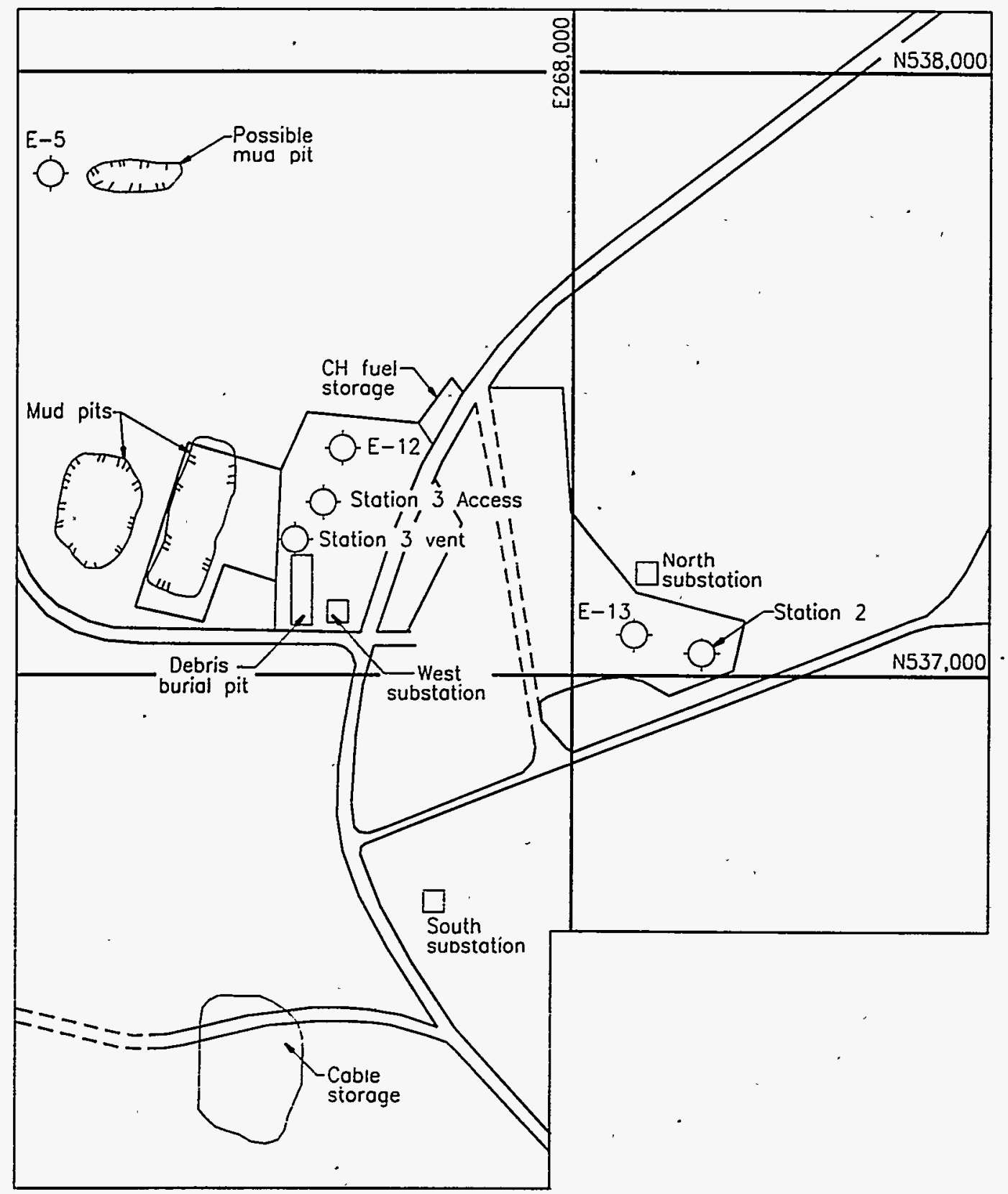

Mississippi State Planar Coordinates

SCALE

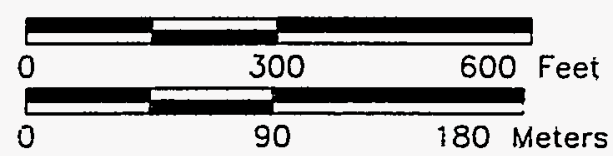

LEGEND

= Improved road

ニニニニ Unimproved rood

Plugged and abandoned well

Figure 2-6

Areas of Concern in Source Area 4 


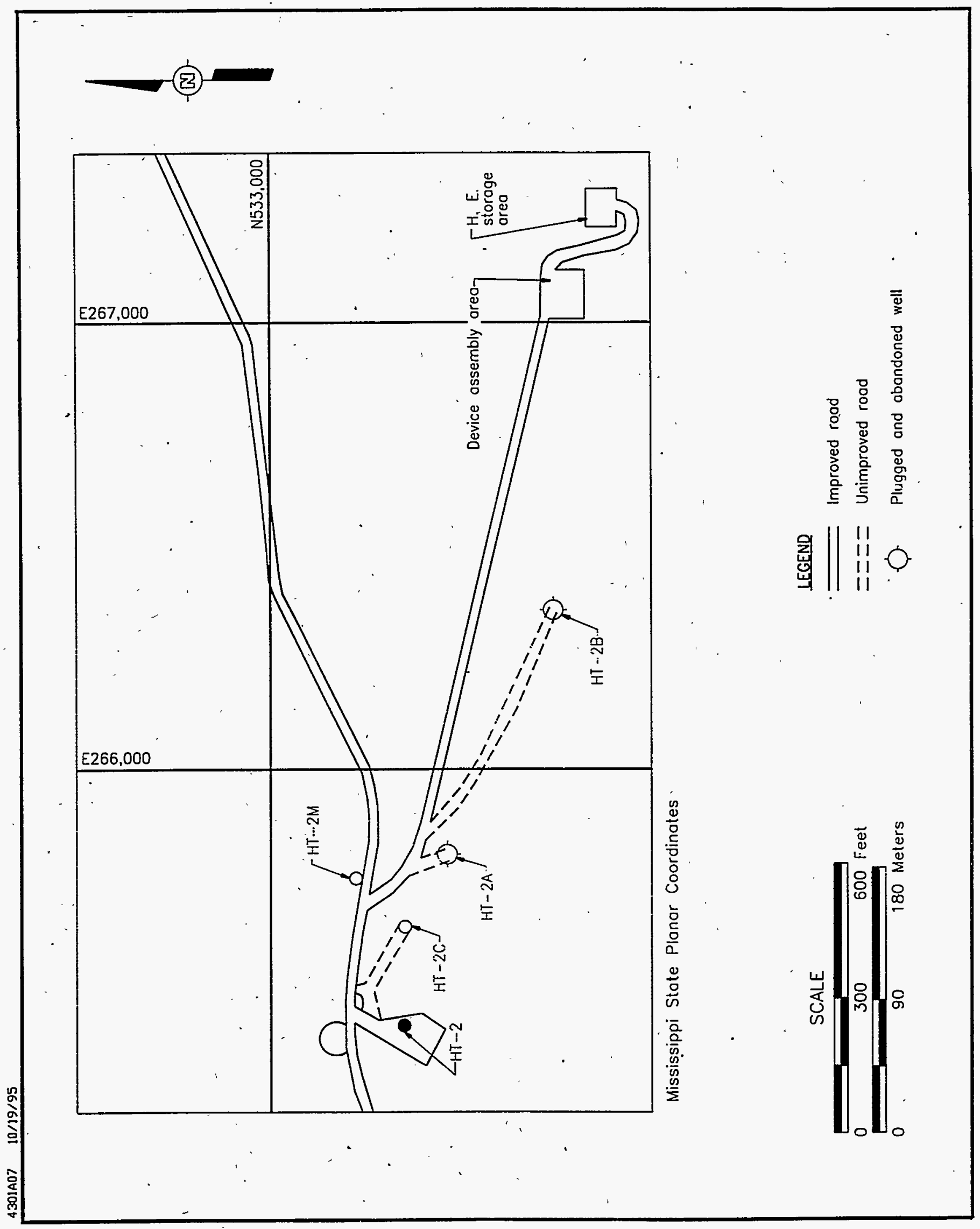

Figure 2-7

Areas of Concern in Source Area 5 
A map showing the AOC within Source Area 5 is provided in Figure 2-7. These AOC were included as a single source area because of the nature of waste disposal at the sites (deep well disposal) and geographic separation from the other source areas.

\subsubsection{Source Area 6 - Helicopter Pad and Storage Area}

The Helicopter Pad and Storage Area is also of limited extent, encompassing only the former landing site to the northeast of the SS. A map of the Source Area is provided in Figure 2-8. This site was included as a source area because of its remoteness from other source areas and the unique activities that were conducted at the site.

\subsubsection{Source Area 1 - Surface Ground Zero}

Source Area 1 is located around SGZ and includes 9 AOC (Table 2-1). The SAP, which includes the Field Sampling Plan and Environmental Evaluation Work Plan (EEW), is designed to investigate each of these sites to determine if contaminants are present. Based on their proximity, these $A O C$ can be grouped into four functional areas: (1) SGZ that consists of Station 1A Shot Cavity and Mud Pit, Postshot No. 1 slush pit, Half Moon Creek Overflow Pond. the Bleed-down plant area. the east substation, and Postshot No. 2.mud pit; (2) The Beaver Pond; (3) the E-6 decon area; and (4) the E-14 drilling pad and mud pits.

The waste disposal activities conducted at each of the sub-sites are summarized below.

\subsubsection{AOC 1-A Station 1-A Shot Cavity}

The Station 1-A Shot Cavity is located under SGZ and includes both the cavity formed by the Salmon Event and the Station 1-A reentry boring that was drilled into the cavity following the detonation. Figure 2-11 of the original Work Plan schematically represents the cavity and locations of the reentry holes following the Salmon Event. The cavity was also used for disposal of the soils excavated from contaminated areas. Material was transported and deposited onto a holding pad adjacent to the reentry boring. The soil was then placed in a hopper at the borehole collar via a conveyor belt. Contaminated water from various on-site tanks and clean water from Half Moon Creek was mixed with these soils to produce a slurry which was injected into the shot cavity. An estimated 10,700 cubic meters $\left(\mathrm{m}^{3}\right)\left(14,000\right.$ cubic yards $\left.\left[\mathrm{yd}^{3}\right]\right)$ of contaminated soil and water were disposed of in this manner. Following disposal. the borehole was sealed with concrete and special plugging.materials along with 10-centimeter $(\mathrm{cm})$ (4-in. [inch]) diameter steel pipe to prevent accidental drilling into the plug. 


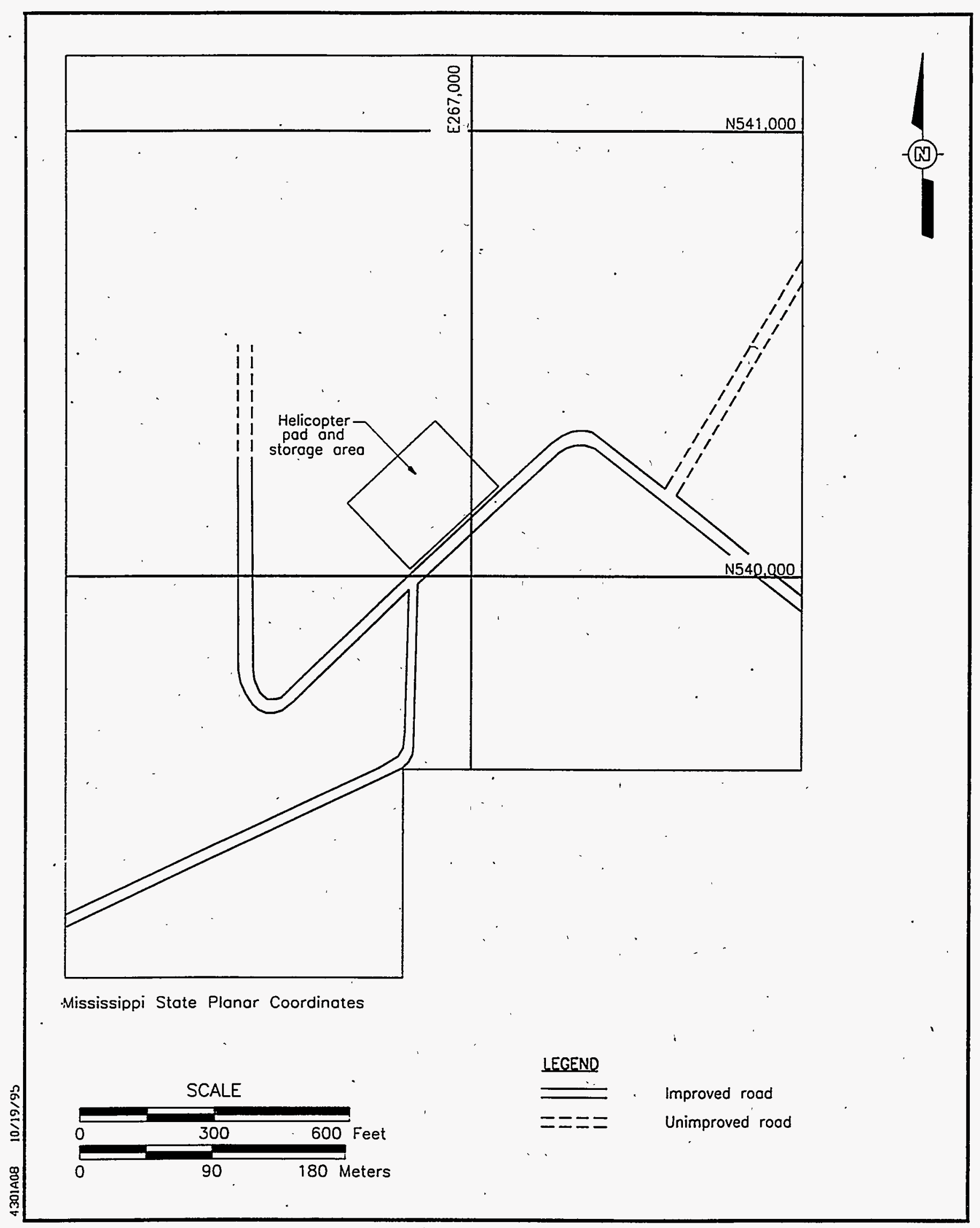

Figure 2-8

Areas of Concern in Source Area 6 


\subsubsection{AOC 1-B Beaver Pond}

The Beaver Pond resulted from the construction of a road through a marshy area. Beavers dammed the drain culverts, and the pond formed to the west of SGZ. Monitoring Well HMH-16, installed in the vicinity of the Beaver Pond and sampled in 1990, was found to contain low activity levels of tritiated groundwater.

\subsubsection{AOC 1-C Half Moon Creek Overflow Pond}

Although not intended as a waste facility, Half Moon Creek Overflow Pond has received wastewater generated as part of the monitoring program that has been ongoing at the SS since 1972. Groundwater with low tritium activity generated during purging and sampling of monitoring wells HM-S and HM-L has been discharged to the ground surface since 1979. This water drains to the Half Moon Creek Overflow Pond via natural drainage.

\subsubsection{AOC 1-D Postshot. No. 1 Slush Pit and "Mouse Hole"}

The Postshot No. 1 Slush Pit was located at the extreme southern portion of the Station 1-A area and was excavated for use as a liquid waste storage pit during the Salmon Event postshot drilling operations. The pit was filled with drilling sludge and covered with clean soil. Subsequent erosion and flooding resulted in contamination of the South Road area and the adjacent swamp. During decommissioning, the excavation of the slush pit and adjacent contaminated areas was hampered by shallow groundwater conditions. As a consequence, the cleanup standard was relaxed by the $\mathrm{AEC}$ and decommissioning was completed by backfilling the excavation with clean fill. The "Mouse Hole" was under the SGZ marker and was not used for waste disposal.

\subsubsection{Source Area 2 - Northern Disposal Area}

Source Area 2 includes a total of nine AOC; seven that were used for the disposal of solid wastes, a pit that was used to burn materials, and a former fuel station. The waste disposal activities conducted at each of the sites are summarized below.

\subsubsection{AOC 2-A - Reynolds Electrical \& Engineering Co., Inc. Disposal Pits} Six disposal pits and a borrow pit are located to the northeast of SGZ within Source Area 2, the Northern Disposal Area. This area is referred to in historic reports and maps as the REECo Disposal Area. During sire decommissioning, the pirs were used for the disposal of noncombustible materials and uncontaminated tools and equipment. An inspection of this disposal area in 1988 by the DOE and state of Mississippi personnel found that erosion of the site has occurred (Personal Communication, Dr. J. Kitchen, DOE-NV, 16 August, 1990). A headcut gully was observed at that time that was approximately 4.6 meters $(\mathrm{m})(15$ feet [ft]) deep and 
6 to $7.6 \mathrm{~m}$ ( 20 to $25 \mathrm{ft}$ ) wide. Wastes that were observed in the bottom of the gully included wire, steel, bricks, concrete slabs, and badly corroded drums. These drums, based upon information provided to the DOE by a former site guard, contain personal protection equipment, such as gloves and coveralls, which were placed in plastic bags, containerized in 76- or 113-liter ( ) (25- or 30-gallon [gal]) drums, and then disposed.of in the borrow pit; however, the material observed in the gully may only be rip rap dumped to control headcutting. Additional inspections of the area during 1993 activities at the site were unable to locate any drums or personal protection equipment.

During the 1990 inspection of the borrow pit area, a seep was observed emanating from the base of the area undergoing active headcutting. This seep was sampled (REECo Sampling Site A) and was found to contain tritium concentrations above background activities ( 890 picocuries per liter $[\mathrm{pCi} / \ell] \pm 230)($ Wruble, 1974).

A geophysical survey was conducted over the entire REECo pits during 1993 (DOE, 1994c). The results of this study indicated the presence of numerous anomalies scattered across the site. In the vicinity of the seep, the anomalies identified were attributed to the metallic surface debris (fencing, fence posts, concrete reinforcing wire, etc). Subsequent trenching activities in other areas of the pits located small quantities of metal debris related to site operations and large quantities of drilling mud disposed of in earthen pits and covered with clean fill. No buried drums were located; although, a quantity of steel and electrical cables were found (DOE, 1994b).

\subsubsection{AOC 2-B Debris Disposal Pits}

A debris disposal pit was located about $15 \mathrm{~m}$ (50 ft) west of the REECo Disposal Pits. The types of materials disposed at this site are unknown. Geophysical investigation of this site indicated the presence of several large magnetic anomalies. Subsequent trenching activities showed the anomalies to have been caused by buried steel, electrical cables, and assorted scrap metal. A portion of this site was also found to have been used for burning.

\subsubsection{AOC 2-C Clean Burn Pịt}

A burn pit was located about $150 \mathrm{~m}(500 \mathrm{ft})$ west of the REECo Disposal Pits. Because this pit was used for the incineration of nonnadioactive materials, it was referred to as the Clean Burn Pit. No information concerning the operation of this pit is available: however, such pits are commonly used for the incineration of combustible debris and spent oils and solvents. Because the Clean Burn.Pit may have been used for the disposal of ignitable hazardous wastes, it is considered a site for the Remedial Investigation (RI). 


\subsubsection{AOC 2-D Refueling Pump}

During site operations, a refueling station was located adjacent to the main road at the junction of the Sandpit Road (this site was designated "Gas Pump" in the original Work Plan). The station was most likely used to dispense gasoline and/or diesel fuel. and had an underground storage tank and possibly an above ground storage tank(s), located in close proximity. Possible contaminants at this site are lead and hydrocarbons.

\subsubsection{Source Area 3 - Southern Storage Area}

There are six individual sites located in Source Area 3. Originally only storage sites were thought to be included in Source Area 3 because no waste disposal sites are known to have been operated within this source area (DOE, 1992). The actual disposition of several sites is unknown. The Mud Storage Area may have residual drilling muds in pits and is a potential source of contamination with metals and/or trace levels of radionuclides. Several exploratory holes were drilled in the area and drilling mud pits associated with these operations may be a potential source of contamination with metals, volatile organic compounds, and hydrocarbons. · An "as-built" map produced in 1969 indicates that a sewage disposal tank was located to the southeast of Government Storage Area 1 (Holmes and Narver. 1969).

\subsubsection{AOC 3-A Mud Storage Area}

This site is locared in the northern part of Source Area 3 and it appears to have been graded during site construction. Drilling fluids were apparently stored in earthen pits at this site and it is also possible that this was the site of the drilling fluids mixing plant.

\subsubsection{AOC 3-B Big Chief Drilling Storage Area}

This site is located in the central portion of the source area, south of the main road. and was used to store drilling equipment. Potential contaminants are fuel, lubricants, and solvents used in the maintenance of the equipment.

\subsubsection{AOC 3-C E-2 and E-7 Drilling Locations}

This site is located along the road to the west gate of the site. Two exploratory wells were drilled at this site. Potential contaminants are total petroleum hydrocarbons (TPH) and heavy metals associated with drilling operations.

\subsubsection{AOC 3-D Government Storage Area 1}

This site was used to store drilling equipment. Potential contaminants are fuel. lubricants. and solvents used in the maintenance of the equipment. 


\subsubsection{AOC 3-E Government Storage Area 2}

The use and disposition of this site is unknown.

\subsubsection{AOC 3-F Sewage Disposal Tank}

This site is located southeast of Government Storage Area 2. The tank was reportedly filled and abandoned in place, but the disposition of the leech lines is unknown (AEC, 1970).

\subsubsection{Source Area 4 - Western Disposal Area}

The Western Disposal Area encompasses the Reserve Mud Pits, the Debris Burial Pit. the North, West. and South Substations, the Fuel Storage Area, and the Cable Storage Area. Two large diameter shafts were constructed along with a hoist house and warehouse (Holmes and Narver, 1969): These two shafts were designated Station 3 Access and Station 3 Vent. Station 3 Access hole was constructed to a total depth of $327 \mathrm{~m}(1,072 \mathrm{ft})$ and over-reamed to $198 \mathrm{~m}(950 \mathrm{ft})$. Construction problems caused the operation to be abandoned: A second hole, Station 3 Vent, was drilled at a location approximately $30 \mathrm{~m}(100 \mathrm{ft})$ southwest of Station 3 . The well reached a total depth of $636 \mathrm{~m}(2,087 \mathrm{ft})$ and was plugged for abandonment in 1971 (Medley, 1972). A third hole, E-12, is located $30 \mathrm{~m}$ ( $100 \mathrm{ft}$ ) northeast of Station 3 Access. The E-12 hole that reached a depth of approximately $878 \mathrm{~m}(2,882 \mathrm{ft})$ was plugged for abandonment in 1971 . These sites were included in a single source area because of their geographic proximity and because the nature of the sites indicates that the radionuclide contaminants that are the primary concern at Source Arè 1 (SGZ) are probably not present at these sites.

A Salt Disposal Area was originally included in Source Area 4: however, information provided by the MS-DEQ indicated that this disposal area, although once planned, was never actually constructed (MS-DEQ, 1991). As a consequence, this site has been removed from further consideration.

\subsubsection{AOC 4-A Reserve Mud Pits}

The location of two reserve mud pits has been identified on "as-built" diagrams (Holmes and Narver. 1969). These were identified in the original work plan as being used to mix mud for. drilling operations related to the emplacement and postshot drill-back activities: however, the relationship between the mud pits and the drill holes suggests that they were used during the drilling operations in Area 4. Although there are no data indicating that the pits were used for waste disposal, residual drilling muds may be present. The primary potential contaminants are related to the drilling fluids used in the construction of the shafts and fuels and lubricating oils used by the drilling equipment. 


\subsubsection{AOC 4-B Debris Disposal Pit}

A debris disposal pit is located about $610 \mathrm{~m}(2,000 \mathrm{ft})$ west of SGZ. This disposal area was used for the disposal of nonradioactive materials, presumably construction debris and rubbish. No information is available on this site: thus. it is unknown if any hazardous substance may have been disposed at the site.

\subsubsection{AOC 4-C Drill Site}

This site is located north of the reserve mud pits in the northwest corner of the Source Area and was the location of an exploratory hole drilled as part of the site characterization effort. An instrument package was later installed to monitor the testing. The hole was drilled to $1,071 \mathrm{~m}$ $(3,513 \mathrm{ft})$ below ground surface. An "as built' map indicated that a pit was constructed immediately east of the location (Holmes \& Narver, 1969). The well was plugged and abandoned in 1971. The primary concern is the presence of metals and organic compounds used in the drilling mud.

\subsubsection{Source Area 5 - Injection Well Area}

Well HT-2, located in Source Area 5 Injection Well Area, was used for the injection of radioactively contaminated water (Figure 2-7). Between March and July of 1965, prior to injection of the waste. $7.6 \mathrm{~m}^{3}$ (2,000 gal) of 15-percent hydrochloric acid were injected to Increase the effective porosity and permeability of the Cook Mountain Limestone. Following the acid treatment, $128 \mathrm{~m}^{3}$ (33,900 gal) of radioactively contaminated water were injected into the well. The waste had a total activity of 38 curies of beta-gamma emitrers and 3,253 curres of tritium. Following injection of the waste, an additional $340 \mathrm{~m}^{2}$ (90.000 gal) of fresh water were injected.

A holding tank, referred to as the brine disposal tank, was used at the HT-2 injection well site. The tank was a former drilling mud tank that was used for the storage of contaminated liquids during the HT-2 disposal operations. During site decommissioning from 1970 to 1972. the tank was moved to Station 1-A to hold water removed from the mud pit. This water was then injected into the shot cavity by gravity flow (Brady and Milton, 1972). The tank was then filled with scrap metal from the cable yard along with miscellaneous contaminated scrap. and was shipped to the NTS for disposal.

Information concerning the integrity of the brine disposal tank during its operation period is not available. However. it is reported that one truck containing decontamination rinsate was left running, resulting in a spill at the site. The spill area was cleaned up immediately. 
Wells HT-2m, HT-2A, and HT-2C, and the device assembly area and HE storage area are not included in this RI because there is no evidence of any contamination.

\subsubsection{Source Area 6 - Helicopter Pad and Storage Area}

The Helicopter Pad and Storage Area was a 1.5-hectare (3.7-acre) site located about 1,220 m $(4,000 \mathrm{ft})$ east of the leased area boundary on the south side of the northeast access road (Figure 2-8). The type of storage done at the site is unknown. It is believed that no maintenance or refueling activities were conducted at this site (Personal Communication, Mr. D. Duncan, DOE-NV, August 15, 1990); however, if such activities occurred, solvents, degreasing agents, fuels, and antifreezes may have been stored and/or used at this site. These materials, if present and not properly stored and handled, could have resulted in contamination.

\subsubsection{Other Engineered Structures}

Following decommissioning, few of the structures on the site remained. Today, the primary engineered structures on the site include drainage improvements and preexisting gas and oil exploration holes. Poured concrete foundations also remain at Station E-7, near the shafts in Area 4 , around some active monitoring wells, and around plugged wells.

\subsection{Physical Setting}

In this section. the physical characteristics of the SS are summarized. A more detailed description and discussion of the site's physical setting is presented original Work Plan. Site characteristics such as geology, water resources, climate, and existing use provided the basis for the conceptual model of the site. This conceptual site model provides the framework for understanding the occurrence and movement of contamination at the site, a prerequisite for evaluating the risk associated with identified contaminants of concern.

Southern Mississippi generally exhibits moderate relief ( 0 to $152 \mathrm{~m}$ [0 to $500 \mathrm{ft}]$ ) with typically low hills drained by broad stream drainages. The dense vegetative cover over most of the area reflects the moderate climate and high annual precipitation. The SS is situated in the low hills of the piney woods area of the Gulf Coast region. This area is characterized by narrow, flat-topped ridges and intervening valleys that trend predominantly in a south-southeast direction toward the Gulf of Mexico. The maximum relief at the site. is about $30 \mathrm{~m}(100 \mathrm{ft})$ with elevations ranging from about 76 to $107 \mathrm{~m}$ ( 250 to $350 \mathrm{ft}$ ) above mean sea level. 


\subsection{Geology}

The SS is situated in a major regional geologic province referred to as the Mississippi Embayment. The Mississippi Embayment is a 259,000 square kilometer $\left(\mathrm{km}^{2}\right)(100,000$ square mile $\left.\left[\mathrm{mi}^{2}\right]\right)$ wedge-shaped region that extends from southern Illinois and southwestern Missouri to Texas. Louisiana, Mississippi, and Alabama and includes parts of nine states.

Salt domes, such as Tatum Dome, occur in the southern third of the Mississippi Embayment. The Mississippi Salt Dome Basin, as defined by Spiers and GandI (1980), and shown in Figure 2-13 of the original Work Plan, contains more than 50 piercement-type salt domes. Tatum Salt Dome is somewhat unique in that it is a simple, unfaulted, cylindrical salt stock whereas the majority of the salt domes in the salt basin have some degree of faulting. The basin is bounded by a number of regional structural features, most notably the Pickens Gilbertown Fault System on the north, the Monroe-Sharkey Uplift on the east, and the South Mississippi Uplift and Wiggins Anticline on the south.

The geologic strata that have been deposited in the Mississippi Salt Dome Basin represent unconsolidated or poorly consolidated sediments comprising interbedded, discontinuous sandstone and shale with minor marls, and limestones. In the southern portion of the basin, where Tatum Dome is located, the predominant lithology is shale.

A general stratigraphic column for the salt dome basin is shown in Table 2-3 of the original Work Plan. According to Spiers and Gandl (1980), the deepest unit penetrated by drilling is the Louann Salt, a thick Jurassic age halite deposit. This deposit is overlain by upper Jurassic Sandsiones followed by a thick sequence of Cretaceous age deposits consisting primarily of sandstones. limestones, and shale. The Cretaceous deposits are overlain by Tertiary deltaic deposits and alluvium of Quaternary or Recent age.

Prior to 1960, most of the published information on the hydrogeology of southern Mississippi was prepared under the auspices of the Mississippi Bureau of Geology at the county or subcounty level. The U.S. Geological Survey (USGS) conducted numerous water resource investigations in the area beginning in the early 1960s. Cushing et al. (1964) discuss the general characteristics of the embayment and Eargle (1968) provides a detailed description of the stratigraphy and structure in the vicinity of the Tatum Salt Dome. Payne (1968, 1970, 1972, and 1975) presented extensive material on the hydrology of the Claiborne Group, which includes Sparta Sand member, Cockfield Formarion. Cane River Formation, and the Meridian Sand member. These reports are complemented by later studies by Newcome (1976) for the Sparta 
Aquifer, and by Spiers (1977a, 1977b) for the Winona-Tallahatta and Cockfield aquifers. The Miocene and younger aquifers were addressed by Newcome (1975), Boswell (1979), and Gandl (1979). A summary appraisal of the region's water resources is provided by Cederstrom et al., (1979).

Aquifer testing and water level data have been summarized by Newcome (1971). More recently, Wasson (1980a, 1980b, 1980c, 1980d, 1981) developed water level maps for the Cockfield, Sparta, Winona-Tallahatta, Meridian-upper Wilcox, and lower Wilcox Aquifers.

Extensive monitoring of the SS has been conducted by the DOE (formerly the AEC), the EPA, and the state of Mississippi. Prior to the commencement of testing activities at the SS, the AEC drilled exploratory boreholes in and around the salt dome. A total of 19 borings, ranging in depth from 272 to $1,373 \mathrm{~m}$ ( 893 to $4,504 \mathrm{ft}$ ) below land surface. were drilled. Table B-1 in Attachment 5 of the original Work Plan summarizes the pertinent information from each boring.

Monitoring the environment at the SS has been a continuous effort starting before execution of the Salmon Event in 1964 to the present time. Prior to the Salmon Event, water samples were collected and analyzed by the Public Health Service. In addition. to predict the redistribution of radioactive nuclides by groundwater transport. a three-year exploration. drilling, and analysis program was undertaken by the U.S. Bureau of Mines and the USGS. Approximately 30 holes were drilled on Tatum Dome for this program. Four of these wells have been incorporated into the LTHMP. The other 26 wells have been plugged. Details of the plugging operations are given in Medley (1972).

Post Salmon Event soils and groundwater sampling were performed during November and December 1964, each month of 1965 , and January of 1966. All known aquifers were sampled as well as domestic supply wells selected out to $8 \mathrm{~km}(5 \mathrm{mi})$ from SGZ, Half Moon Creek, Grantham Creek, and lower Little Creek. Samples of soil and vegetation were collected for analysis in July 1965.

The monitoring of water, both onsite and offsite, in the vicinity of the SS has been extensive. A summary of the past and present monitoring wells is presented in Table B-2 and Table B-3 in Attachment 5 of the original Work Plan.

In 1972, the LTHMP was implemented. The program was designed to (1) assure the public safety: (2) inform the public, the news media, and the scientific community; and (3) document 
compliance with existing federal, state, and local antipollution requirements (Fenske and Humphrey, 1980). The LTHMP collects samples from potable aquifers, individual wells, public water supplies, and surface water.

In addition to the LTHMP, a drilling program was implemented in 1979 to search for radionuclides in aquifers overlying the dome and to determine the rates and directions of flow of any aquifer found to be contaminated. These monitoring holes were sited in a circular array around the SGZ monument. The specifics about the aquifer testing are contained in the original Work Plan. The results of the aquifer tests are presented in Table 2-4 and the rates and direction of groundwater movement are presented in Table 2-5 of the original Work Plan.

\section{- 2.3.1 Hydrogeology}

The regional hydrogeology in southern Mississippi has been exterisively studied. In this section, the general regional and local hydrogeologic regimes at the site are summarized. A more complete discussion is contained in the original Work Plan, which provides a conceptual model of the Tatum Dome hydrogeologic regime and represents the DOE's present level of understanding of this site. The SS is located in the Atlantic and Gulf Coastal Plain GroundWater Region, as defined by Heath (1984). This region is characterized by a series of unconsolidated deposits of gravel, sand, silt, and clay that are underlain by thick sequences of consolidated rock. Figure 2-17 of the original Work Plan shows the general geologic setting of the region. The site is within the Mississippi Embayment flow system. a major part of this groundwater region.

Groundwater occurs at shallow depths below the land surface throughout the region surrounding the SS. On a regional scale, groundwater flow is primarily in a southerly or southeasterly direction away from recharge areas situated in central and northern Mississippi. Regional groundwater discharge areas are along the axis of the Mississippi Embayment and the Gulf Coast.

As noted by Spiers and Gandl (1980), the presence of salt domes in the Mississippi Salt Dome Basin does not significantly affect regional groundwater flow in the basin, although local flow in the immediate vicinity of the dome may be altered. The hydrogeologic conditions on a regional scale are well defined and relatively straightforward. The conditions on the local, near-dome scale can be very complex as a result of the effect of the dome formation on the surrounding aquifers. 


\subsubsection{Local Hydrogeologic Regime}

An understanding of the local hydrogeologic regime at the SS is an important element in the development of a site conceptual model. Preliminary estimates are that groundwater is an important mechanism by which contamination at the site might migrate to potential receptors. In this section. the general hydrology of the aquifers under the site and their significance with respect to contaminant transport are summarized. Additional details regarding the local and regional hydrology are furnished in the original work plan.

In the following sections, the major characteristics of the local hydrogeologic regime are presented.

\subsection{Uppermost Aquifers}

There are three near-surface aquifers at the site: the Upper Aquifer, the Citronelle Aquifer, and Half Moon Creek Alluvial Aquifer. The Upper Aquifer consists of gravelly and sandy lenses in the Citronelle Formation, a Pliocene-Pleistocene age unit, and more recent terrace and alluvial deposits that occur along major drainages (PSD, 1975; Fenske and Humphrey, 1980). The Citronelle Aquifer occurs at the contact of the Pascagoula of Hattiesburg and Citronelle contact. In the vicinity of the SS, this aquifer is primarily a red-orange silty sand. The Citronelle Formation is usually about $24 \mathrm{~m}$ ( $80 \mathrm{ft}$ ) in maximum thickness, and crops out on the slopes and tops of hills at the SS. The Half Moon Creek Alluvial Aquifer (HMCAA) consists of alluvial deposits with more coarse-grained gravels and sands predominating. The HMCAA is limited to the reaches of the major drainages.

In Lamar County, the upper aquifers are a minor source of water for domestic wells and stock wells and accounts for about 2 percent of the groundwater pumped in the county (TETC, 1986). Recharge to this aquifer is derived directly from precipitation over the aquifer. Flow is from the

- highland areas toward local discharge areas represented by springs and streams. The discharge to streams sustains the large base flow common to streams in the area (Fenske and Humphrey, 1980). Downward leakage of water from the upper aquifers into the underlying Miocene aquifers also occurs (Spiers and Gandl, 1980).

In the vicinity of SGZ, the HMCAA extends from the top of the water table (generally less than $3 \mathrm{~m}$ [10 ft] below land surface) to a depth of about $46 \mathrm{~m}$ (150 ft) below land surface. A published map of the elevation of the top of the water table for the unconfined aquifer does not exist and no maps of the water tables have been prepared because there is insufficient data: however, it is believed that flow in these aquifers generally coincides with the topographic 
expression, i.e., from recharge areas in the upland areas toward the streams that drain the area (Half Moon and Grantham Creeks) (Fenske and Humphrey, 1980).

Because groundwater in the HMCAA in the vicinity of SGZ has been contaminated with tritium and trace levels of organic constituents have been detected. the understanding of groundwater flow paths and directions in this aquifer is an important consideration in evaluating the extent and magnitude of contamination at the facility. This is also crucial for the baseline risk assessment to identify the potential impact on human and sensitive ecological receptors.

The flow direction is expected to be locally quite variable, reflecting the location of the upland areas where recharge occurs and the drainage where the aquifer discharges groundwater to the surface water regime. For example, in the vicinity of Source Area 1 (SGZ) flow is probably to the east, northeast, and southeast toward Half Moon Creek, while flow under Source Area 2 (Northern Disposal Area) is to the southwest, which is toward Half Moon Creek.

The ability of the upper aquifers to transmit groundwater is also an important consideration in evaluating contamination at the SS. No data on the permeability or transmissivity of the upper aquifers are known to exist. The collection of data on the hydraulic properties of the upper aquifers will be required as part of the RI.

\subsection{Miocene Aquifer System (Local Aquifer and Aquifers 1, 2a, 2b, 3a, and Caprock Aquifer)}

The Miocene Aquifer System in Mississippi is a large important aquifer system that crops out over the southern third of the state except where overlain by the Citronelle Formation iSpiers and Gandl. 1980). This system comprises numerous interbedded sand and clay units of the Pascagoula and Hattiesburg Formations and the Catahoula Sandstone. The Miocene Aquifer System is the most important groundwater supply source in Lamar County. About 98 percent of all groundwater pumped in the county is from this aquifer system (TETC, 1986).

Based upon data collected during the extensive drilling activities at the SS, this aquifer system may be differentiated into 8 discrete hydrostratigraphic zones, each representing a discrete aquifer. Summary descriptions of each of these zones are provided in the following sections.

\section{Local Aquifer}

The Local Aquifer comprises the uppermost water bearing zone of the Pascagoula and Hattiesburg Formation (undifferentiated), a Miocene age unit of greenish-gray colored sand, silt, 
and silty clay (PSD, 1975; Spiers and Gandl, 1980; Fenske and Humphrey, 1980). Recharge to this aquifer is derived from precipitation over the area with discharge to the major streams that drain the area. The Local Aquifer is an important water supply source in Lamar County for domestic and stock wells.

The Local Aquifer occurs at depths of $46 \mathrm{~m}$ (150 ft) below land surface in the vicinity of SGZ (Fenske and Humphrey, 1980) and is about $30 \mathrm{~m}$ (100 ft) in thickness. On a regional basis, flow in this aquifer is believed to be generally to the southwest (TETC, 1986). Locally, the effects of water well pumping can alter the natural flow direction and, because of this pumping, the flow under the SS may be more easterly (Fenske and Humphrey, 1980).

The transmissivity of the Local Aquifer generally ranges from about (1,000 gallons per day per foot [gpd/ft]) to about $3.800 \mathrm{gpd} / \mathrm{ft}$ (Fenske and Humphrey, 1980; PSD, 1975). These transmissivity values are for wells completed at the SS.

\section{Aquifers 1, $2 a$, and $2 b$}

Aquifers $1,2 \mathrm{a}$, and $2 \mathrm{~b}$ comprise individual water bearing zones of the undifferentiated deposits of the Pascagoula and Hattiesburg Formations (Chapman and Hokett, 1990; Fenske and Humphrey, 1980). These units are believed to be continuous across the SS and are separated by discontinuous and less permeable clay beds that serve as aquitards (PSD, 1975). Many water supply wells in Lamar County draw their groundwater from one or more of these aquifers.

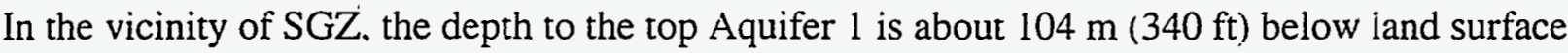
and the aquifer is about $18 \mathrm{~m}$ ( $60 \mathrm{ft}$ ) thick. Aquifer $2 \mathrm{a}$ is about $24 \mathrm{~m}$ ( $80 \mathrm{ft}$ ) thick and begins at a depth of about $136 \mathrm{~m}$ (445 ft); the top Aquifer $2 \mathrm{~b}$, about $27 \mathrm{~m}$ (90 ft) in total thickness, is about $183 \mathrm{~m}(600 \mathrm{ft})$ below land surface. Collectively, these aquifers are an important source of water for municipal water supply well fields.

The direction of flow through these aquifers is variable reflecting both the regional flow system and local perturbations of that flow induced by well-pumping. Regional flow through this aquifer is to the southeast.' south, and southwest (TETC, 1986). Locally, however, the direction of flow may be quite different than the regional flow. Because of the effects of local pumping, the flow through the Miocene Aquifer System in the vicinity of the SS may be easterly (Fenske and Humphrey, 1980). 
Wells completed in Aquifers 1, 2a, and $2 \mathrm{~b}$ have exhibited transmissivities ranging from 1,000 gpd/ft to over 200,000 gpd/ft for wells completed at the SS (Fenske and Humphrey, 1980). Elsewhere in Lamar County, the transmissivity has been found to range from $4,500 \mathrm{gpd} / \mathrm{ft}$ to $166,000 \mathrm{gpd} / \mathrm{ft}$ (TETC, 1986). This relatively high range in transmissivity across three orders of magnitude may reflect lithologic and thickness variations, the depths of the wells tested, and/or the methods used in calculating these estimates.

\section{Aquifer $3 a$}

Aquifer $3 \mathrm{a}$ is the upper part of the Catahoula Sandstone and occurs at a depth of about $236 \mathrm{~m}$ $(775 \mathrm{ft}$ ) under SGZ where a total thickness of about $30 \mathrm{~m}$ (100 ft) is present (Fenske and

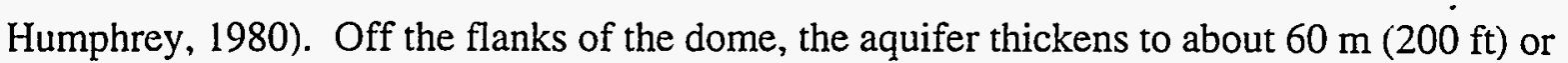
more (PSD, 1975). Aquifer 3a is the deepest frēshwater aquifer in southern Lamar County and is the deepest water supply aquifer used in the area.

On a regional basis, flow in this aquifer is generally to the southeast, south, or southwest (TETC, 1986). At the SS the direction of flow in this aquifer has been reported to be to the eastnortheast (Fenske and Humphrey. 1980). This local perturbation maybe related to the effects of local pumping.

The transmissivity of Aquifer 3a has been found to range from 1,800 to about $24,000 \mathrm{gpd} / \mathrm{ft}$ at the SS (Fenske and Humphrey, 1980). Elsewhere in Lamar County, a range of 6,900 to 13,000 gpd/ft has been reported (TETC, 1986).

\section{Aquifer $3 b$}

Aquifer $3 \mathrm{~b}$ is the Tatum Limestone Member of the Catahoula Sandstone. This unit is not present over the Tatum Salt Dome but does occur in the subsurface on the flanks of the dome at depths in excess of $267 \mathrm{~m}(875 \mathrm{ft})$. It ranges from about $30 \mathrm{~m}$ ( $100 \mathrm{ft}$ ) in thickness near the dome to about $61 \mathrm{~m}(200 \mathrm{ft})$ in thickness about $457 \mathrm{~m}$ (1,500 ft) away from the dome (PSD, 1975). The base of freshwater in this part of Lamar County is probably near the base of this aquifer at an elevation of about $427 \mathrm{~m}(1,400 \mathrm{ft})$ below mean sea level:

No data are available on the direction of flow in Aquifer 3b. On a regional scale it is probably to the southwest (Fenske and Humphrey, 1980). No tests of the aquifer have been conducted in Lamar County, thus transmissivity values are not available. 
The Tatum Limestone Member is the shallowest aquifer that has been penetrated by the upward movement of the salt dome. As a consequence, Aquifer $3 b$ is absent in the area over the top of the dome. As of 1982, there were no water wells in Lamar County that extended beyond a depth of $297 \mathrm{~m}$ (975 ft) below land surface (Spiers and Gandl. 1980), thus, it is not considered likely that Aquifer $3 \mathrm{~b}$ is used as a water supply source.

\section{Caprock Aquifer}

The Caprock Aquifer is present only over the salt dome. It produces fresh and saline water from fractures and solution cavities in limestone and anhydrite (Fenske and Humphrey, 1980).

Although its areal extent is limited to the salt dome, it may be hydrologically connected with Aquifers 3 and 4 :

\subsection{Oligocene Aquifer System (Aquifer 4)}

The Oligocene Series (a geochronologic classification including all rocks of Oligocene age) in Mississippi includes the Paynes Hammock Sand, Chickasaway Limestone, Vicksburg Group, and Forest Hill Formation, in descending order. The Paynes Hammock Sand and Chickasawhay Limestone are not considered aquifers, and the upper unit of the Vicksburg Group, the Bucatunna Formation, is considered a confining unit (Spiers and Gandl, 1980).

- The underlying units of the Vicksburg Group, in descending order, are the Bryam, Glendon, Marianna, and Mint Spring Formations; collectively, these formations are termed the Oligocene Aquifer System. In the literature on the SS. this system is referred to as Aquifer 4.

The Oligocene Aquifer System is another large aquifer in southern Mississippi, but because of its lower production capacity, it is not as heavily developed (Spiers and Gandl. 1980): Unlike the overlying Miocene Aquifer System and Citronelle Aquifer, the Oligocene Aquifer System receives its recharge primarily over its outcrop area, a relatively narrow band extending from near Vicksburg on the west to central Wayne County on the east. Thus, water in the Oligocene System (Aquifer 4) at the SS was derived from precipitation in Clarke and Jasper Counties.

Flow in Aquifer 4 is to the south-southwest (Fenske and Humphrey, 1980; TETC, 1986). No data are available concerning the transmissivity of this aquifer.

Aquifer 4 is not a source of water in Lamar County and, as a consequence, no potential receptors are withdrawing water from the aquifer. The base of groundwater with a total dissolved solids (TDS) concentration of less than 3,000 parts per million (ppm) occurs in the upper part of this 
aquifer at an elevation of about $488 \mathrm{~m}(1,600 \mathrm{ft}$ ) below sea level (about 1,850 ft below the land surface). All groundwater within this aquifer has a TDS concentration of greater than $1,000 \mathrm{ppm}$ (Spiers and Gandl. 1980).

\subsection{Eocene Hydrostratigraphic Units (Aquifer 5)}

Underlying the Oligocene Aquifer System is a sequence of Eocene sediments that include, in descending order, the Cockfield Formation, Cook Mountain Formation, and the Sparta Sand. Because of the salinity of the groundwater in these units, they are not considered aquifers in central and southern Lamar County. In more northern counties the Cockfield Formation and Sparta Sand are important water supply aquifers, but the Cook Mountain Formation is not considered a freshwater aquifer.

Because of the saline groundwater present in Aquifer 5, it has been extensively used for the injection of wastewater streams generated by the petroleum industry. Baxterville, located about $4.8 \mathrm{~km}$ ( $3 \mathrm{mi}$ ) southwest of the $\mathrm{SS}$, has been an active center for such injection for almost 40 years (Fenske and Humphrey, 1980) and injection has also occurred at Pistol Ridge, to the southeast in Forrest County, but at a much lower rate (TETC, 1986). Because of the injection of wastes into Aquifer 5, the direction of flow is believed to have been altered. Under natural conditions, the flow through the Cook Mountain Formation is to the southeast: however, the pressure gradient induced by the injection of wastes into the aquifer has reversed this flow, and the flow in the vicinity of the SS is believed to be to the northeast (Fenske and Humphrey, 1980).

Limited data are available on the transmissivity of the Cook Mountain Formation. Only two tests have been conducted in Lamar County resulting in estimates of transmissivity ranging from 1,500 to $2,000 \mathrm{gpd} / \mathrm{ft}$.

\subsubsection{Surface Water}

The SS is situated in the Pearl River Basin. This river, with a total drainage area of about $22,700 \mathrm{~km}^{2}\left(8,760 \mathrm{mi}^{2}\right)$, flows into the Gulf of Mexico. Low-flow characteristics of streams in the basin are presented by Speer et al. (1964).

The surface water regime in the vicinity of the SS is an important consideration in evaluating the effects of past activities at the site and potential remedial efforts. Three major streams, Half Moon Creek, Hickory Hall, and Grantham Creek, drain the area. These streams receive groundwater discharge baseflow from the surficial aquifer. 
Reservoirs located on the SS may also be important hydrologic features. The two reservoirs of most concern are Beaver Pond and the Half Moon Creek Overflow Pond, which received runoff and groundwater discharge that was contaminated with tritium.

The streams and reservoirs at the site are expected to have a pronounced effect on the flow of groundwater in the HMCAA. The streams act as drains along which the upper aquifers discharge groundwater. The reservoirs represent sources where the upper aquifers are recharged, and probably represent constant head boundaries that should be taken into account in evaluating the feasibility of remedial alternatives for ground or surface water cleanup.

\subsubsection{Climate}

The climate in Lamar County is classified as semi-tropical, with warm, humid summers and generally mild winters. The mean annual precipitation ranges from 145 to $200 \mathrm{~cm}$ (57 to $79 \mathrm{in}$.) in the SS Area, with a long-term average of $150 \mathrm{~cm}$ (59 in.). The heaviest rainfalls occur in the summer and fall. Thunderstorms occur 70 to 80 days per year. Temperatures in the SS vicinity range from near freezing 0 degrees Celsius $\left({ }^{\circ} \mathrm{C}\right)\left(32\right.$ degrees Fahrenheit $\left.\left[{ }^{\circ} \mathrm{F}\right]\right)$ in December and January to $\left(35^{\circ} \mathrm{C}\left[95^{\circ} \mathrm{F}\right]\right)$ in July and August. The mean annual temperature for 1985 through 1989 was $18.6^{\circ} \mathrm{C}\left(65.5^{\circ} \mathrm{F}\right)$. The average annual evapotranspiration rate in south-central Mississippi is $94 \mathrm{~cm}$ ( 37 in.), which amounts to about 63 percent of the precipitation.

\subsubsection{Environmental Resources}

Numerous environmental resources are present in Lamar County; the forests provide recreation, aesthetic enjoyment, and a habitat for wildlife. Timber harvesting is also an important component in both environmental and economic resources of Lamar County. The many creeks and streams provide habitats for riparian. vegetation and animals. There are sixteen flora species and twenty fauna species existing in Lamar County that are state or federal candidates (listed, or proposed endangered, threatened, rare or otherwise significant species). The Mississippi Natural Heritage Program, a division of the state of Mississippi Department of Wildlife, Fisheries and Parks provided the lists of "special" flora and fauna for Lamar County, Mississippi. Each species is given a code to describe its status at the federal and state level as shown in Table 2-9 of the original Work Plan. A Threatened and Endangered species study was completed in 1992 (DOE. 1992b). The Gopher Tortoise (Gopherus polyphemus) was the only species identified as being threatened and endangered. 


\subsection{Initial Evaluation}

\subsection{Introduction}

The SS is the subject of an ongoing RJ/FS to determine the existence of contamination, its extent, and what remedial actions, if any, should be taken to mitigate effects and minimize risk to the environment. A series of activities were planned under the FACP and EEC sections of the original work plan (DOE, 1992a). These activities were designed to determine what, if any, contaminants are present, their concentrations, and their effects on the ecology at the SS.

The investigative activities completed thus far at the SS can be grouped into eight general categories and are shown in Table 3-1.

Table 3-1

Sampling and Survey Activities Compieted at the Salmon Site, Lamar County, Mississippi

\begin{tabular}{|c|c|c|}
\hline Survey/Sampling Event & Activity Dates & Report Date $^{a}$ \\
\hline $\begin{array}{l}\text { National Environmental Protection Act: } \\
\text { Threatened and Endangered Species } \\
\text { Wetlands and Floodplain }\end{array}$ & $\begin{array}{l}\text { July } 1992 \\
\text { July } 1992\end{array}$ & $\begin{array}{l}\text { October } 1992 \\
\text { October } 1992\end{array}$ \\
\hline Cultural Resources & April 1992 & July 1992 \\
\hline Surface geophysics & $\begin{array}{c}\text { November } 2 \text { to } 26,1992 \\
\text { April } 22 \text { to May } 7,1993 \\
\text { September } 1 \text { to October } 16,1993\end{array}$ & January 1995 \\
\hline $\begin{array}{l}\text { Aquatic, Terrestrial and Groundwater } \\
\text { Sampling }\end{array}$ & $\begin{array}{l}\text { February } 22 \text { to } 28,1993 \\
\text { April } 22 \text { to } 30,1993\end{array}$ & April 1994 \\
\hline $\begin{array}{l}\text { Cone Penetrometer Testing and Soil and } \\
\text { Groundwater Sampling }\end{array}$ & October 19 to November 11,1993 & October 1994 \\
\hline Trench Excavation & December 8 to 17,1993 & May 1994 \\
\hline Baselıne Ecologıcal Risk Assessment & & April 1995 \\
\hline $\begin{array}{l}\text { Tatum Salt Dome Test Site Descriptive } \\
\text { Cancer Study }\end{array}$ & & April 1995 \\
\hline
\end{tabular}

\footnotetext{
${ }^{a}$ Report Issue Date, the complete reference is given in Section 8.0. References Cited.
}

Not included as a part of the RI/FS referenced here for information only. 
The technical approach to SS field investigations is detailed in the Remedial Investzgation and Feasibility Study of the Tatum Dome Test Site, Lamar County, Mississippi (DOE. 1992). The surveys and sampling events were carried out in several phases between April 1992 and -December 1993. All surveys and sampling activities were conducted in accordance with the EEC, FCP. and procedures outlined within the RI/FS Work Plan (DOE, 1992). Samples collected during the various phases were analyzed for both radiological and nonradiological constituents of concern (COC). The analytical methodology generally followed the U.S. Environmental Protection Agency Contract Laboratory Program (CLP) guidelines.

\subsection{Known and Potential Contamination}

\subsubsection{Surface Ground Zero}

\subsubsection{AOC 1-A, Station 1-A Shot Cavity}

During nuclear testing, a number of fission by-products and other materials were released into the area immediately adjacent to the point of detonation. According to Borg et al. (1976), the by-products generated during underground nuclear testing include three sources of radionuclides: (1) original nuclear material that did not undergo a fission or thermonuclear reaction; (2) fission products, including antimony, barium. cesium. strontium. and other radionuclides: and (3) activation products. Activation products include radionuclides or elemental isotopes produced by neutron activation in the immediate vicinity of the detonation and include primarily tritium, calcium, argon, and iron. Other materials that may have been released inciude lead from shielding materials, traces of synthetic materials used in cables. and residuals from stemming materials (epoxies used to bond materiais in the emplacement boring).

The detonations at the SS were fully contained and no releases to the surface environment occurred during any of the testing. Following testing, reentry borings were drilled into the shot cavity resulting from the detonations. Analysis of data from these borings led to the conclusion that most of the radioactivity released is now contained in a solidified melt that was deposited in the bottom of the shot cavity (DOE. 1978; AEC, 1972).

\subsubsection{AOC 1-B, Beaver Pond}

The Beaver Pond is the result of the damming of the culverts that drained the marsh area under the access road that trends northeast from SGZ. Normally swampy, the area contained small pools of water and mud prior to pond formation. Tritium contamination is known to exist and fuels and drilling fluids contamination may be present. The contaminant source is believed to be 
derived from decontamination activities and storage of contaminated equipment at the E- 6 Decontamination Pad. Runoff from the E-6 pad area naturally drains into the Beaver Pond.

Sampling of HMH-16, as well as three other wells (HMH-3. HMH-4, and HMH-6) in the vicinity of the Beaver Pond, indicated the presence of tritium (Figure 3-1). The water sample collected from HMH-16 during the 2nd and 3rd quarter of 1991 had a activity of 1,020 pCi/l. However, samples collected in 1993 and 1994 were below the lowest level of detection (LLD) and $93 \mathrm{pCi} / \ell$, respectively. The other three wells were below the LLD.

The sampling of the pond water and sediments in 1993 did not indicate the presence of any chemical COC, tritium activities were less than $400 \mathrm{pCi} / \ell$, lead 212 , radium, and uranium were detected at levels consistent with the reference samples (Figure 3-2) (DOE, 1994a).

\subsubsection{AOC 1-C, Half Moon Creek Overflow Pond}

Half Moon Creek Overflow Pond is located approximately $60 \mathrm{~m}(200 \mathrm{ft})$ east-northeast of Station 1-A. The overflow pond is known to contain tritium contamination, but the concentration is below EPA drinking water standards. The contamination is the result of drainage from the Station 1-A area.

Sampling of water and sediments from the Half Moon Creek Overflow Pond in 1993 indicared that the gross alpha activity exceeded that of the reference sample for the water sample but was below the Minimum Detectable Activity (MDA) (Figure 3-2). Tritium was not detected. No orher COC were identified in the water sample. Chromium and lead were identified in the sediment sample. Radiological parameters were consistent with the reference sample DOE. 1994a).

\subsubsection{AOC 1-D, Postshot No. 1 Slush Pit and "Mouse Hole"}

The Postshot No. 1 Slush Pit was located at the extreme southern portion of the Station 1-A area, and was excavated for use as a liquid waste storage pit during the Salmon. Event postshot drilling operations. The pit was filled with drilling sludge and covered with clean soil. Subsequent erosion and flooding resulted in contamination of the South Road area and the adjacent swamp.

During decommissioning, the excavation of the slush pit and adjacent contaminated areas was hampered by shallow groundwater conditions. As a consequence, the cleanup standard was 


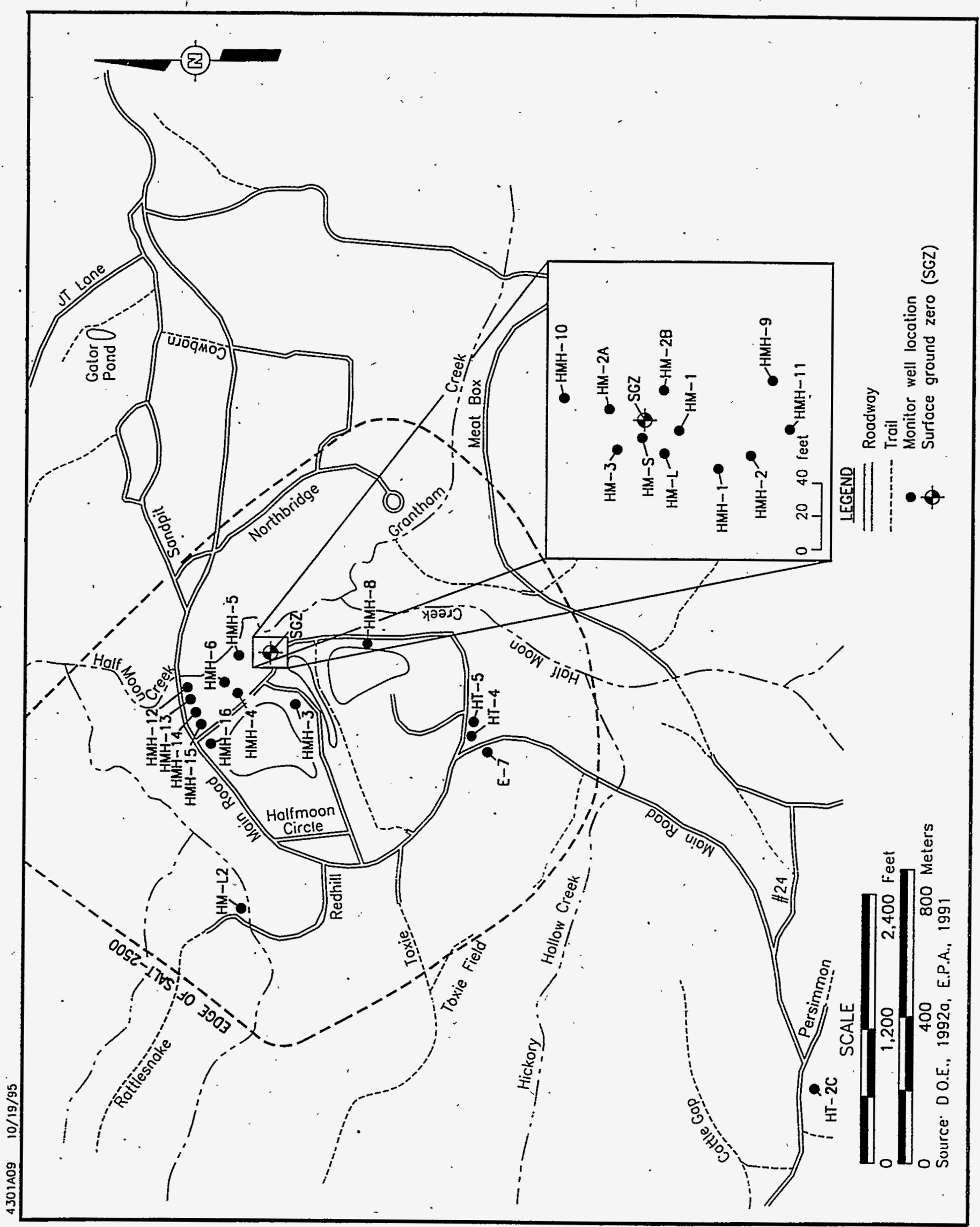

Figure 3-1

Location of Half Moon Creek Alluvial Aquifer Monitor Wells in the Vicinity of Surface Ground Zero 


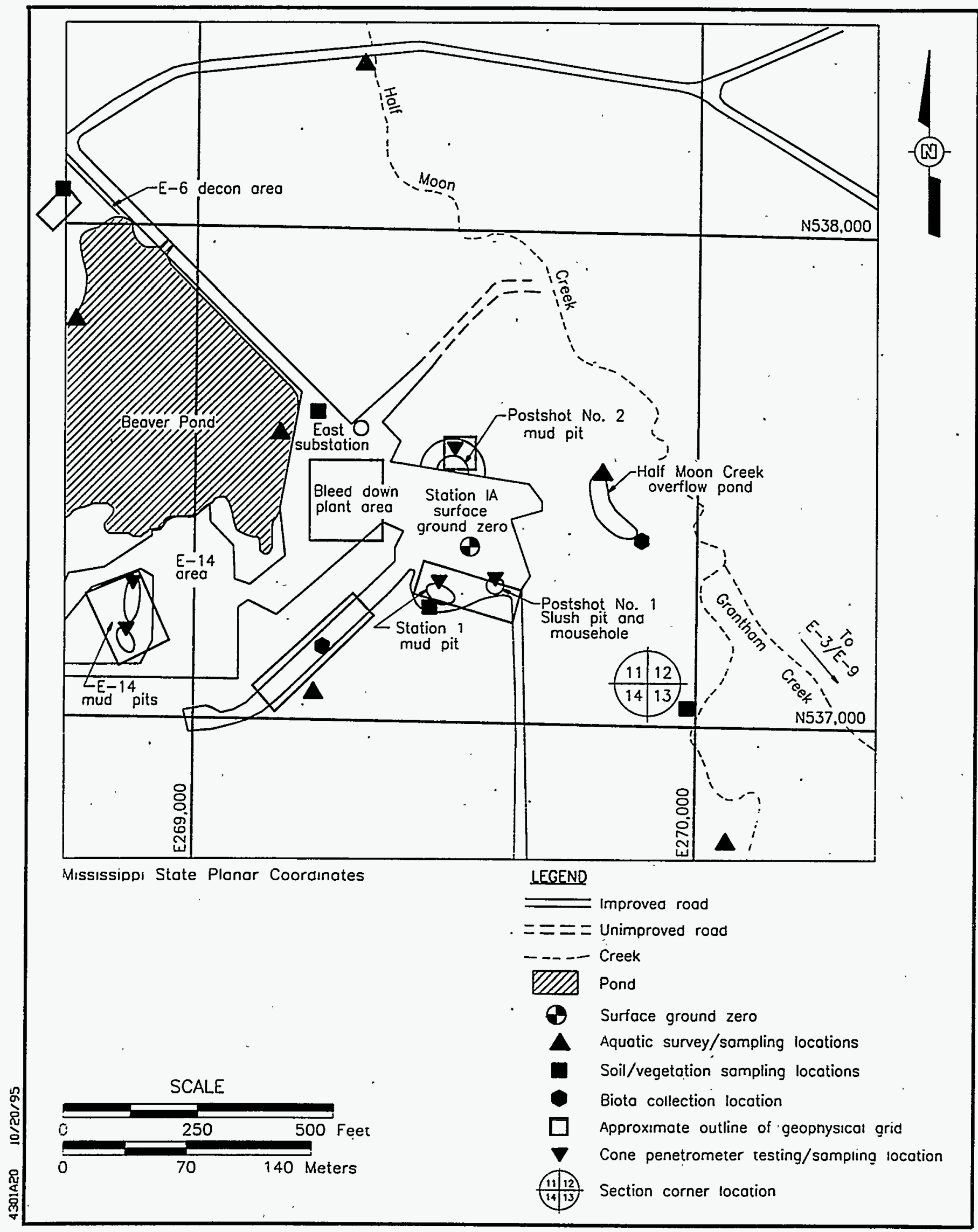

Figure 3-2

Sampling Locations in Source Area 1 
relaxed and the pit was excavated to a depth of approximately $2.4 \mathrm{~m}(8 \mathrm{ft})$, backfilled with clean dirt, and decommissioning efforts ceased at the site.

The Postshot No. 1 Mouse Hole was a recess excavated below the floor of the drilling rig deck during the first reentry boring following the Salmon Event. A mouse hole is used during drilling as a holding place for the next length of drill pipe to be added to the drill string.

Shallow subsurface (2.1- to 3-m [7- to 10-ft]) soil and water samples were collected in 1993 from this site during the Cone Penetrometer Testing (CPT) investigation (DOE, 1994c). Chromium ' and lead were identified in the soil sample at levels that exceeded the Contract Required Detection Limit (CRDL). The water sample indicated the presence of a wide variety of metals: arsenic, barium, chromium, lead mercury and nickel. Chromium and lead exceeded the Maximum Contaminant Level (MCL) permitted by the Safe Drinking Water Act (SDWA). Gross alpha and beta activity also exceeded the MCL (DOE, 1994c).

\subsubsection{AOC 1-E, Bleed-Down Plant Area}

The Bleed-Down Plant Area was located on à gravel pad adjacent to Station 1-A, and was used for the filtering and depletion of radioactive gases recovered from the shot cavity. Runoff over the area resulted in the spread of contamination from the equipment, spills, and contaminated liquid stored in the on-site mud pit. At the completion of testing, and after decontamination. the bleed-down equipment was returned to the NTS.

\subsubsection{AOC 1-F, East Substation}

The East Substation was a part of the power distribution grid at SS and was located near SGZ. There is no information available concerning this AOC. and it is not considered a likely source of contamination. Materials of a hazardous nature, particularly polychlorinated biphenyls (PCB). may have been present at the AOC at one time: however. the excavation of soils at SGZ probably resulted in the removal and disposal of any soils that may have been contaminated.

A soil sample collected from the AOC in 1993 did not indicate the presence of radionuclides, metals, or volatile organic compounds; although, Arocior 1254 (a PCB) was identified in the sample (DOE. 1994a).

\subsubsection{AOC 1-G, E-14 Pad and Associated Mud Pit}

The E-14 Pad was a $61 \mathrm{~m} \mathrm{x} 305 \mathrm{~m}(200 \mathrm{ft} \times 1.000 \mathrm{ft})$ rectangular area located northwest of the Bleed-Down Plant Area. The E-14 Mud Pits are located west of the E-14.pad. The pad was 
originally used as a storage area for the holding of contaminated drill pipe and well casing pulled from postshot drill holes. The site was bladed and gráveled.

Contaminated drill pipe was stored on the pad for several years. Deterioration of this pipe through corrosion and scaling resulted in contamination of soil in the northwest part of the pad and contamination off the pad.

Two soil and two water samples were collected from the shallow subsurface ( 5.8 to $7.6 \mathrm{~m}$ [19 to $25 \mathrm{ft}]$ ) in 1993. Carbon disulfide was detected in one water sample. Arsenic, barium, cadmium. chromium, lead, mercury, and nickel were also identified in both water and soil samples. Barium. cadmium, chromium, and lead exceeded the MCL in both water samples. Several radionuclides were identified and the gross alpha and beta activities exceeded the MCL (DOE, 1994c).

\subsubsection{AOC 1-H, E-6 Decontamination Pad}

The E-6 Decontamination Pad was used during the Salmon and Sterling Events to decontaminate equipment and for the storage of miscellaneous contaminated equipment. Approximately 75 drums of contaminated waste were stored at this site for over five years. During decommissioning, the drums were transported to the shot cavity for disposal, and the contaminated soil at the pad was excavared and disposed of in the shor cavity.

The E-6 Decontamination Pad site included the pad proper and a sump that drained contaminated rinsate from the area. Rinsates and runoff to the sump were collected periodically for disposal at the HT-2 injection well. After site operation ceased. but before decommissioning, flooding of the site and a spill from a tanker truck resulted in the contamination of soils in the adjacent swamp area.

Well HMH-16 is located on the sire. Tritium was identified in the ground water during sampling events in 1990 and 1991. This analysis appears to be a false positive because tritium has not been detected in any subsequent sampling of the well.

Soil samples were collected from the site during 1993. No COC were identified (DOE 1994a).

\subsubsection{AOC 1-I, Postshot No. 2 Mud Pit}

The Postshot No. 2 Mud Pit was a $15 \mathrm{~m} \times 15 \mathrm{~m}$ (50 ft x $50 \mathrm{ft}$ ) drilling mud pit located about $45 \mathrm{~m}$ ( $150 \mathrm{ft}$ ) north of SGZ: A site inspection conducted during August 1990 found no indication 
of the pit remaining; however. geophysical investigations conducted in 1993 were able to accurately define the pit location (DOE, 1994d).

The pit was used after testing activities for the storage of drilling fluids, and has been found to be contaminated with tritium. Other possible contaminants include volatile organics, metals, and. fuels associated with drilling operations.

Water samples collected from monitoring wells near the site ( $\mathrm{HMH}-3$ and $\mathrm{HMH}-10$ ) indicated the presence of tritium in well $\mathrm{HMH}-10$ during several quarterly sampling events between 1990 and 1993 (MS-DOH, 1990, 1991, 1992, 1993). All of the results were less that $2,700 \mathrm{pCi} / \mathrm{l}$. A soil and water sample was collected during the 1993 CPT study. The results indicated the presence of chromium and lead in both samples. The results were at or near the CRDL for the soil sample and exceeded the MCL in the water sample. Arsenic, barium mercury and nickel were also identified in the water sample. No significant activity levels of radionuclides were detected in the soil sample. The water sample had gross alpha and beta activities that exceeded the MCL and tritium levels in excess of $50.000 \mathrm{pCi} / \ell$ (DOE, 1994c).

\subsubsection{AOC 1-J, E-3/E-9 Drill Site (New AOC)}

This is a newly identified AOC. It is located east of Source Area 1, across Grantham Creek. The primary concern is the possible contamination of the shallow ground water and Grantham Creek from the mud pits used in the drilling of the E-3 and E-9 wells (Figure 3-2). No specific information is available, althoụgh, maps indicate the presence of a pit west of the drilling pad.

\subsubsection{Source Area 2 - Northern Disposal Area}

\subsubsection{AOC 2-A, Reynolds Electrical \& Engineering Co., Inc. Disposal Pits}

The REECo Disposal Pits were initially borrow pits where material for drilling mud was obtained. During decommissioning and site cleanup, the pits were used for the disposal of noncombustible materials, uncontaminated tools, unused drilling mud, and equipment. Approximately six pits were excavated that were later filled to capacity, covered with soil, and revegetated. The pits have since eroded. and a 3.6- to 4.6-m (12- to 15-ft) deep gully has exposed bricks and concrete fill.

Water flows through the pit during high rainfall months. and a natural spring is present at the head of the pit. This area has been regularly sampled for tritium. The values generally ranged 
from 1,000 to $2,000 \mathrm{pCi} / \ell$; however, in 1983 , the tritium levels increased to $12,000 \mathrm{pCi} / \ell$. The levels returned to the previous range by 1984 and have not increased since that one occurrence.

In an effort to identify the source of the tritium, a series of subsurface soil samples were collected from above the site of the headward erosion. Analytical results indicated below minimum detectable activities for tritium although chromium and lead were identified (DOE, 1994b).

A series of samples were collected during the CPT investigation from within the confines of the. REECo pits area (DOE, 1994c) (Figure 3-3). The results of this sampling indicated the presence of chromium, lead, and barium in most of the soil samples. A full suite of water samples was only available at one location and indicated the presence of chromium, barium mercury, lead and nickel. Chromium, lead, barium, and nickel exceeded the MCL.

A geophysical survey was conducted over this area in 1993 (DOE, 1994d), which identified numerous anomalies. In late 1993, trenches were dug in an effort to determine the source of these anomalies (DOE, 1994b). The results of the trenching produced scrap iron, cable, and pipe. Analytical samples indicated the presence of diesel. chromium, and various volatile and semivolatile organic compounds. Radiological analysis railed to indicate, the presence of any radionuclides. Tritium analyses were not performed on the soil samples.

\subsubsection{AOC 2-B, Debris Burial Pits}

The Debris Burial Pits were identified from maps of the SS. No other information is available regarding materials disposed of there. and the site is considered a potential source of contamination.

A subsurface soil sample was collected from a depth of 2.3 to $2.7 \mathrm{~m}$ ( 7.5 to $9.0 \mathrm{ft}$ ) in 1993 . There were no organic compounds detected but lead was detected. Both gamma spectroscopy and gross alpha/beta analysis were above the reference sample values (DOE, 1994c).

The trenching operations indicated that cable and miscellaneous debris were buried and/or burned at the site. Sampling from one trench indicated the presence of dibenzofurans along with a wide variety of metal compounds (DOE, 1994b). 


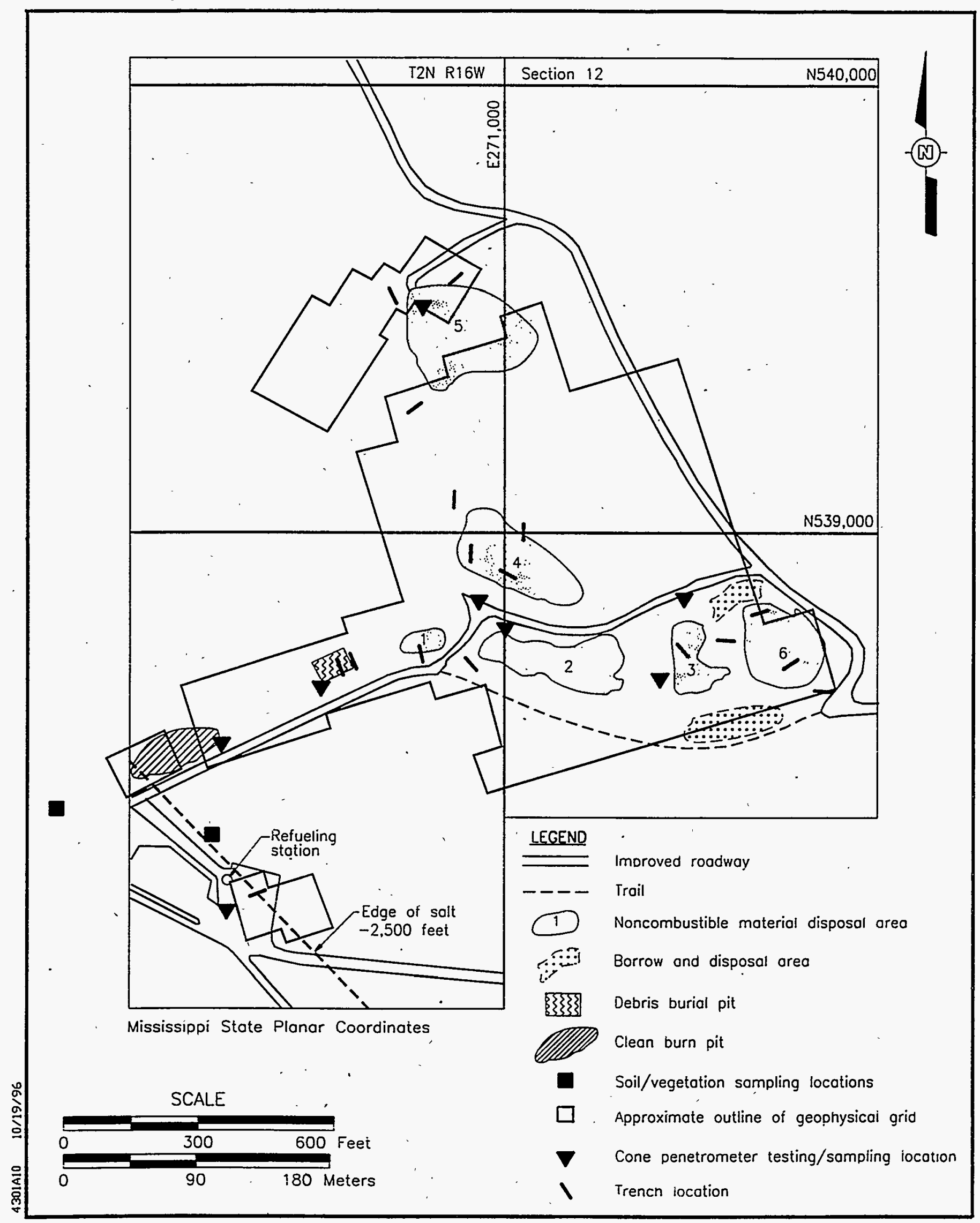

Figure 3-3

Sampling Locations in Source Area 2 


\subsubsection{AOC 2-C, Clean Burn Pits}

The Clean Burn Pits probably were used for the disposal of used motor oils and solvents. This site was identified from a map of the SS, and is considered a possible source of contaminations.

The geophysical survey did not reveal any buried ferromagnetic materials nor was the areal or vertical extent of the pit apparent from the geophysical survey (DOE, 1994d). Soil and water samples collected in conjunction with the CPT, indicated the presence of toluene in the soil sample and diethyphthlate and metals in the water sample. Gross alpha and beta activities exceeded the reference sample values for the soil sample and the MCL for the water sample (DOE, 1994c).

\subsubsection{AOC 2-D, Fueling Station (Gas Pump)}

The fueling station was most likely used to dispense gasoline or diesel fuel, and had an underground storage tank. The site is considered a possible source of hydrocarbon and lead contamination from leaded gasoline.

The results of the geophysical inyestigation indicated the presence of a large magnetic anomaly thought to be indicative of an underground storage tank (DOE, 1994d). Trenching actıvities confirmed the presence of the tank. The tank had apparently been closed in place by cutting a section of the tank away and filling it with gravel and cement. Soil samples were collected adjacent to and beneath the tank. None of the analytical results exceeded the CRDL for any of the organic COC. Arsenic, chromium. and lead concentrations exceeded the CRDL (DOE. 1994b).

\subsubsection{Source Area 3 - Southern Storage Area}

\subsubsection{AOC 3-A, Mud Storage Pits/South Barrow Pit}

The Mud Storage Pits were used as a dumping ground for drilling solutions. Possible contaminants on the site include metals, organics, and tritium.

Surface geophysical surveys conducted in late 1992 and $1993^{\circ}$ delineated the extent of the mud pıts (Figure 3-4). Magnetic anomalies were identified within the pits and excavarions have been planned but not completed (DOE. 1994d). Subsurface soil and water samples collected in 1993. indicared the presence of toluene (one water sample), endosulfan sulfate (one water sample), and arsenic, barium, chromium, lead, and nickel were also detected. Barium, chromium, and lead 
exceeded the MCL in both water samples collected from this site. Several radionuclides were detected at activity levels comparable with the reference sample (1994c).

\subsubsection{AOC 3-B, Big Chief Drilling Storage Area}

The Big Chief Drilling Storage Area was used to store drilling equipment and supplies. Possible contaminants at this storage area are metals and organics. Results of the geophysical investigations did not indicate any anomalies (DOE, 1994d). Soil samples collected from the site in 1993 had no detections of any organic COC and only trace amounts of various metal compounds. The gross alpha activity exceeded the reference sample by a factor of approximately 2.5 (DOE, 1994a).

\subsubsection{AOC 3-C, E-2 and E-7}

Sites E-2 and E-7 are exploratory holes that were drilled to predict the redistribution of radionuclides by groundwater transport. The possible contaminants at the E-2 and E-7 sites are organic compounds, tritium, and metals from drilling fluids.

Minor concentrations of pentachlorophenol were found in the groundwater from Hole E-7 during the 1993 sampling (DOE, 1994a). Because there is not a pump in the well. the well was not purged prior to sampling, so the source of the contamination is not known. Soil samples collected in 1993 did not reveal the presence of any chemical COC. Alpha activities were approximately 2.5 times the activity levels for the reference sample. Two species of radium were also detected at levels slightly above those for the reference sample (DOE, 1994a). Soil sampies collected durng the CPT testing in 1993 indicated the presence of arsenic, chromium, and lead. Low activities of several radionuclides were also noted (DOE. 1994c). Post construction engineering maps of the site (Holmes and Narver. 1969) indicate that an area approximately $15 \mathrm{~m}$ $x 76 \mathrm{~m}$ ( $50 \mathrm{ft} \times 250 \mathrm{ft}$ ) was fenced at one time. Whether or not this was the site of mud pits associated with the drilling of the E-2/E-7 well is unknown. If this was the site of the mud pits, then contamination by metals and diesel fuel is likely and may be the source of the contaminants found in the CPT soil samples (DOE. 1994c).

\subsubsection{AOC 3-D, Government Storage Area 1 (Drill Storage Yard)}

The Drill Storage Yard was a bladed and graveled area used for the storage of miscellaneous equipment. some of which is known to have been contaminated with tritium. The soil in the northeastern part of the site was found to be contaminated. and from 1965 to 1966 was fenced, and marked. Soil contaminarion was also found along the southern part of the storage yard. 


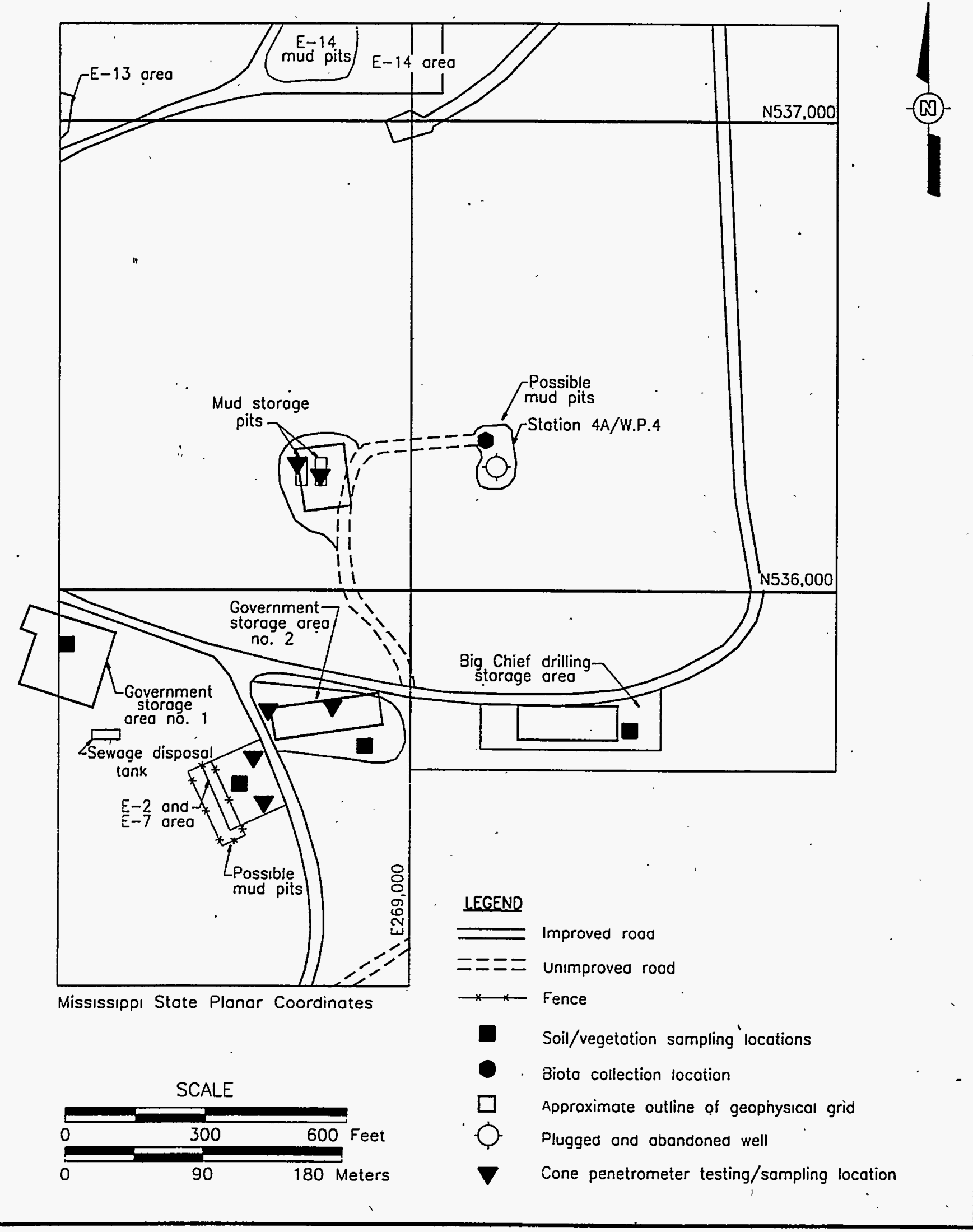

Figure 3-4

Sampling Locations in Source Area 3 
The geophysical survey produced 1 unexplained anomaly. A test pit has been recommended but not constructed (DOE, 1994d). Soil samples collected in 1993 indicated the presence of pesticides but no other COC (DOE, 1994a).

\subsubsection{AOC 3-E, Government Storage Area 2}

The Government Storage Area 2 was identified from maps. No further information is available at this time.

Geophysical investigations conducted during 1993 did not indicate any unexplained anomalies and no test trenches were recommended (DOE, 1994d). A soil sample was collected from the AOC during the 1993 sampling event. No COC were identified. Samples collected from the subsurface during the CPT investigation indicated the presence of arsenic, barium, chromium and lead at levels that exceeded the CRDL.

\subsubsection{AOC 3-F, Sewage Disposal Tank (New AOC)}

This is a newly identified AOC. It is located east of the southeastern comer of Government Storage area 2. This site was identified from historical records, but no information is available as to the types of waste disposed of at this site or whether the system was removed when the site was decommissioned (Holmes and Narver, 1969).

\subsubsection{AOC 3-G, WP 4/Station 4 Drilling Site (New AOC)}

This is a newly identified AOC. It is the site of a pair of drill holes that were apparently part of a seismic "check-shot" conducted to test the calibration of equipment. The size of the site is estımated at $30 \mathrm{~m} \times 30 \mathrm{~m}$ ( $100 \mathrm{ft} \times 100 \mathrm{ft}$ ). Both wells penetrated the salt dome (Medley. 1972). Their period of operation is uncertain. Suspected contaminants include diesel fuel. hydraulic fluid and metals associated with drilling fluid.

\subsubsection{Source Area 4 - Western Disposal Area}

\subsubsection{AOC 4-A, Reserve Mud Pit(s)}

The Reserve Mud Pit was located approximately $610 \mathrm{~m}(2,000 \mathrm{ft})$ west of SGZ. Post construction diagrams indicate that there were two pirs: one is estimated to have been as large as $23 \mathrm{~m} \mathrm{x} 91 \mathrm{~m}$ ( $300 \mathrm{ft} \times 75 \mathrm{ft}$ ) and the second. $30 \mathrm{~m} \mathrm{x} 30 \mathrm{~m}$ ( $100 \mathrm{ft} \times 100 \mathrm{ft}$ ) (Figure 3-5) (Holmes \& Narver, 1969). These pits were used for the mixing "clean" drilling fluids (no radioactive contaminants). Contaminated returns from the borehole were routed to the Postshot No. 1 Mud Pit at SGZ. Although there is no reason to suspect that the reserve mud pit 
is a source of radioactive contaminants. the AOC may contain residual drilling mud. which may have been contaminared with chromium. vanadium, or other metals. Based on the results of the trenching operations in the Northern Disposal area (Source Area 2), it is.likely that the drilling mud also contained diesel fuel (DOE, 1994b). It is unknown to what degree these pits were cleaned out during or prior to decommissioning of the AOC.

\subsubsection{AOC 4-B, Debris Burial Pit}

This AOC was identified from a map of the SS. No iniormation is available regarding materials disposed of at the site; however, it is considered a potential source of contamination.

Geophysical investigations did not identify any buried debris or the presence of significant areas of excavated material (DOE, 1994d). One small magnetic anomaly was noted west of the Vent Hole. No test excavation was proposed for this site. Sampling of the surface soils, vegetation, and shallow groundwater and soil (via CPT) identified several metal compounds (DOE. 1994a and c). Arsenic, barium, chromium, mercury, nickel, and lead were detected in both water and soil samples. Chromium and lead exceeded the MCL in both water samples. Based on the information collected from trenching activities in Source Area 2, it is presumed that these are a result of drilling mud spills during construction of the shafts. Several radionuclides were detected at low activity levels and gross alpha and beta activities exceeded the MDA.

\subsubsection{AOC 4-C, West Substation}

The West Substation was located about $457 \mathrm{~m}$ (1,500 ft) west of SGZ. There is no information available concerning this AOC. Materials of a hazardous nature, particularly PCBs. may have been present at the $\mathrm{AOC}$ at one time.

Soil samples collected during 1993 indicared the presence of the pesticide dieldrin and copper in excess of the CRDL at the site of the west substation. One of the CPT samples collected at AOC 4-B, adjacent to the west substation as discussed above. had chromium and lead concentrations that exceeded the MCL (DOE, 1994c).

\subsection{AOC 4-D, CH Fuel Storage Area}

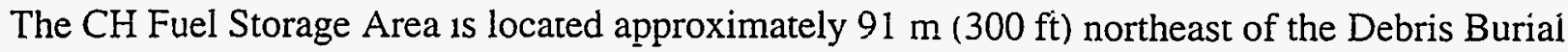
Pit. Fuels and lubricants were stored in the area, with possible spills and leakage occurring. 


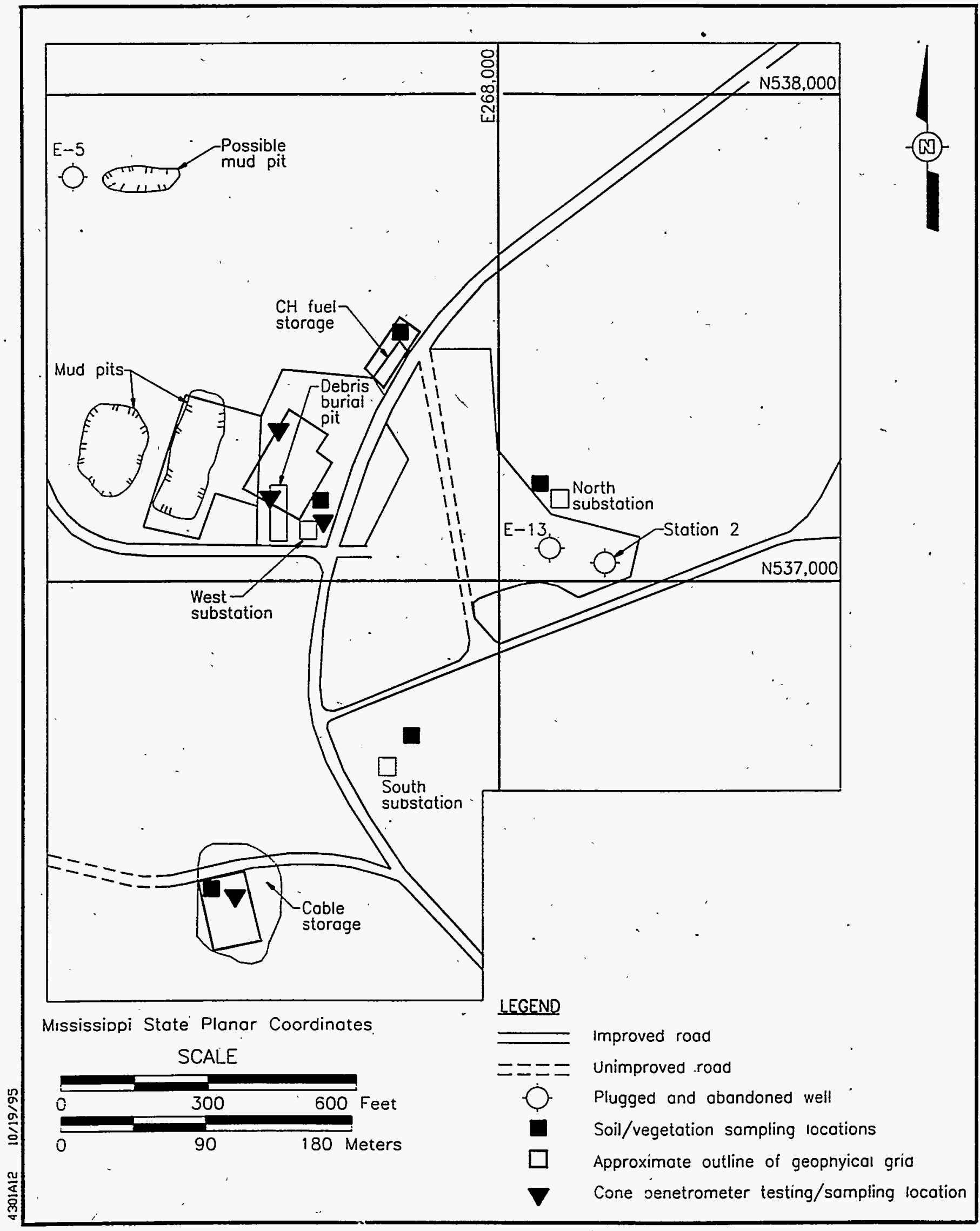

Figure 3-5

Sampling Locations in Source Area 4 
Soil samples collected in 1993 did not identify any contammation above the CRDL (DOE, 1994a). No anomalies were identified by the geophysical investigation (DOE, 1994d).

\subsection{AOC 4-E, Cable Storage Area}

This AOC was used for the storage of cables used in the seismic network to monitor the tests at the site. Copper and other types of metal cables were burned to remove the insulation from the cables. It is not known whether this was done as part of the cleanup or later by parties unrelated to the AEC. It was considered a possible source of metal contamination. Soil samples collected in 1993 did not reveal the presence of any chemical constituents. Several radionuclides were identified at levels only slightly exceeding those of the reference sample (DOE, 1994a). The samples collected during the CPT program indicated that lead exceeded the CRDL. Gross alpha and beta activities exceeded those of the reference sample and three radionuclides exceeded the reference sample values by small amounts (DOE, 1994c).

\subsection{AOC 4-F, South Substation .}

The Southwest Substation was located about $518 \mathrm{~m}(1.700 \mathrm{ft})$ southwest of SGZ. There is no information available concerning this AOC. but it is not considered a likely source of contamination. Materials of a hazardous nature, partıcularly PCBs. may have been present at the site at one time. Surface soil samples taken in 1993 did not indicate the presence of any constituent of concern (COC) (DOE, 1994a).

\subsection{AOC 4-G, North Substation}

The North Substation site was located $360 \mathrm{~m}(1,200 \mathrm{ft})$ west of SGZ. There is no information available concerning this AOL. Material of a hazardous nature. particularly PCBs. may have been present at this $A O C$ at one time. Surface soil samples taken in 1993 did not indicate the presence of any COC (DOE. 1994a).

\subsection{AOC 4-H, E-5 Mud Pits (New AOC)}

Well E-5 was drilled at a location northwest of the shaft/vent complex as an exploratory hole for the evaluation of the Tatum Salt Dome as a possible location for Project Dribble. The well reached a total depth of $1.071 \mathrm{~m}(3.513 \mathrm{ft}$ ), was apparently converted for use as an instrument hole. and was plugged for abandonment in 1971. Little else is known about this AOC. An "as-built" indicates a fenced area approximately $21 \mathrm{~m} \times 6.9 \mathrm{~m}$ (70 ft x $20 \mathrm{ft}$ ) (Holmes and Narver, 1969). This is possibly the site of the drilling mud reserve pit. Based on the results of 
sampling drilling mud in the REECo pits area, possible contaminates may include diesel and metals, primarily chromium and lead.

\subsubsection{Source Area 5 - Injection Well Area}

\subsection{AOC 5-A, Well HT-2}

The geophysical investigation conducted in 1992 and 1993 did not reveal the presence on any unidentifiable magnetic anomalies.

Shallow soil and groundwater samples collected during the CPT investigation activities identified low concentrations of lead and chromium. probably related to the drilling fluids (Figure 3-6). Gross alpha and beta activities exceeded the reference samples values for both water and soil samples. Several radionuclides were also identified in the soil sample (DOE, 1994c).

\subsection{AOC 5-B, Well HT-2m}

Geophysical investigations conducted in 1993 failed to identify any buried materials or reveal the presence of mud pits (DOE, 1994d). Surface soil samples collected in 1993 identified two pesticides (DDE and DDT) in one sample. Soil samples collected during the CPT investigation indicated the presence of barium. chromium. and lead above the CRDL. Gamma spectroscopy identified the presence of two radionuclides at leveis that exceeded the reference sample values (DOE, 1994c).

\subsubsection{Source Area 6 - Helicopter Pad and Storage Area}

The Helicopter Pad and Storage Area was a 1.5-hectares (3.7-acre) site located about $1,220 \mathrm{~m}$ $(4,000 \mathrm{ft})$ east of the leased area boundary on the south side of the northeast access road. The type of storage done at the site is unknown. It is not believed that any maintenance or refueling activities were conducted at this site (Personai Communication, Mr. D. Duncan, DOE-NV, 15 August, 1990); however, if such activities occurred, solvents, degreasing agents, fuels, and antifreezes may have been stored and/or used ar this site.

The results of the geophysical investigation did not reveal the presence of any anomalies (DOE, 1994d) (Figure 3-7). The results of soil sampling indicated no COC (DOE, 1994a). No further sampling or investigative activities are planned. 


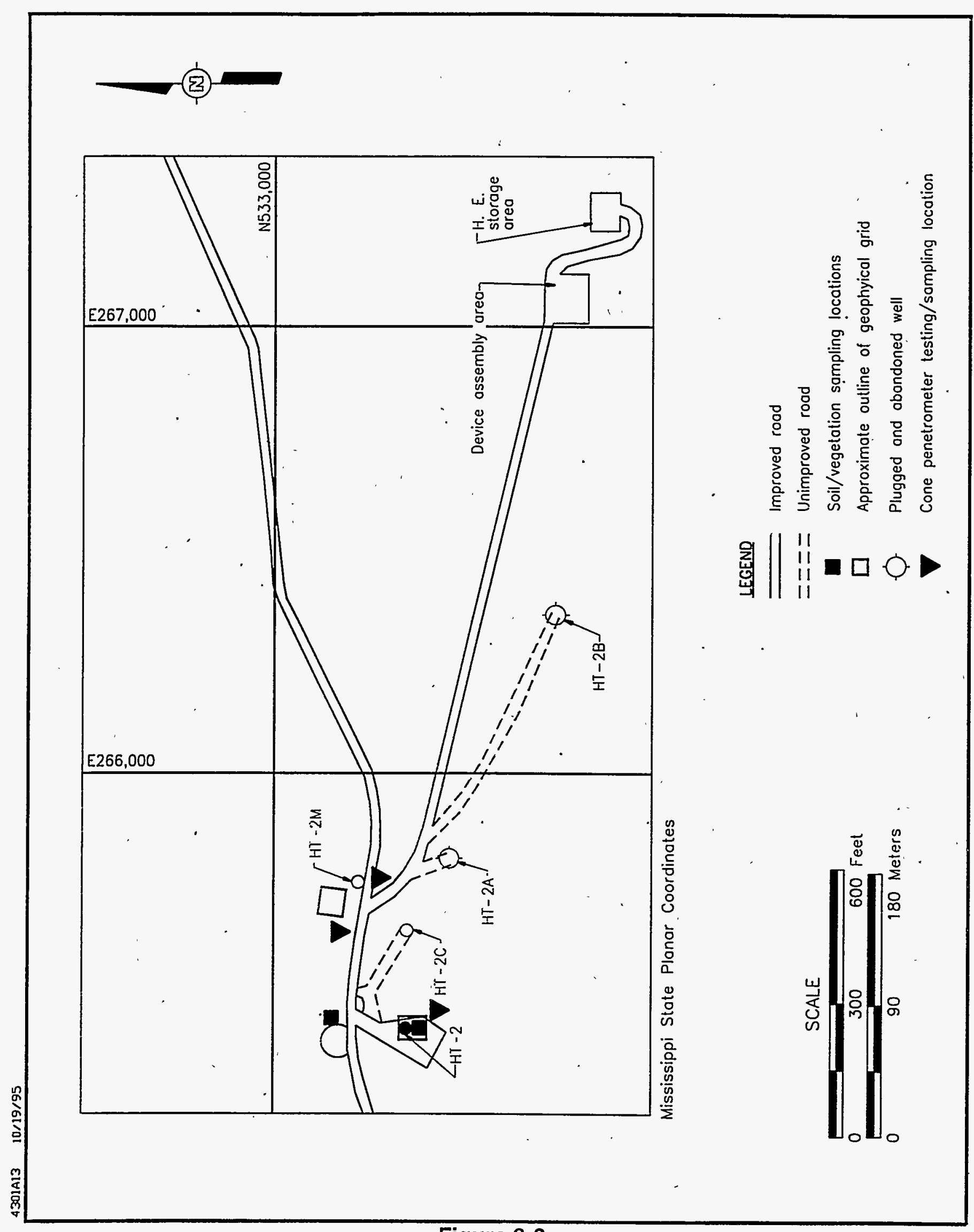

Figure 3-6

Sampling Locations in Source Area 5 


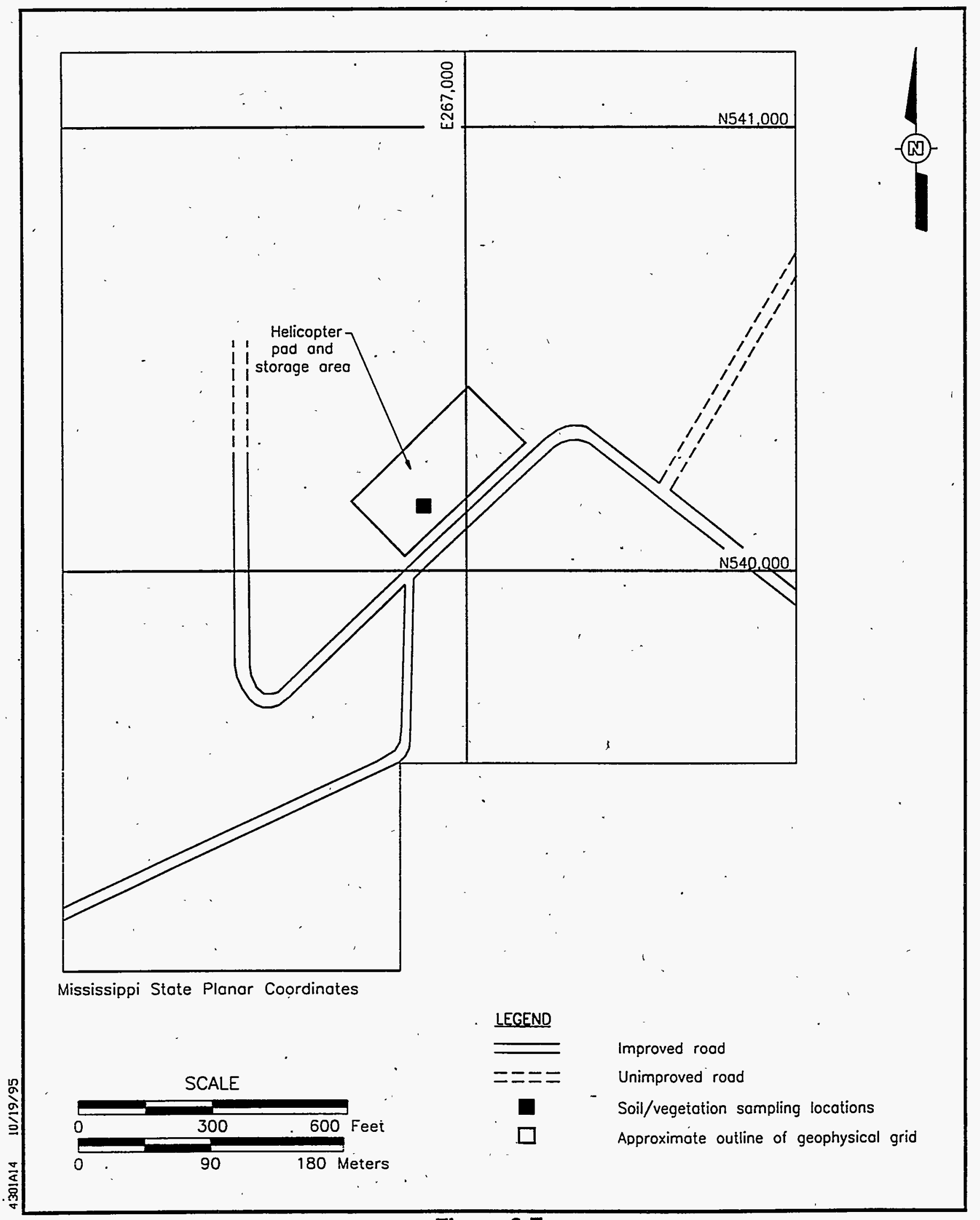

Figure 3-7

Sampling Locations in Source Area 6 


\subsubsection{Environmental Media Operable Units}

\subsubsection{Soil}

Prior to decommissioning of the SS, an extensive soil sampling and testing program was initiated to identify areas where soil contamination with radioactivity in excess of $1.0 \times 10^{-5}$ microcuries per gram existed. A total of 7,404 soil samples were raken and analyzed before and during decommissioning. This program identified six areas that were contaminated above the specified level. The following sections summarize the contamination at the sites and the actions that were taken during decommissioning to reduce risks associated with the contaminants.

The extent of contamination at some AOC was defined on the basis of antimony $\left({ }^{125} \mathrm{Sb}\right)$ concentrations in the soil. This isotope has since decayed below levels of concern (the half life of antimony-125 is 2,7 years). However, nonradiologic testing was not performed, so it was assumed that areas formerly contaminated with ${ }^{125} \mathrm{Sb}$ are the areas most likely to be contaminated with hazardous constituents due to the nature of past operations.

\subsection{E-6 Decontamination Pad}

Soils at the E-6 Decontamination Pad and the swamp area to the east of the pad were sampled in 1972. The results of this sampling indicated that ${ }^{125} \mathrm{Sb}$ contamination extended across the northern one-half of the pad and into the swamp area to the east. The original distribution of contamination at the area has probably been obscured or altered by subsequent regrading of the site. During decommissioning, a total of $1,797 \mathrm{~m}^{3}\left(2.350 \mathrm{yd}^{3}\right)$ of soil were excavated from the E-6 Decontamination Pad and adjacent swamp area for disposal in the shot cavity.

Sampling of the surface soil from the E-6 Decontamination Area in 1993 did not identify any COC (DOE, 1994a).

\subsection{E-14 Equipment Storage Pad}

Soils at the E-14 Equipment Storage Pad and the swamp area to the west of the pad were sampled in 1972. The results of this sampling indicated that ${ }^{125} \mathrm{Sb}$ contamination extended across the northeastern most part of the pad and into the swamp area to the west. The original distribution of contamination at the area has probably been removed by subsequent regrading of the site. During decommissioning, a total of $738 \mathrm{~m}^{3}\left(965 \mathrm{yd}^{3}\right)$ of soil were excavated from the E-14 Equipment Storage Pad and the adjacent swamp area and for disposal in the shot cavity. 
Soil and groundwater sampling conducted during the CPT investigation. indicated the presence of chromium, lead, barium, mercury, and nickel in both soil and water samples (DOE. 1994c).

\subsection{Bleed-Down Plant}

Soils at the Bleed-Down Plant, in the SGZ area, were sampled in 1972. Soils in the Bleed-Down Plant area exhibited patchy contamination believed to have been the result of spills, minor decontamination, and runoff from source areas.

The original distribution of contamination at the area has probably been removed by subsequent regrading of the site. During decommissioning, a total of $1,789 \mathrm{~m}^{3}\left(2,340 \mathrm{yd}^{3}\right)$ of soil were excavated from the Bleed-Down Plant area and disposed of in the shot cavity. Portions of the area, particularly in the immediate vicinity of Station 1-A, were bladed and backfilled during testing operations.

Soil samples collected in 1993 identified the presence of pesticides and PCBs (DOE. 1994a). Vegetation samples collected from the same location indicated the presence of several . radionuclides at levels exceeding those of the reference sample. Sediment samples collected from the Beaver Pond adjacent to the Bleed Down Plant, indicated elevated levels (greater than the reference sample) of lead-212, radium. and uranium. Gross alpha and beta also exceeded the reference sample values (DOE, 1994a).

\subsection{Drilling Equipment Storage Yard}

Soils at the Drilling Equipment Storage Yard were sampled in 1972. The results of these sample analyses indicated that minor contamination with ${ }^{125} \mathrm{Sb}$ occurred in the northeastern part of the yard, near the Salmon Event Postshot Drilling Storage Area and in an area along the southern boundary of the yard.

Geophysical investigations of the site indicated several small anomalies; however. no trenches were proposed (DOE. 1994d). Soil samplès collected in 1993 did not indicate any contamination although the samples did indicate elevated gross alpha activities (DOE. 1994a).

\subsection{East Parking Lot and Swamp}

The East Parking Lot was a graded surface used for parking vehicles and as roadways in the SGZ area. Patchy contamination at this site and adjacent small forested areas was caused by runoff from the adjacent Bleed-Down Plant area ánd from the decontamination of a drilling rig in the parking lot during the Salmon Event. 
Soils at the East Parking Lot and the Swamp north and east of the parking lot were sampled in 1972. The results of this sampling indicated that ${ }^{125} \mathrm{Sb}$ contamination extended across most of the parking lot and into the swamp to the north. east. and southeast of the parking lot. However. the original distribution of contamination at the area has probably been obscured by subsequent regrading of the site. During decommissioning of the SS, about $1,147 \mathrm{~m}^{3}\left(1,500 \mathrm{yd}^{3}\right)$ of soil were excavated from the East Parking Lot and disposed of in the shot cavity.

Soil samples collected in 1993, did not indicate any significant levels of contamination (see Bleed Down Plant discussion above).

\subsection{South Road Swamp Area}

The South Road Swamp Area, located about $200 \mathrm{ft}$ south of SGZ, included the slush pit and the swamp area to the east. Soils in the southern part of the slush pit and in the swamp were sampled in 1972. The results of the sampling indicated that ${ }^{125} \mathrm{Sb}$ contamination extended from the southeastern part of the slush pit and into the swamp area to the east for a distance of about $120 \mathrm{ft}$. The original distribution of contamination at the area has probably been obscured by subsequent regrading of the site. During decommissioning of the SS, about $2,293 \mathrm{~m}^{3}\left(3,000 \mathrm{yd}^{3}\right)$ of soil were excavated from the slush pit and disposed of in the shot cavity.

Samples collected in 1993 from the area near the Station IA Mud Pit indicated the presence of metals (chromium, lead, arsenic, mercury and nickel) and two volatile organic compounds (carbon disulfide and 1,2, Dichlorethane). Chromium and dichlorethane exceeded the MCL (DOE, 1994c).

\subsection{Additional AOC}

Other sites where cleanup activities occurred are discussed in the following subsections.

\section{Station I Cellar}

The Station I Cellar was abandoned because of water problems during drilling. The cellar was covered with planks and earth. Subsequently, contamination found in this cellar is believed to have been related to the operations at the adjacent Station 1-A Cellar (Brady and Milton, 1972).

Samples collected during the CPT investıgation have indicated the presence of volatiles, metals. and tritium in the shallow subsurface in the vicinity of the Station 1A Cellar (DOE. 1994c).

These contaminants are related to both the cellar and the mud and slush pits. 


\section{Blooie Tank}

The Blooie Tank was a cylindrical steel tank used for the storage of liquid radioactive effluents generated during the Salmon and Sterling Events postshot drilling operations. The contents of the tank were primarily hardened salt, cement, and stemming sand mixed with some liquid. During decommissioning, the contaminated material in the tank was transferred to open-top $208 \ell$ (55-gal) drums and transported to the shot cavity for disposal.

Following emptying, the tank was scaled and cleaned to meet shipping criteria. The residues were disposed of down the shot cavity and the tank was shipped to the NTS for disposal. Soil contamination.was found in the vicinity of the Blooie Tank. The area where the tank was located was drained by a broad ditch that channels surface runoff from the contaminated area around the tank.

\section{Station 1-A Cellar}

The Station 1-A Cellar was constructed underground immediately adjacent to the shot cavity reentry well. This cellar was built of concrete $20 \mathrm{~cm}$ (8 in.) thick, and was designed to contain the blowouc prevention system employed during the reentry drilling following the Salmon Event. Contamination encountered at Station 1-A Cellar is believed to be related to the operations at this location.

Samples collected during the CPT investigation have indicated the presence of volatiles, metals. and tritium in the shallow subsurface (DOE. 1994c). These contaminants are related to both the cellar and the mud and slush pits.

\section{West Road Spill Area}

During decommissioning, a total of $176 \mathrm{~m}^{3}\left(230 \mathrm{yd}^{3}\right)$ of contaminated soil were excavated from the West Road Spill Area and disposed of in the shot cavity.

\subsubsection{Groundwater}

The long-term monitoring that has been conducted since decommissioning of the SS has detected tritium in the shallow water table. Groundwater samples collected and analyzed in April 1990 from three monitoring wells were also found to have trace levels of contamination. The contaminants found were 1,2-Dichloroethene. benzene, naphthalene, 1-Methylnaphthalene, 2-Methylnaphthalené, and n-Nitrosodiphenyiamine. 
The extent of the groundwater contamination in 1979 is detailed in the following discussions. A 4-hectare (10-acre) area of tritiated groundwater has been delineated at SGZ. The concentration of tritium in the groundwater at this location ranged from $<300 \mathrm{pCi} / \ell$ to about $560,000 \mathrm{pCi} / \ell$. About two acres within this area were found to have groundwater with tritium concentrations above the $20,000 \mathrm{pCi} / \mathrm{l}$ MCL. Since 1979. the level of tritium has declined appreciably as a result of the natural decay of this radionuclide (tritium has a half-life of 12.3 years).

\subsubsection{Surface Water and Sediment}

Sampling conducted in 1993 did not indicate significant levels of contamination in any of the bodies of water that were sampled. Minor contamination was noted in samples collected from the Beaver Pond (DOE, 1994a).

\subsubsection{Air}

Minor levels of air emissions, primarily noble gases such as krypton and argon, may have occurred during reentry drilling operations. No detectable quantities of radionuclides were released to the air. A former worker familiar with the site reported that the drill back activities following the Salmon Event revealed that the shot cavity pressure was less than atmospheric pressure (G. Higgins, Personal communication, 1995). Volatile organic compounds, if present, could result in some emissions: however, it is unlikely that any such emissions would be at appreciable levels.

\subsubsection{Biota}

Biota sampling conductèd in 1993 indicated that no apparent contamination from site activities were present (DOE, 1994a and DOE. 1995). 


\subsection{Data Quality Objectives}

\subsection{Introduction}

In Chapters 1.0 through 3.0, background information on the SS was presented. In this section, the technical approach for the work to be performed during the RI/FS is presented. The technical approach, of the RI/FS is designed to achieve the program objectives identified in Section 4.0 of the original work plan. The RI/FS activities will be consistent with the CERCLA process and will meet those general requirements set out in the original work plan.

The organization of this section of the Work Plan addendum is based on guidance presented by EPA for the development of data quality objectives (DQO): DQOs are qualitative and quantitative constraints specified to ensure that data of known and appropriate quality are obtained during remedial response activities. To ensure that the data generated are adequate to support a regulatory decision, a clear definition of the objectives and the methods by which decisions will be made must be established early in the project planning process. The EPA has developed a seven step"process for the formulation of DQOs to ensure that data are of the correct quality, and quantity.

Discussions with the MS-DEQ and Mississippi Department of Health (MS-DOH) and the results of investigations completed thus far have identified sixteen areas that require additional data to fulfill the objectives of this RI:

- Contamination from the shot cavity

- Contamination of Aquifer 4

- Contamination at the REECo pits

- Tritium ar SGZ

- Chromium in Aquifer 3 at SGZ

- Pentachlorophenol in the Caprock and/or Aquifer 3 in Well E-7

- Tritium in the Reserve Mud Storage Area (pits) in Source Area 3

- Tritium in Disposal Pit 5 area

- Possible contamination in the Clean Burn Pit (Source Area 2) 
- Possible chromium contamination in soil where water from HM-3 has been discharged during the LTHMP sampling

- Possible contamination from drilling fluids at the E-5 well location

- Possible contamination from drilling fluids at the E-3/E-9 well location

- Possible contamination from drilling fluids at the Station 3 and Station $3 \mathrm{~A}$ vent

- Possible Contamination from drilling fluids at the E-2/E-7 well location

- Possible Contamination from drilling fluids at the W.P. 4 and Station 4 well location

- Potential contamination from a sewage disposal tank near Government Storage Area 2.

In the following sections each area is identified, the decision to be reached is stated. and the proposed methodology is discussed. Details of the work to be preformed are given in Section 5.0 of this addendum.

\subsection{Contamination from the Shot Cavity}

\subsubsection{Problem Statement}

Although the detonations in the salt dome were fully contained, concerns have been raised as to whether or not leakage from the shot cavity has occurred, contaminating the aquifers downgradient. Possible pathways for the contamination are either through pre-existing wells that were improperly plugged or where plugging is no longer effective in sealing the well bore. The areal boundary is the outer edge of the salt dome (a circle approxımately $1.6 \mathrm{~km}[1 \mathrm{mi}]$ in diameter). The vertical boundaries are the land surface and the top of the Caprock of the Salt Dome. Included within these boundaries are five aquifers. The data collected will reflect the current conditions of each aquifer. The scale of decision-making will be each individual aquifer over the salt dome. Tritium and man-made radionuclides in the groundwater in each aquifer are the COC.

\subsubsection{Identification of the Decision}

Are contaminants from the shot cavity leaking into the surrounding aquifers thereby requiring characterization and remedial action; and what direction, if any, will the contaminants move? 


\subsubsection{Design for Obtaining Data}

In order to reach the decision for this problem, groundwater monitoring points need to be established in each of the aquifers overlying the dome. Presently there is at least one monitoring point in each of the 5 aquifers that overiie the dome. At least nine additional points will be installed, two in eâch aquifer (except for Aquifer 1, which is not present southeast of SGZ). The Station 4 well will be evaluated to determine if it can be converted to a monitoring point.

Table 4-1 summarizes the existing and proposed groundwater monitoring points in the vicinity of SGZ that will be used to evaluate possible contaminant transport. The additional points will be situated to the south and southeast and provide monitoring points down gradient from SGZ. The distribution of the points is sufficient to provide accurate gradient information for each aquifer.

Table 4-1

Existing and Proposed Wells for the Surface Ground Zero Area by Aquifer

\begin{tabular}{|c|c|c|c|}
\hline Aquifer & Existing Wells & Additional Wells & Total \\
\hline \hline Local & HM-L & 2 & 3 \\
\hline 1 & HT-4, HM-1 & 1 & 3 \\
\hline $2 a$ & HM-2a, HT-5 & 2 & 4 \\
\hline $2 b$ & HM-2b & 2 & 3 \\
\hline 3 & HM-3, E-7 & $3^{a}$ & 5 \\
\hline
\end{tabular}

${ }^{a}$ This presumes that the Station 4 well can be converted to a monitoring well.

Once monitoring wells are installed, the groundwater will be sampled for tritium. gross alpha and beta activity, and gamma spectroscopy to determine if man-made radionuclides are present. In addition, samples will be collected for metals analysis from Aquifer 3 (see Section 4.9). Water levels will be determined for each of the aquifers in the new wells and compared to water levels in existing wells to define the potentiometric surface and determine the direction of flow.

The new wells will be incorporated into the LTHMP conducted by the EPA. 


\subsection{Contamination of Aquifer 4}

\subsubsection{Statement of Problem}

Well HT-2, located in Source Area 5 Injection Well Area, was used for the injection of radioactively contaminated water. Prior to injection of the waste, $7.57 \mathrm{~m}^{3}(2,000 \mathrm{gal})$ of 15-percent hydrochloric acid were injected to increase the effective porosity and permeability of the Cook Mountain Limestone (Aquifer 5). Following the acid treatment, $128 \mathrm{~m}^{3}$ (33,900 gal) of radioactively contaminated water were injected into the well. The waste had a total activity of 38 curies of beta-gamma emitters and 3,253 curies of tritium. Following injection of the waste, an additional $340 \mathrm{~m}^{3}(90,000 \mathrm{gal})$ of fresh water were injected. Concerns have been raised by the MS-DEQ that the waste fluids injected into Aquifer 5 may be migrating into the overlying aquifers through pathways that are a result of inadequate plugging of the HT-2 well or through the clay aquitard between Aquifers 4 and 5. The area of concern is Aquifer 4 in a circle with a radius of $76 \mathrm{~m}$ ( $250 \mathrm{ft}$ ) around HT-2. The data collected will allow determination as to whether the wastes are migrating from Aquifer 5 and will reflect the current condition of the groundwater in Aquifer 4.

\subsubsection{Identification of the Decision}

If contaminants are migrating from Aquifer 5 into Aquifer 4, are they also migrating into * Aquifer 3. thereby requiring further characterization and remedial action.

\subsubsection{Design for Obtaining Data}

In order to reach the decision for this problem. groundwater monitoring points need to be established in Aquifer 4. One well will be installed up gradient (northeast) and one well down gradient of well HT-2. These wells will allow the sampling of Aquifer 4 for tritium and man-made radionuclides and the new wells will be incorporated into the LTHMP. If radionuclides are detected in Aquifer 4, then additional wells will be installed in Aquifer 3 .

\subsection{Source Area 2; AOC 2-A: Contamination at the Reynolds Electrical \& Engineering Co., Inc. Pits}

\subsubsection{Statement of the Problem}

Results of trench sampling in the REECo pits indicate the presence of TPH and metals within drilling fluids disposed of in the pits during and following site operations. One of pits contains furan compounds. The REECo pits encompass approximately 6 hectares ( 15 acres) in the northern disposal area. Saturated sediments have been identified at a depth of $3 \mathrm{~m}(10 \mathrm{ft})$ below 
ground surface, however, the lateral continuity of this interval is not known. The vertical extent of the contamination is not known. nor are the potential ecological impacts and possible health threats to occasional site visitors.

\subsubsection{Identification of the Decision}

- Determine if contamination is migrating from the REECo pits into surrounding areas at levels that exceed regulatory limits, thereby requiring characterization and remedial action.

- Determine the vertical and area extent of the potential contamination.

- Determine whether contaminants pose a threat to site personnel, occasional visitors, and/or the ecology, based on soil clean-up standards (IRIS).

\subsubsection{Design For Obtaining Data}

Based on the results of the CPT investigation and trench sampling, the contamination appears to be restricted to within 6.1 to $7.6 \mathrm{~m}$ ( 20 to $25 \mathrm{ft}$ ) of the surface. The shallow, water-bearing units do not appear to be continuous across the REECo Pits area and any groundwater flow is likely to follow the topography. In order to determine the areal extent of contamination. a systematic random sampling of the shallow subsurface is proposed for the area to the south and west of the REECo pits area. Seven to eight samples are recommended for analysis of metals (Toxicity Characteristic Leaching Procedure), TPH (diesel) and dioxin/furans. Additional data is also required to determine the lateral continuity of water bearing units beneath the pits area. Three auger borings are recommended to collect this data.

\subsection{Tritium at Surface Ground Zero}

\subsubsection{Statement of Problem}

There are two subparts to this problem: (1) the groundwater in the HMCAA around SGZ has been contaminated with tritium as a result of migration from the slush pits associated with Postshot Drilling activities and (2) mud pits constructed during drilling operations may contain radionuclides other than tritium. Chromium and lead have also been identified. The vertical and areal extent of this contamination is unknown. as is the potential for migration from SGZ and the potential impacts to the ecology and human health.

The total surface area affected around SGZ is approximately 4 hectares ( 10 acres) mostly to the north and west of SGZ: Groundwater in the vicinity is very shallow and susceptible to seasonal 
fluctuations. During periods of rain, the HMCAA probably discharges into Half Moon Creek. The base of the HMCAA is approximately $9 \mathrm{~m}(30 \mathrm{ft})$ below ground surface. Sampling may be limited by the presence of wetlands. Each of the mud pits covers approximately 0.1 hectare $\left({ }^{1} 4 \mathrm{acre}\right)$ and is estimated to be no more than $6.1 \mathrm{~m}(20 \mathrm{ft})$ deep.

\subsubsection{Identification of the Decision}

The extent to which tritium has migrated from SGZ mud and slush pits into the groundwater and surface waters needs to be determined. Based on these results, determine if remediation is required. Determine the vertical extent of contamination associated with the mud and slush pits. Determine if radiological constituents other than tritium are present.

\subsubsection{Design for Obtaining Data}

In order to reach the decision for this problem, additional groundwater monitoring points need to be established in the HMCAA. Presently, there are 16 monitoring wells within a $300-\mathrm{m}$ (1,000-ft) radius of SGZ installed in the HMCAA. Seven additional wells are proposed for the SGZ area which will provide additional data about possible contamination in the HMCAA at locations south and east of SGZ. Samples will be collected and analyzed for metal. tritium, and man-made radionuclides.

Samples need to be collected from the base of the slush and mud pits. This can be accomplished through the use of an auger and split spoon sampler. Samples need to be collected from the base of the pits and below to determine the vertical extent of contamination. These samples will be analyzed for tritium, man-made radionuclides, and those COC identified in the CPT investigation. The sampling plan for the wells proposed in (a) can be modified to include those COC identified in this portion of the investigation.

\subsection{Chromium in Aquifer 3 at Surface Ground Zero}

\subsubsection{Statement of Problem}

In 1979, well HM-3 was installed into Aquifer 3 near SGZ. Aquifer 3 is a potable warer source * in the region surrounding the site. In 1993, samples collected from this well indicated the presence of chromium in the water sample. Subsequent sampling indicated that only chrome III was present in the water. The extent of this contamination is unknown, although it is assumed to be confined to Aquifer 3. It needs to be determined whether the chromium in Aquifer 3 is migrating off site. 


\subsubsection{Identification of the Decision}

Determine if the chromium in Aquifer 3 is migrating off site, thereby requiring remediation.

\subsubsection{Design for Obtaining Data}

Water level data obtained from the installation of the monitoring wells in Problem 1

(Section 4.2.3) can be used to determine the flow direction for Aquifer 3. Water samples collected from Aquifer 3 will also be routinely analyzed for chromium to ensure that it is not migrating off site. A sustained pumping of well HM-3 should also be undertaken to determine if the chromium concentrations diminish with time.

\subsection{Pentachlorophenol in the Caprock Aquifer}

\subsubsection{Statement of the Problem}

Routine sampling of the E-7 well indicated the presence of PCP at 140 micrograms per liter. The source of the PCP is unknown as is the vertical and areal extent of the contamination. None of the information about operations at the SS indicates that PCP was used. It is suggested here that the contamination was introduced from the surface and the Design for Data Acquisition (Section 4.7.3) operates from this premise. A well completion schematic indicates that the annulus is not completely cemented to the surface and that the Caprock Aquifer is separated from Aquifer 3 by a sand plug. The well may be completed in both the Caprock Aquifer and Aquifer 3 (Medley, 1972).

\subsubsection{Identification of the Decision}

Determine the vertical and areal extent of the contamination in the Caprock and/or Aquifer 3 to determine if it requires remediation.

\subsubsection{Design for Obtaining Data}

Water samples need to be collected from several depths within the water column in well E-7 to determine the vertical distribution of the PCP. Field test kits for PCP will be used to determine approximate concentrations. Then at least three well casing volumes will be purged from the well and the well will be resampled. If no further PCP is identified by the field screening techniques, a confirmatory sample will be collected. Because this well is a key sample point, actions need to be taken to ensure its long term useability and data integrity. Presently the well has no sampling pump and the integrity of the casing is unknown. Following sampling activities, the well casing needs will be inspected, repaired if necessary, and a sampling pump installed. 


\subsection{Tritium in the Mud Storage Pits}

\subsubsection{Statement of the Problem}

Two pits were constructed in Source Area 3 for the purpose of storing drilling mud. Geophysical surveys defined the lateral extent of the pits. Water samples collected from one of the pits during the CPT investigation had tritium activity of $1,540 \mathrm{pCi} / \mathrm{c}$. The source, areal and vertical extent of the tritium contamination is unknown.

\subsubsection{Identification of the Decision}

Determine the vertical and areal extent of the mud pits. Determine if there are radiological constituents other than tritium in the reserve mud pits, thereby requiring remediation.

\subsubsection{Design for Obtaining Data}

Although the geophysical investigations were effective in defining the areal extent of the pits, additional information is necessary to determine the vertical extent of the pits and possible contamination. Auger borings and split spoon samples from the base of the pits and below will serve to define the vertical extent of contamination. The samples will be analyzed for tritium. gross alpha and beta activity, and by gamma spectroscopy for man-made radionulcides, TPH (diesel), and metals (total). Two monitoring wells are proposed for installation in the down gradient direction to determine if contamination has migrated from the location.

\subsection{Tritium in Disposal Pit 5 Area}

\subsubsection{Statement of the Problem}

Sampling of the drainage through the REECo pits has historically indicated tritium concentrations on the order of 1,000 to $2,000 \mathrm{pCi} / \ell$; however, in 1983 tritium was detected at $12,000 \mathrm{pCi} /$. 'Sampling results since that time have indicated a return to historical values. Local lore has suggested that waste was containerized in drums and buried in this area; however, geophysical surveys and trenching activities have failed to support this. Because no logical explanation can be found for the anomalous tritium value, the source of the tritium needs to be identified.

\subsubsection{Identification of the Decision}

Determine the source of tritium in disposal pit 5 (REECo pits) and whether it requires further characterization and remediation. 


\subsubsection{Design for Obtaining Data}

Sample the drainage run-off during or immediately following a heavy rain. Samples will be collected at the point where the natural drainage enters the REECo Pits and where the drainage leaves the pits area. Surface water and shallow subsurface water samples will be collected from both locations and analyzed for tritium activity.

\subsection{Possible Contamination in the Clean Burn Pit (Source Area 2)}

\subsubsection{Statement of the Problem}

Because contaminants that resulted from burning of waste were found in the debris burial pits in Source Area 2, concerns have been raised that furan compounds may also be present in the clean burn pit. Geophysical investigations did not serve to identify the boundaries of the burn pit so the areal and vertical extent of the pits are unknown. Because of proximity of Half Moon Creek and the shallow depth to groundwater. this site may pose a risk to the ecology and human health.

\subsubsection{Identification of the Decision}

Confirm the existence of this pit and determine if there are furans or other contaminants in the clean burn pit that require characterization and possible remedial action.

\subsubsection{Design for Obtaining Data}

Initially auger boring and split spoon sampling are proposed for investigation of this sire. If contamination is identified, then a more detailed auger sampling program needs to be designed. If no contaminants are found and there is no conclusive evidence that the pit existed. then a decision needs to be made whether to pursue this further or conclude that the site never existed. was never used. or was mislocated on the map.

\subsection{Possible.Chromium in Soil from HM-3 Purge Water}

\subsubsection{Statement of the Problem}

The HM-3 well is part of the LTHMP network established by the DOE and administered by the EPA. Purge water is routinely discharged to the surface (see problem 4.6). The extent to which this practice has contaminated the surface and shallow sub surface in the vicinity of HM-3 is unknown. The area affected is approximately 18.5 square meters ( 200 square $\mathrm{ft}$ ) to an estimated depth of $.3 \mathrm{~m}(1 \mathrm{ft})$. 


\subsubsection{Identification of the Decision}

Determine whether there is chromium in the soils where the purge water from well HM-3 has been discharged.

\subsubsection{Design for Obtaining Data}

Establish a grid covering the area where the discharge occurred. Conduct systematic random sampling of the area to collect seven soil samples to a depth of approximately $.5 \mathrm{~m}$ (18 in.).

\subsection{Possible Contamination from Drilling Fluids at the E-5 Well Location}

\subsubsection{Statement of the Problem}

Well E-5 was drilled as an exploratory well during investigation of the Tatum Salt Dome, prior to testing. A mud pit was constructed to the east of the well. Based on knowledge of practices common at the site, the mud pit is suspected to contain contaminants from residual drilling mud.

\subsubsection{Identification of the Decision}

Determine whether contamination by residual drilling mud is present and. if so. the areal extent of the contamination. Compare these results to the MCLs to determine if further characterization and remedial action is required.

\subsubsection{Design for Obtaining Data}

The location of the former pit can be approximately determined from as-builts. Geophysical techniques will be used to determine its location. Initially an auger boring ànd split spoon sampling will be conducted if the pit can be identified. Field screening techniques may be used to identify potential contaminants. If contamination is encountered, additional sampling will be conducted to determune the nature and extent of contamination.

\subsection{Possible Contamination from Drilling Fluids at the E-3/E-9 Well Location}

\subsubsection{Statement of the Problem}

Wells E-3 and E-9 were drilled as exploratory wells during investigation of the Tatum Salt Dome, prior to testing. A mud pit was constructed to the east of the wells. Based on knowledge of practices common at the site, the mud pit is suspected of containing contaminants from residual drilling mud. 


\subsubsection{Identification of the Decision}

Determine whether contamination by residual drilling mud is present, and if so, the areal extent of the contamination. Compare these results to the MCLs to determine if further characterization and remedial action is required.

\subsubsection{Design for Obtaining Data}

The location of the pits can be determined only approximately from as-built diagrams. Surface geophysical investigations are needed to further define the pit location(s). Upon completion of the geophysics, if the pits can be identified, auger borings and split spoon sampling will be conducted to determine if there is contamination in the subsurface beneath the pits. Field screening techniques may be used to identify potential contaminants. If contamination is encountered, additional sampling will be conductèd to determine its nature and extent.

\subsection{Possible Contamination from Drilling Fluids at the Station 3 and Station 3A Vent}

\subsubsection{Statement of the Problem}

Two large diameter shafts were drilled in Source Area 4 as part of the construction activities at the SS. In conjunction with this work, two mud pits were constructed west of the well locations. Based on knowledge of practices at the site, these pits are suspected of containing residual drilling fluid. The areal and vertical extent of the pits and possible contamination is unknown. Based on historical records, the areal extent of the pits is approximately .30 hectare ( $3 / 4$ acre).

\subsubsection{Identification of the Decision}

Determine, whether contamination by residual drilling mud is present and the extent of contamination. Compare the results of sampling to the MCLs to determine if further characterization and remedial action are necessary.

\subsubsection{Design for Obtaining Data}

The existence and location of the pits have been established from historical information. Initially, auger borings and split spoon sampling will be conducted to determine if there is contamination in the subsurface beneath the pit. Field screening techniques may be used to Identify potential contaminants. If contamination is encountered, additional sampling will be conducted to determine its nature and extent. 


\subsection{Possible Contamination from Drilling Fluids at the E-2/E-7 Well Locations}

\subsubsection{Statement of the Problem}

Wells E-2 and E-7 were drilled as exploratory wells during investigation of the Tatum Salt Dome. prior to testing. A mud pit was constructed to the west of the wells. Based on knowledge of practices common at the site, the mud pit is suspected of containing contaminants from residual drilling mud.

\subsubsection{Identification of the Decision}

Determine whether contamination by residual drilling mud is present and the extent of contamination. Compare the results of sampling to the MCLs to determine if further remedial characterization and remedial action are necessary.

\subsubsection{Design for Obtaining Data}

The existence and location of the pits have been established from historical information. Initially auger borings and split spoon sampling will be conducted to determine if there is contamination in the subsurface beneath the pit. Field screening techniques may be used to identify potential contaminants. If contamination is encountered, additional sampling will be conducted to determine its nature and extent.

\subsection{Possible Contamination from Drilling Fluids at the W.P. 4 and Station 4 Well Location}

\subsubsection{Statement of the Problem}

Wells W.P. 4 and Station 4 were drilled as exploratory or test wells during investigation of the Tatum Salt Dome, prior to the Salmon Event. A mud pit was constructed to the east of the wells. Based on knowledge of practices common at the site, the mud pit is suspected of containing contaminants from residual drilling mud.

\subsubsection{Identification of the Decision}

Determine whether contamination by resıdual drilling mud is present, and if so, the extent of contamination. Compare the results of sampling to the MCLs to determine if further characterization and remedial action are necessary. 


\subsubsection{Design for Obtaining Data}

The location of the pits can be determined only approximately from as-builts. Surface geophysical investigations will be used to further define the pit location(s). Upon completion of the geophysics, auger borings and split spoon sampling will be conducted to determine if there is contamination in the subsurface beneath the pits. Field screening techniques may be used to identify potential contaminants. If contamination is encountered, additional sampling will be conducted to determine the nature and extent of contamination.

\subsection{Potential Contamination from a Sewage Disposal System near Government Storage Area 2}

\subsubsection{Statement of the Problem}

Historical evidence suggests that a sewage disposal tank was present during operations at the site. It is uncertain if the tank was removed during site clean up operations.

\subsubsection{Identification of the Decision}

Determine if the tank is present and if contamination has resulted.

\subsubsection{Design for Obtaining Data}

Because the existence of the sepric tank is suspected and its precise location unknown, additional surface geophysical investigations will need to be conducted to confirm its existence. If the tank is located, soil samples will be collected by auger boring and split spoon sampler. The samples will be analyzed for the chemical COCs identified in Table 4-2. the Radiological Parameters identified in Table 4-3. gross alpha activity, gross beta activity, and tritium. 
Table 4-2

Nonradioactive Water and Soil Analyses Constituents of Concern

(All 1988 Organics and 1990 Metals)

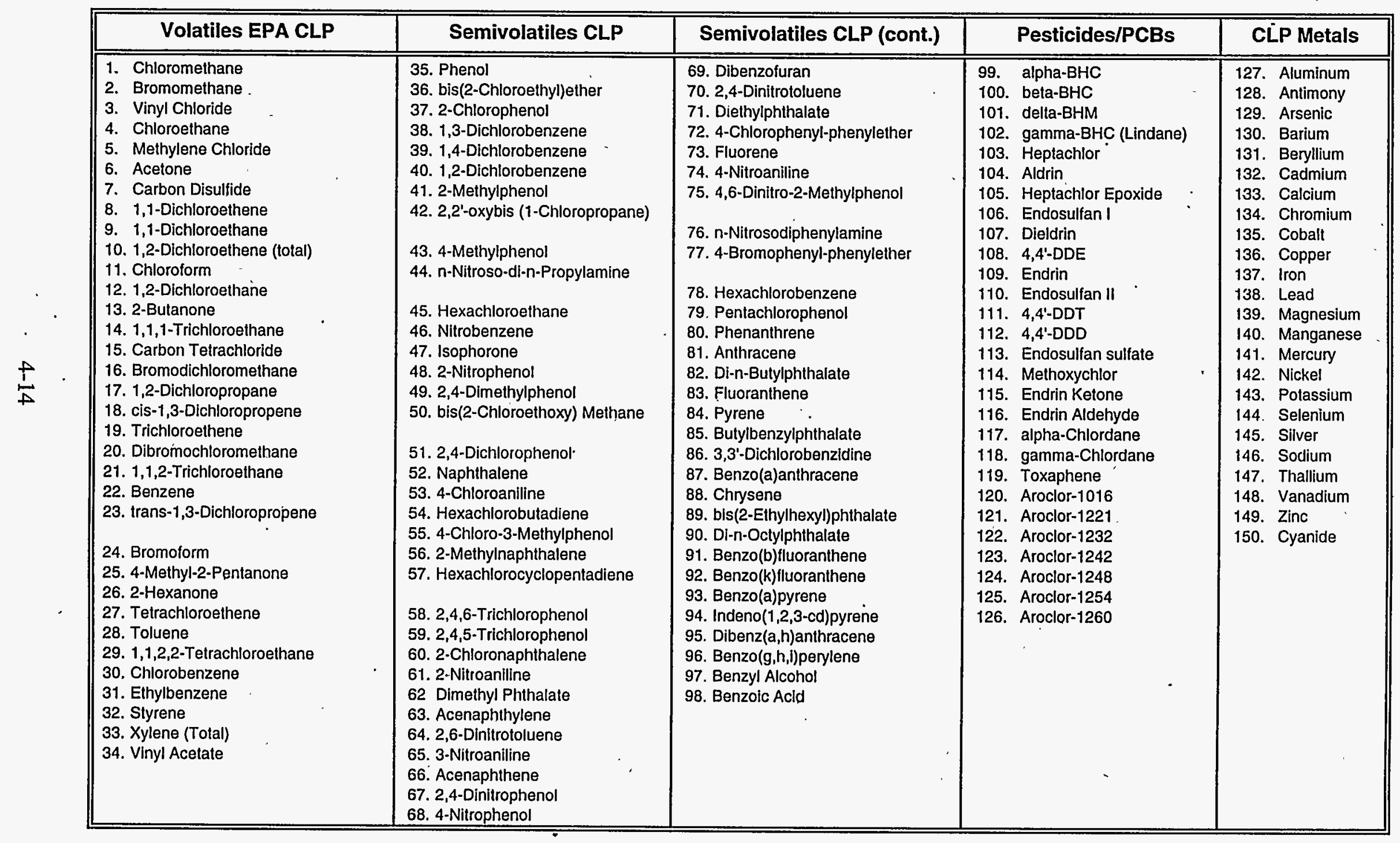


Table 4-3

Radionuclide List for Gamma Spectroscopy

\begin{tabular}{|c|c|c|c|c|c|}
\hline Radionuclide & Symbol & Radionuclide & Symbol & Radionuclide & Symbol \\
\hline Berylium 7 & $\mathrm{Be}-7$ & Ruthenium & Ru-106 & Iridium 192 & $\mid r-192$ \\
\hline Sodium 22 & $\mathrm{Na}-22$ & Silver $110 \mathrm{M}$ & $\mathrm{Ag}-110$ & Mercury 203 & $\mathrm{Hg}-203$ \\
\hline Sodium 24 & $\mathrm{Na}-24$ & Cadmium 109 & $C d-109$ & Thallium 208 & TI-208 \\
\hline Potassium 40 & $\mathrm{~K}-40$ & $\operatorname{Tin} 113$ & Sn-113 & Lead 210 & $\mathrm{~Pb}-210$ \\
\hline Scandium 46 & Sc-46 & Antimony 124 & Sb-124 & Lead 211 & $\mathrm{~Pb}-211$ \\
\hline Vanadium 48 & $V-48$ & Antimony 125 & Sb- 125 & Lead 212 & $\mathrm{~Pb}-212$ \\
\hline Chromium 51 & Cr-51 & lodine 129 & $1-129$ & Bismuth 207 & Bi-207 \\
\hline Manganese 54 & Mn-54 & lodine 131 & $\mid-131$ & Bismuth 212 & $\mathrm{Bi}-212$ \\
\hline Iron 59 & $\mathrm{Fe}-59$ & lodine 133 & $1-133$ & Bismuth 214 & $\mathrm{Bi}-214$ \\
\hline Cobalt 56 & Co-56 & Cesium 134 & Cs-134 & Radium 223 & Ra-223 \\
\hline Cobalt 57 & Co-57 & Cesium 137 & Cs-137 & Radium 224 & Ra-224 \\
\hline Cobalt 58 & Co-58 & Barium 131 & $\mathrm{Ba}-131$ & Radium 226 & Ra-226 \\
\hline Cobalt 60 & Co-60 & Barium 133 & Вa-133 & Radium 228 & Ra-228 \\
\hline Nickel 65 & $\mathrm{Ni}-65$ & Barium 140 & Ba-140 & Actinium 227 & Ac-227 \\
\hline Zinc 65 & $\mathrm{Zn}-65$ & Lanthanum & La-140 & Thorlum 228 & Th-228 \\
\hline Selenıum 75 & Se-75 & Cerium 139 & Cé-139 & Thorium 230 & Th-230 \\
\hline Strontium 85 & Sr-85 & Cerium 141 & $\mathrm{Ce}-141$ & Thorium 234 & Th-234 \\
\hline Yttrium 88 & $Y-88$ & Cërium 144 & $\mathrm{Ce}-144$ & Proactinium & $\mathrm{Pa}-231$ \\
\hline Zirconium 95 & $\mathrm{Zr}-95$ & Europium 152 & Ėu-152 & Proactinium & $\mathrm{Pa}-234$ \\
\hline Niobium 95 & $\mathrm{Nb}-95$ & Europium154 & Eu-15i & Uranium 234 & $U-234$ \\
\hline Technetium 99m & Tc-99M & Europium 155 & Eu-155 & Uranium 235 & U-235 \\
\hline Ruthenium 103 & $R u-103$ & Gadolinium & Gd-153 & Americium & Am-241 \\
\hline
\end{tabular}




\subsection{Remedial Investigation Tasks}

This section of the Work Plan addendum describes the management of the RI/FS and the scope of activities for the RI/FS based on phase, task, and subtask activities that will be implemented (see Section 5.0 of the original work plan for a complete discussion). The organization of the activities is in accordance with EPA's Guidance for Conducting Remedial Investigations and Feasibility Studies Under CERCLA (EPA, 1988). The data collected and the analyses performed during these activities will meet the DQOs identified in Section 4.0.

\subsection{Detailed Site Characterization}

This task includes installation and sampling of additional groundwater monitoring wells, a more comprehensive soil sampling program. test pit excavation, drum sampling (if required), additional geophysical investigations, aquifer testing, as required. and a comprehensive sampling round of groundwater from all existing wells. The information from these programs will be used to characterize areas identified during the Preliminary Site Characterization.

\subsubsection{Shallow and Deep Groundwater Monitor Well Installation}

These subtasks consist of the installation and testing of groundwater monitoring wells in the surficial and local aquifers at each source area identified during the Preliminary Site Characterization as a likely area of groundwater contamination. These wells will be sampled. and depending upon the results, some or all of these wells will be incorporated into the LongTerm Hydrologic Monitoring Program conducted by EPA. In addition, groundwater monitoring wells will be installed in the Local Aquifer and Aquifers 1, 2. and 3 at Source Area 1 and in Aquifer 4 at Source Area 5.

The objectives of these subtasks are to define the nature. magnitude, and extent of contamination in the surficial and local aquifers, and to assess the potential for cross contamination between the deeper aquifers at Source Areas 1 and 5 (SGZ and the Injection Well Area).

Table 5-1 lists the source area, site of wells to be installed, the number of wells, their depth. and aquifer in which they will be completed. 
Table 5-1

Planned Groundwater Monitoring Wells Salmon Site

\begin{tabular}{|c|c|c|c|c|}
\hline Source Area & Site & $\begin{array}{l}\text { Number of } \\
\text { Wells }\end{array}$ & $\begin{array}{l}\text { Approximate } \\
\text { Depth }^{\mathrm{a}} \\
\text { meters (feet) }\end{array}$ & Aquifer(s) \\
\hline \multirow[t]{3}{*}{1} & $S G Z^{b}$ & 5.: & $12(40)$ & HMCAA \\
\hline & E-14 Pad & 2 & $12(40)$ & HMCAA \\
\hline & Shot Cavity ${ }^{c}$ & $4\left(1^{d}\right)$ & $280(930)$ & Local, $2,2 \mathrm{a}$,. and 3 \\
\hline 2 & REECo Pits & 4 & $61(200)$ & LOCAL \\
\hline \multirow[t]{3}{*}{3} & Mud Storage Area & 2 & $21(70)$ & HMCAA \\
\hline & Station 4 WP-4 & 2 & $12(40)$ & HMCAA. \\
\hline & Shot Cavity ${ }^{c}$ & $5\left(1^{d}\right)$ & $290(950)$ & Local, $1,2,2 a$, and 3 \\
\hline 4 & Reserve Mud Pits & 2 & $15(50)$ & HMCAA \\
\hline \multirow[t]{2}{*}{5} & HT-2 Well & 3 & $11(35)$ & Citronelle \\
\hline & HT-2 Well & 2 & $640(2,100)$ & Aquifer 4 \\
\hline
\end{tabular}

\footnotetext{
${ }_{\text {Baelow ground surface }}$

${ }^{b}$ As used here, SGZ includes the shallow subsurface under the SGZ area which consists of Station 1-A Mud Pits. P.S.-1 Slush Pit and Mouse Hole. Bleed Down Plant and P.S. 2 Mud Pit.

Although Site 1-A includes the Shot Cavity, it is identified separately here because the method of investigation is different. The second well is physically located in Source Area 3 and is included in that heading.

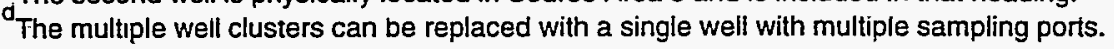

All wells will be installed in strict accordance with the specific methods detailed in the SAP, approved procedures, associated Field Operating Procedures. and the QAPP. Following installation. the location and elevation of each well will be surveyed and water levei measurements taken. Water level monitoring will be performed to determine the directions of groundwater flow beneath the source area.

\subsubsection{Source Area'1 - Surface Ground Zero}

Ongoing sampling from existing groundwater monitoring wells and discrete sampling events in the vicinity of SGZ have indicated the presence of contamination in some groundwater samples collected from the HMCAA (DOE, 1994a, 1994c; MS-DOH, 1990. 1991, 1992, 1993, and 1994). The objective of monitor well installation at this site is to provide a means to sample groundwater from the HMCAA. These wells will allow further definition of the nature. magnitude, and extent (vertical and lateral) of potential contamination in the HMCAA to 
determine if the contamination at this site poses risks to human health and the environment. By collecting this information, decisions can be made regarding possible remedial actions.

Approximately five shallow wells ( $<15 \mathrm{~m}[<50 \mathrm{ft}]$ ) will be installed in to the HMCAA in the vicinity of SGZ and 2 wells at the site of the E-14 wells (Figure 5-1). Soil and water samples collected during drilling will be analyzed for tritium. man-made radionuclides. and chemical contaminants identified during the preliminary and $\mathrm{CPT}$ investigations.

The proposed well location were selected to optimize the data collected concerning groundwater flow directions, and extent of potential contamination of the HMCAA. Input from the geophysical and CPT investigations was also used in determining the well locations. The proximity of sensitive areas (wetlands) was also a factor.

\subsubsection{Source Area 1 - Shot Cavity}

Two wells will be installed to investigate the deeper aquifers (Local, 1, 2, 2a, and 3). The purpose of these wells will be to assess the potential for cross contamination between the deeper aquifers. These data will be used to confirm that no contamination is leaking from the shot cavity into the overlying aquifers. The wells will also be used to determine flow directions of the groundwater in each of the aquifers. These wells are located away from SGZ. One well will be located in Source Area 3, approximately $457 \mathrm{~m}$ (1,500 ft) south of SGZ, and the second will be located southeast of SGZ across Grantham Creek. approximately $488 \mathrm{~m}(1,600 \mathrm{ft})$ from SGZ. Samples of water and drilling cuttings collected during the drilling of theses wells will be analyzed for tritium and man-made radionuclides.

\subsubsection{Source Area 2 - Reynolds Electrical \& Engineering Co., Inc. Disposal Pits} Four wells are planned for completion into the Local Aquifer. Three wells will be drilled down gradient and one up gradient from the REECo pits area (Figure 5-2). The purpose of these wells is to investigate possible groundwater contamination introduced to the aquifer from the REECo Pits.

\subsubsection{Source Area 3}

A total of five groundwater monitoring wells are planned for this Source Area (Figure 5-3). Four of the wells are intended to investigate the shallow aquifer to determine the nature and extent of contámination related to surface activities -primarily drilling mud and related activities. The fifth well is planned to evaluate possible contamination from the shot cavity and is planned for this source area to provide better spatial control. 


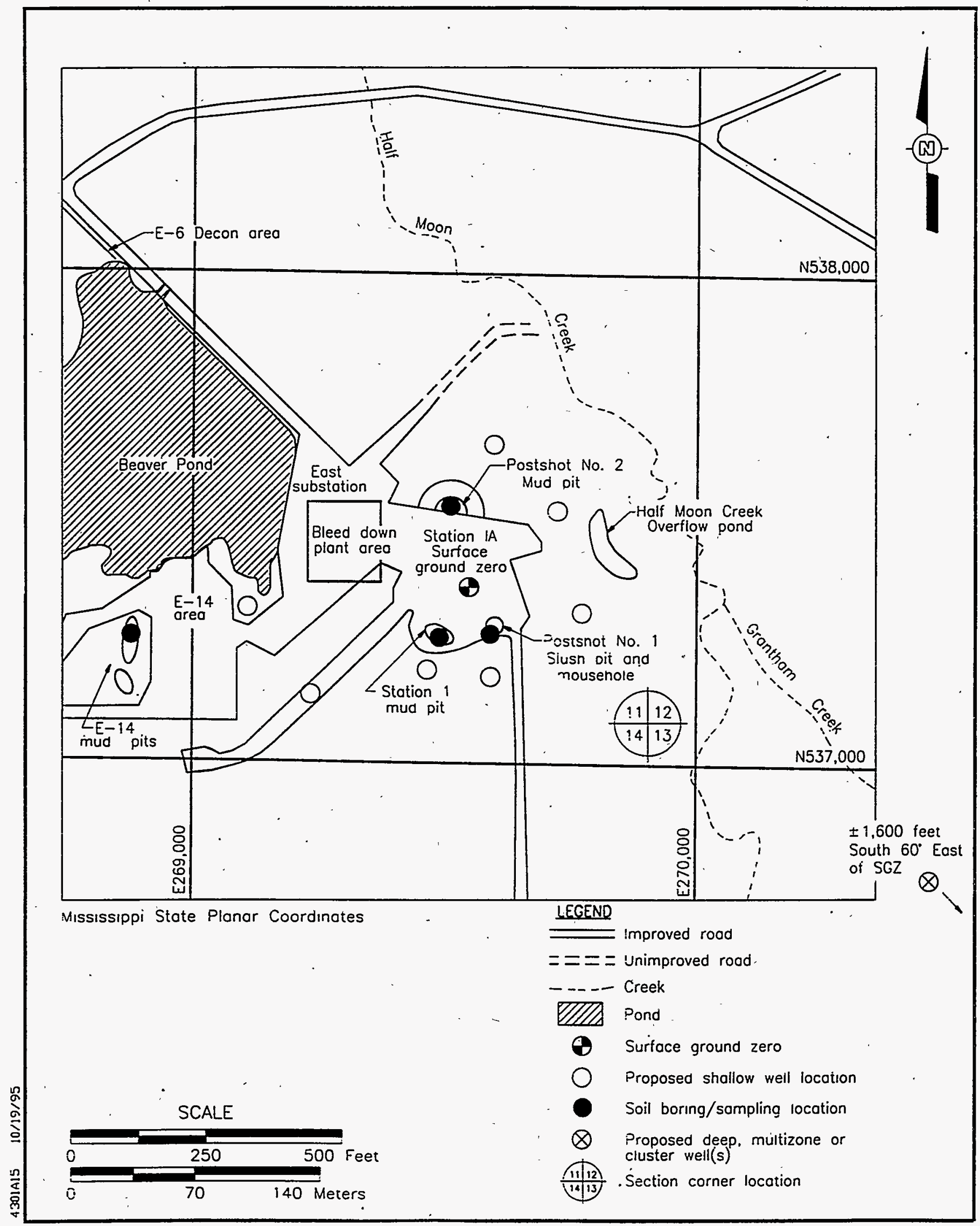

Figure 5-1

Planned Monitoring Well and Soil Boring Locations in. Source Area 1 


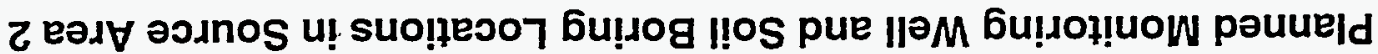

\section{Z-s əan6!}

uo!foso| bu!duos/bu!joq !!OS Uolfosol flam Dasodosd

I!d unnq uorjo

I!d jo!ng suqao

Daso josods!p pud MOدjog

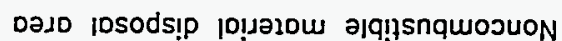

$$
\text { комроол рәлолdш }=
$$

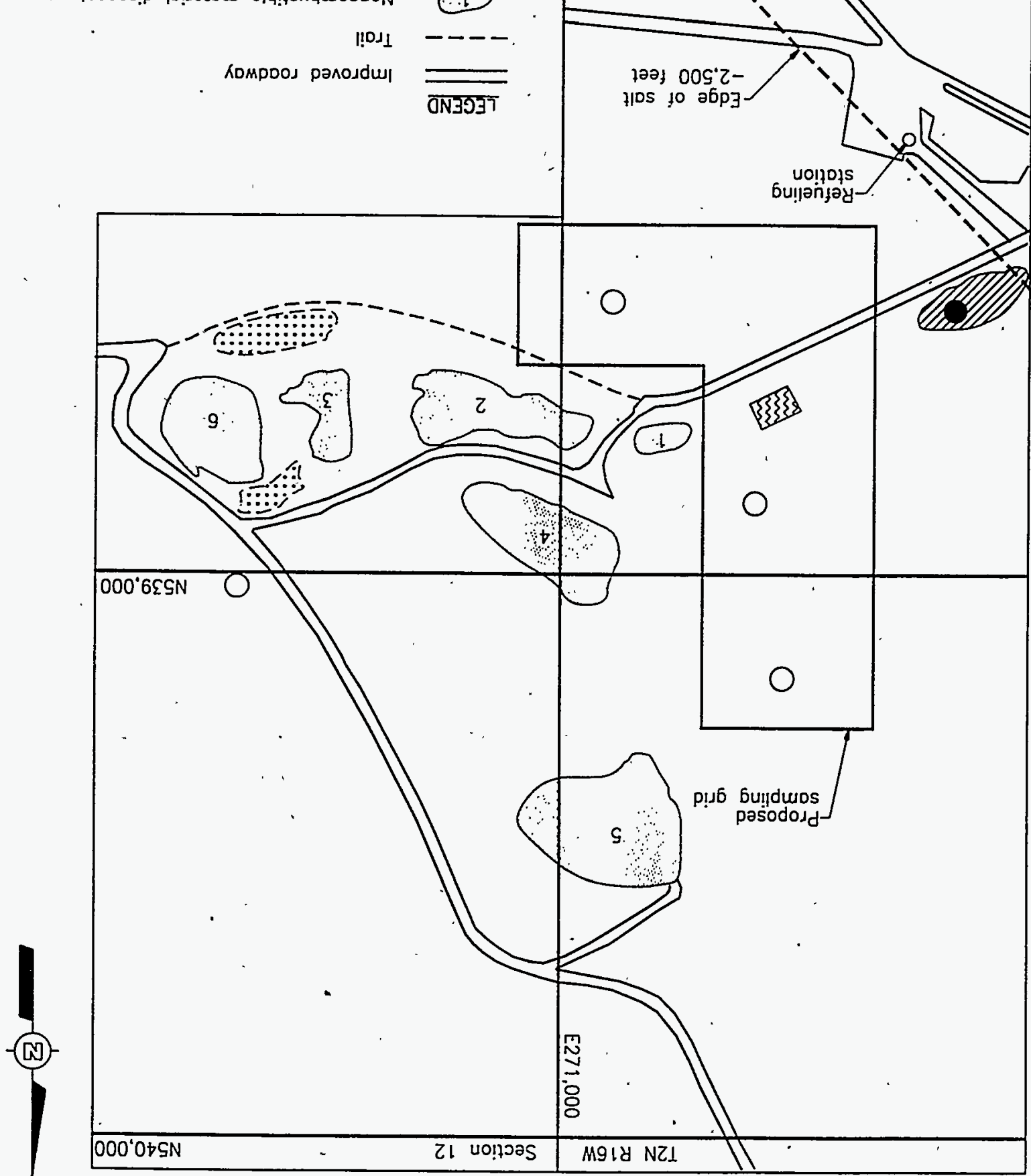

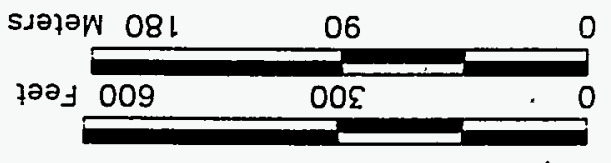

$\exists 7 \forall O S$

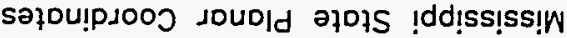




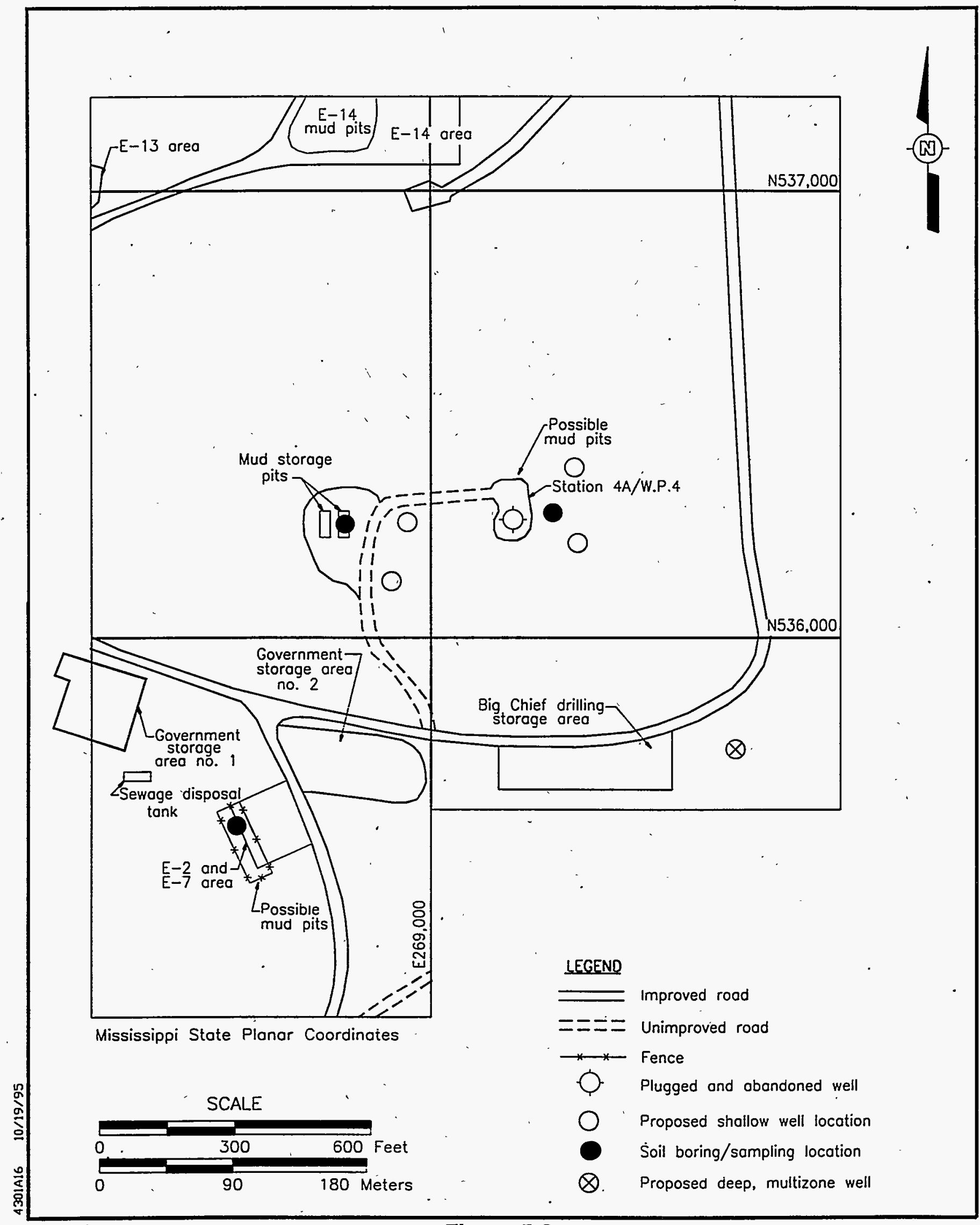

Figure 5-3

Planned Monitoring Well and Soil Boring Locations in Source Area 3 


\subsubsection{Source Area 3 - Mud Storage Area (Pits)}

Two shallow groundwater monitoring wells $(<21 \mathrm{~m}[<70 \mathrm{ft}])$ are planned for installation at this site. The purpose of these wells is to determine the nature and extent of possible contamination that may have resulted from the storage of drilling fluids. The placement of these wells was determined from the results the geophysical and CPT investigation.

Water and soil samples collected during the drilling and installation of these wells will be analyzed for those constituents listed in Table 4-2, tritium, and man-made radionuclides.

\subsubsection{Source Area 3 - Station 4 and W.P. 4 Drilling Sites}

Two shallow groundwater monitoring wells $(<15 \mathrm{~m}[<50 \mathrm{ft}])$ are planned for installation at this site. The purpose of these wells is to determine the nature and extent of possible contamination that may have resulted from the storage of fluids during the drilling of the two wells. The locations of these wells are approximate and were determined from knowledge of operations at the location. The final placement of the wells will be governed by the location of wetlands.

Water and soil samples collected during the drilling and installation of these wells will be analyzed for those constituents listed in Table 4-2, tritium, and man-made radionuclides.

\subsubsection{Source Area 4}

Two shallow groundwater monitoring wells $(<15 \mathrm{~m}[<50 \mathrm{ft}])$ are planned for installation at this site. The purpose of these wells is to determine the nature and extent of possible contamination that may have resulted from the storage of fluids during the drilling of the two wells. The placement of these wells is approximate and were determined from knowledge of operations at the location. The final placement of the wells will be governed by the location of wetlands (Figure 5-4).

Water and soil samples collected during the drilling and installation of these wells will be analyzed for those constituents listed in Table 4-2, tritium, and man-made radionuclides.

\subsubsection{Source Area 5}

Three wells are planned for installation into the Citronelle Aquifer to evaluate potential contamination of the aquifer by surface operations related to the drilling of the HT-2 well and injection operations. Two wells are planned in down gradient locations and one up gradient (Figure 5-5). 


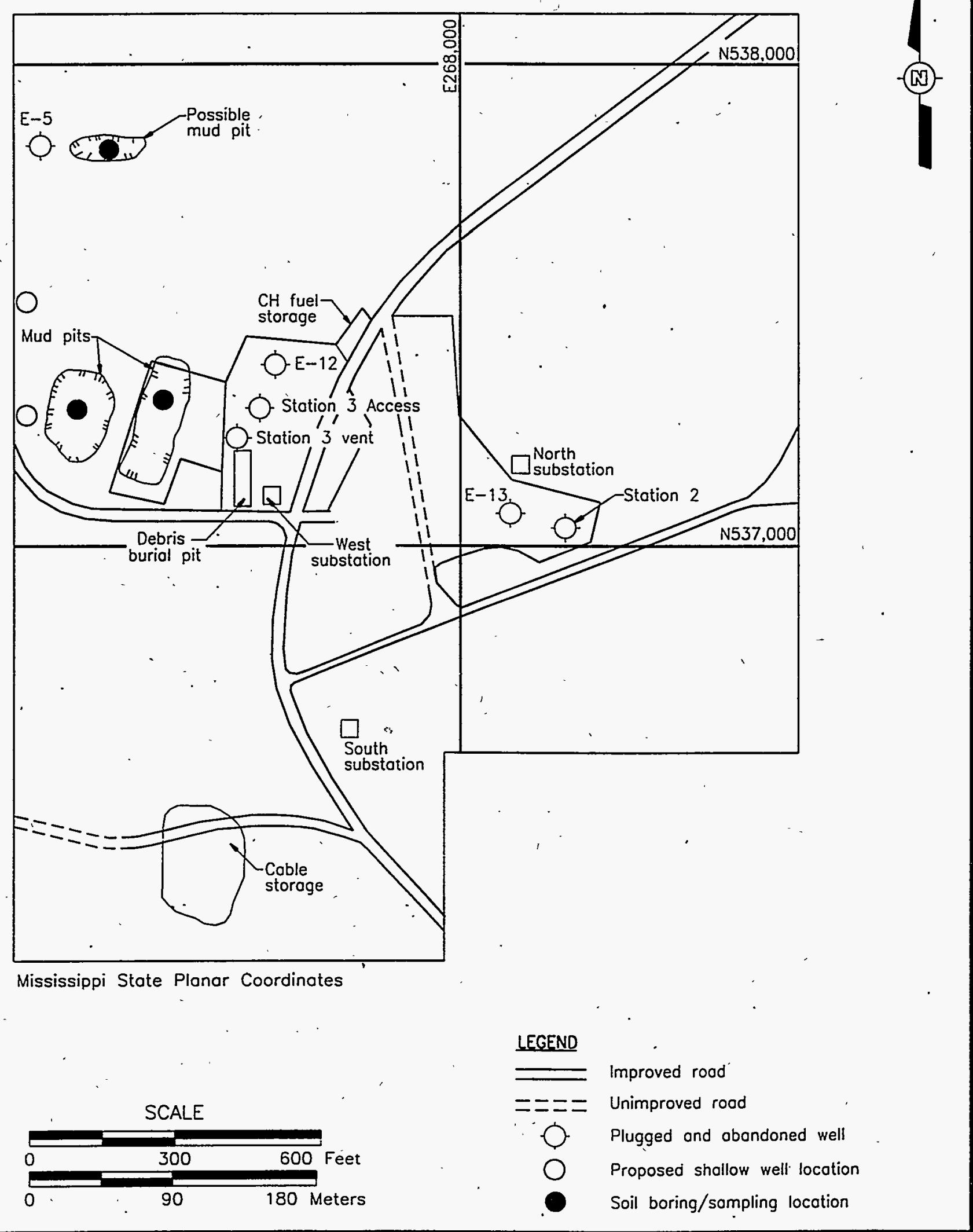

Figure 5-4

Planned Monitoring Well and Soil Boring Locations in Source Area 4 


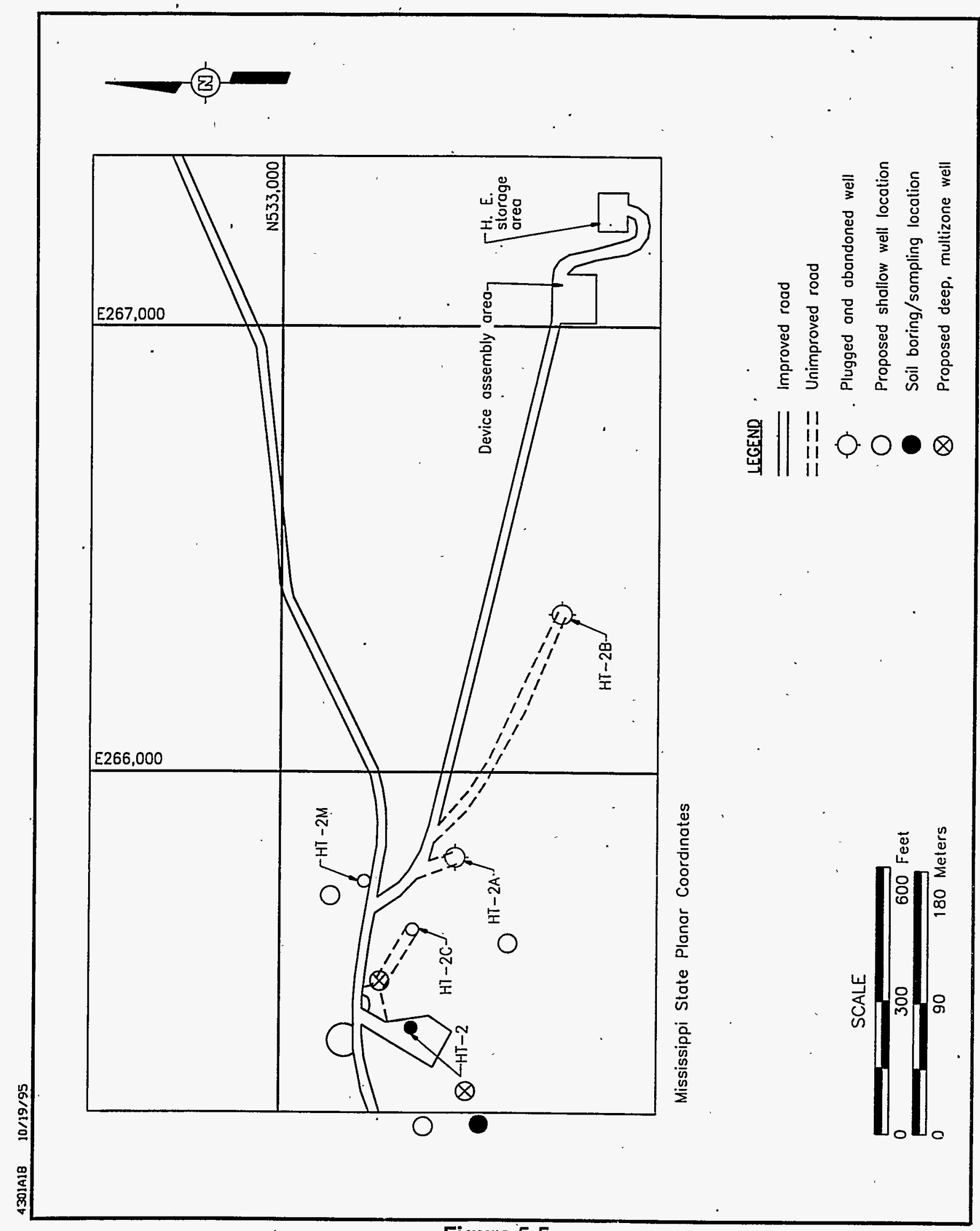

Figure 5-5

Planned Monitoring Well and Soil Boring Locations in Source Area 5 
Water and soil samples collected during the drilling and installation of these wells will be analyzed for those constituents listed in Táble 4-2, tritium, and man-made radionuclides.

Two wells are planned for installation into Aquifer 4. These wells will evaluate possible contamination of Aquifer 4 by migration from Aquifer 5. One well will be drilled up gradient and one well down gradient from well HT-2. If contamination is detected in Aquifer 4, then an additional well may be planned:

\subsubsection{Groundwater Sampling}

The objective of this subtask is to delineate any contaminant plumes in the groundwater. During this phase of groundwater sampling, existing wells and the new wells, installed during the Detailed Site Characterization, will be sampled.

Specifics concerning the location of the wells to be sampled, the number of samples and analytes, and sampling and testing protocols for each site are presented in Attachment 1, SAP for the SS RI/FS. Each well will be sampled and analyzed for tritium and for any chemical constituents detected during the groundwater collected during the preliminary characterization. Based upon the results of the analyses, and in consultation with the MS-DEQ, some or all of the wells will be incorporated into the long term monitoring program. The groundwater data collected during the preliminary phase and this subtask will be evaluated to establish sampling parameters (action compounds) which will be tested for in subsequent groundwater sampling events.

\subsubsection{Aquifer Testing}

After installation of the wells, aquifer tests will be conducted if additional data are required for any of the aquifers. Either step draw down or continuous discharge pump tests will be conducted. Slug tests maybe conducted in the shallow wells.

Work products to be generated during these subtasks will include as-builts for each well that is installed, updated water level and water chemistry maps and plots, and the results of any aquifer testing conducted. Also, a brief summary report presenting all data and analyses will be prepared. This report will identify any revisions that may be needed in the conceptual site model, detail the groundwater conditions at each source area and environmental medium, and provide recommendations for any additional groundwater characterization activities needed: 


\subsubsection{Geophysical Investigation}

Geophysical surveys will be used to delineate the buried waste pits and mud pits and to detect buried ferrous metal objects, such as drums or scrap metal. The methods that are proposed include Ground Penetrating Radar Electromagnetic Induction, and Electroconductivity.

\subsubsection{Soil Sampling}

This subtask will focus on screening the subsurface soils present at the SS. The purpose of this subtask will be to provide additional information about the nature and extent of contamination identified during the CPT investigation. In addition, newly identified sites (mud pits and a possible sewage disposal tank) will also be investigated during this phase. The information gathered will be used in both the Human Health Risk Assessment (HHRA) and Environmental Evaluation (EE), and will serve as baseline soil data to be evaluated in the RI process for the refinement of future task activities. Table 5-2 lists the planned soil boring locations, the approximate depths of each boring, and the purpose for each boring.

Table 5-2

Planned Soil Borings Listed by Site

\begin{tabular}{|c|c|c|c|c|}
\hline $\begin{array}{c}\text { Source } \\
\text { Area }\end{array}$ & Site & $\begin{array}{l}\text { Number of } \\
\text { Borings }\end{array}$ & $\begin{array}{c}\text { Depth } \\
\text { meters (feet) }\end{array}$ & Purpose \\
\hline 1 & E-14 Mud Pits & 1 & $9(30)$ & $\begin{array}{l}\text { Investigate possible contamination } \\
\text { associated with the E-14 drilling mud pits }\end{array}$ \\
\hline 2 & REECo pits & 2 & $9(30)$ & $\begin{array}{l}\text { Evaluate potential contamination in } \\
\text { drainage of the REECo Pits }\end{array}$ \\
\hline \multirow{4}{*}{3} & $\begin{array}{l}\text { Mud Storage } \\
\text { Area }\end{array}$ & 1 & $9(30)$ & Potential contamination from drilling fluids \\
\hline & $\begin{array}{l}\text { Station } 4 \text { and } \\
\text { W.P. } 4\end{array}$ & 1 & $9(30)$ & $\begin{array}{l}\text { Potential contamination from residual } \\
\text { drilling fluids }\end{array}$ \\
\hline & $\begin{array}{l}\text { Sewage } \\
\text { Disposal Tank }\end{array}$ & 1 & $9(30)$ & Possible unknown contaminants \\
\hline & E-2/E-7 Site & 1 & $9(30)$ & $\begin{array}{l}\text { Potential contamination from drilling fluids } \\
\text { used in the drilling of the wells }\end{array}$ \\
\hline \multirow{2}{*}{4} & $\begin{array}{l}\text { Reserve Mud } \\
\text { Pits }\end{array}$ & 2 & $9(30)$ & $\begin{array}{l}\text { Potential contamination from drilling fluids } \\
\text { used in the drilling of the wells }\end{array}$ \\
\hline & E-5 & 1 & $9(30)$ & $\begin{array}{l}\text { Potential contamination from drilling fluids } \\
\text { used in the drilling of the wells }\end{array}$ \\
\hline \multirow[t]{2}{*}{5} & HT-2 & 1 & $9(30)$ & $\begin{array}{l}\text { Possible contamination in drainage from } \\
\text { HT-2 drilling pad }\end{array}$ \\
\hline & E-3/E-9 Site & 2 & $9(30)$ & $\begin{array}{l}\text { Potential contamination from drilling fluids } \\
\text { used in the drilling of the wells }\end{array}$ \\
\hline
\end{tabular}


Shallow soil samples will be collected using either hand auger or power auger techniques employing a 5- or 10-cm (2- or 4-in.) diameter auger, a ring sampler, a split spoon, or a thin wall sampler. All samples 'will be analyzed for tritium and the constituents listed in Tables 4-2 and 4-3. All samples will be screened in the field for volatile organic compounds utilizing a photo ionization detector.

\subsubsection{Test Pit Excavation and Drum Sampling}

If necessary, additional trenches will be excavated into specific disposal cells to expose the buried wastes and collect samples of the wastes. If drums are exposed, they will be sampled either indirectly (using real time radiography) or directly. The samples will be tested to determine if they meet the RCRA criteria for hazardous wastes. If the results of these analyses indicate that the wastes are hazardous, then full chemical analyses will be done to identify the nature of the hazardous constituents present.

The objectives of this subtask are to define the volume of wastes that might require excavation and disposition, to characterize the nature and classification of the wastes present, to provide specific data for treatability studies, samples for bench scale and compatibility studies, and to provide required information for the RI Report. Because of the risk associated with this subtask, special provisions for trenching, drum sampling, and other field activities are included in the SAP (Attachment 1) and the HASP (Attachment 2).

Specific work products that will be prepared during this subtask include trench profiles, photodocumentation of exposed wastes, tables of analytical results, and maps showing the location, nature, and disposition of the wastes. A brief summary report detailing all procedures used and the results will also be prepared.

\subsection{Sample Analysis and Validation}

The soil and water samples that will be collected will be analyzed and a verification of these analyses and historic analyses will be performed. The objective of this task is to ensure that all data collected during the RI meet the specific quality assurance and quality control (QA/QC) requirements detailed in Attachment 1, Part 3, QAPP.

All laboratories used in the analyses of waste or environmental samples (soil, water, sediment, air, biota) will be CLP laboratories, or will use CLP-like or SDWA protocols. 
Data verification will consist of the review of all analyses and laboratory QA/QC programs and methodologies. The objectives of the data verification are to confirm that the data are representative of the media sampled, that all $\mathrm{QA} / \mathrm{QC}$ requirements have been met, and that data are compiled and transmitted in the form most applicable to the end uses of the data.

All data compilation, reduction, analysis, and synthesis will be verified to confirm that data used in the RI and the FS are accurate and that any uncertainties or limitations associated with the data are identified.

\subsubsection{Nature and Extent of Contamination}

During the detailed characterization of the SS, data will also be evaluated to provide a 3-dimensional characterization of the type, concentration, and volume of contaminated soils, groundwater, surface water, and sediments at the SS. Samples from the environmental media will be evaluated for hazardous, and radioactive constituents based on the DQOs. Spatial and temporal trends in contaminant extent and concentration will also be evaluated and the need for additional evaluations, such as contaminant transport modeling, discussed with the MS-DEQ.

This subtask will also compile the laboratory analyses and reduce the analyses to the appropriate form for evaluation and presentation. The data will generally be presented in the form of maps and tables. Trends will be presented in graphical form. The concentration of contaminants found at the site will be used in a baseline risk assessment to determine which are contaminants of concern.

Work products to be generated during this activity include text. for the RI Report and support figures, tables, and appendiceś.

\subsubsection{Contaminant Fate and Transport}

Data collected during the detailed site characterization phase of the SS RI/FS, with the information collected during the preliminary phases, will be evaluated during this subtask to . assess the fate of contaminants in the environmental media at the SS. This assessment will include the identification of pathways for exposure and the level of exposure. In performing this assessment. releases from the source will be considered along with the site conditions and natural processes that may affect the transport of contamination away from the site.

If the data collected during this phase is insufficient. then modeling of the groundwater system will be used to test conceptual models of the groundwater flow system, evaluate the potential for 
movement of radionuclides and other contaminants to receptor populations, and evaluate various remedial alternatives. To best simulate the geohydrologic setting, a three-dimensional model evaluating both flow and transport processes is ultimately envisioned, although cross-sectional modeling will be done first to evaluate different conceptual models and modeling approaches.

The model may need to be able to evaluate density-affected flow caused by brines. It may also need to evaluate radioactive-decay chains, depending on the nuclides detected during field investigations. Although it is premature to select a code for use in the modeling, SWIFT II or SWIFT III may be appropriate codes. These codes have been previously used in regulatory matters, and have been thoroughly verified against other codes. Code selection will not occur until early conceptual models have been developed.

Early and frequent discussions with regulatory personnel are anticipated in the modeling effort. Issues such as code selection, boundary conditions. material properties, and discretion need to be discussed with those who will evaluate results and depend on them in decision making, in order to develop confidence in the model as well cognizance in the shortcomings of the model. In addition to the formal process of work plan development and documentation of modeling results, fairly frequent informal working sessions will occur.

Development of a computer model of a flow system generally involves the following steps:

- Development of a database containing pertinent information such as:

- Lithology

- Hydraulic head

- Hydraulic conductivity and effective porosity

- Locations and rates of groundwater discharge

- Locations and rates of recharge

- Contaminant concentrations?

- Attenuation and retardation factors

- Development of a conceptual flow model

- Development and calibration of a numerical flow model

- Development and calibration of a numerical transport model

- Iterative recalibration of the previous steps

- Prediction of changes to the groundwater system or of contaminant transport

- Evaluation of the effects of data and model uncertainty on predictions

- Documentation of results and review.

A detailed work plan describing this general process and the interactions with regulatory personnel will be prepared. It is anticipated that as investigations proceed, problems and issues 
will develop; these will be resolved primarily through informal discussions among the parties, if possible. The goal of this process is to obtain the input from the regulatory community so that concerns are addressed early, rather than after considerable effort has been expended in developing the numerical models. Thus, flexibility through informal discussions is desirable. The formal process of review of the overall work plan and modeling results will occur as usual.

\subsubsection{Human Health and Environmental Risk Assessment}

As part of the RI, a baseline risk assessment will be completed. This assessment will provide an evaluation of the potential threat to human health and the environment in the absence of any remedial action. It will also provide the basis for determining whether remedial action is necessary and the justification for performing the required action.

This work will be completed in two parts: the HHRA and the EE. The HHRA will require the completion of subtasks for Data Collection/Evaluation, Exposure Assessment, Toxicity Assessment. and Risk Characterization. The EE will require completion of subtasks for Environmental Data Collection/Evaluation, Environmental Analyses, Toxicity Assessment, and Environmental Risk/Impact Characterization.

Objectives. purposes, and methodologies for these assessments are given in the SAP (Attachment 1) and presented in the'EEW (Attachment 1, Part 2). Other specific information. required to complete these assessments include DQOs (Section 4.1.1), ARARs (Section 3.2), and media-specific analyses (Section 4.2). 


\subsection{Project Schedule}

Major milestones for the SS RI/FS are listed in Table 6-1. The anticipated schedule for completing the remainder of the SS RI/FS project is illustrated in Figure 6-1. The original overall schedule encompassed a total of thirty-eight months for the completion of the RI/FS process; however, site access problems have delayed the completion of this process. As agreed upon by the DOE and MS-DEQ, the schedule has incorporated thirty-day MS-DEQ review periods for all.project deliverables. The DOE/NV believes that this schedule is both reasonable and achievable.

Many variables exist that could affect the final schedule, including resource commitments; funding by U.S. Department of Energy Headquarters (DOE/HQ) of the initial RI data gathering efforts; availability of suitable treatability processes and data; and federal, state, and public dispute resolutions, should they occur. The DOE/NV is committed to working with the MS-DEQ to maintain the RI/FS schedule, and should any delays be anticipated, DOE/NV will provide prompt notification.

Table 6-1

Major Milestones for the Salmon Site RI/FS Project

\begin{tabular}{|l|c|}
\hline \multicolumn{1}{|c|}{ Milestone } & Anticipated Complete Date \\
\hline \hline Complete Installation of Auger Wells & $11 / 13 / 95$ \\
\hline Completion of Soil Borings and Analysis & $01 / 12 / 96$ \\
\hline
\end{tabular}

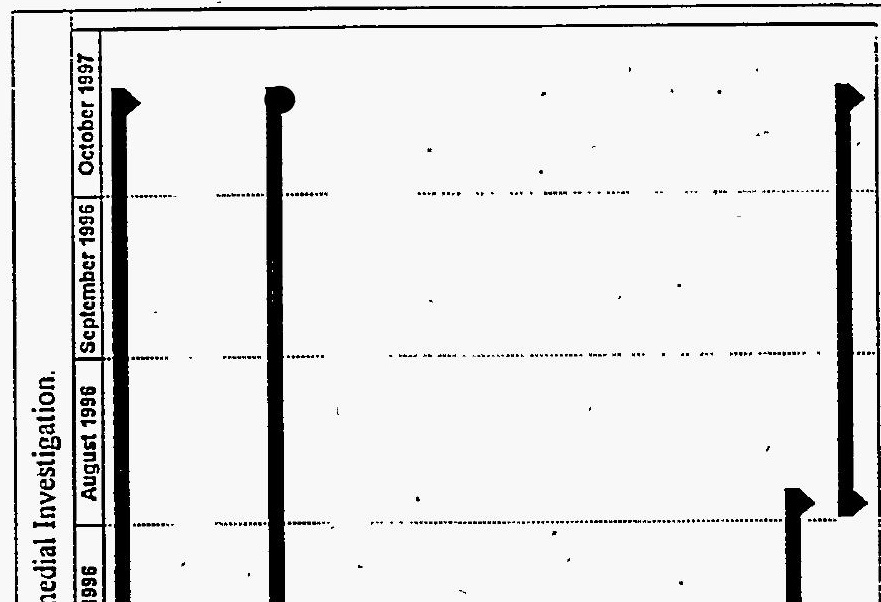




\subsection{Project Management}

This chapter describes the management of the SS RI/FS subproject within the context of the Nevada Environmental Restoration Project (NV ERP). This chapter is considered to be a subtiered document of the NV ERP PMP. Consequently, some elements of the PMP apply to all NV ERP activities and, therefore, are not repeated'here.

The principal SS participants include DOE/HQ, DOE/NV Environmental Restoration Division, and IT Corporation (IT).

In addition to the PMP and this chapter, there are many technical and administrative documents necessary to execute the SS subproject in accordance with all DOE and regulatory requirements. These documents, and their current status (i.e., draft or final editions), include the following:

- Nevada Environmental Restoration Project Management Plan (Final)

- Nevada Environmental Restoration Project Strategic Plan (Final)

- Nevada Environmental Restoration Project Technical Strategy Plan (Draft)

- Nevada Environmental Restoration Project Baseline (Final)

- Nevada Environmental Restoration Project Health and Safety Project Plan (Final)

- Nevada Environmental Restoration Project Data Management Plan (Final)

- Salmon Site Community Relations Plan (Final).

An extensive list of management guidance documents has been compiled and discussed in Section 1.4 of the NV ERP PMP. Nevada Environmental Restoration Project management documents apply to SS subproject activities.

\subsection{Management Organization and Responsibilities}

\subsubsection{DOE Headquarters}

The DOE/HQ Office of Environmental Restoration (EM-40) is responsible for establishing DOE environmental policy and approving budget submittals and changes to scope, budget, and schedule, above thresholds designated by EM-40. Responsibility for the SS falls within the EM-40 Office of Southwestern Area Programs (EM-45).

\subsubsection{Office of the Manager, DOE/NV}

The Office of the Manager oversees management and operations of the NTS and other off-site test locations. The Office of the Manager is responsible for safeguarding the environment and 
ensuring the safety and health of all participants in DOE/NV programs. The Manager has overall authority and responsibility to ensure that an effective NV ERP is maintained consistent with EM-40 guidance, including responsibility for approving both budget and schedule objectives.

\subsubsection{Assistant Manager for Environmental Restoration and Waste Management}

The Assistant Manager for Environmental Restoration and Waste Management (AMEM) organization consists of three divisions: the Environmental Restoration Division, the Waste Management Division (WMD); and the Project Control and Technology Development Division (PCTDD). Among the responsibilities of the WMD that could affect the SS are management of low-level radioactive, mixed, and hazardous waste operations at the NTS; performance of audits of on-site waste generators to ensure compliance with DOE/NV waste-disposal requirements; oversight of the development of the data, information, and documentation necessary to obtain state and federal permits to operate WMD waste management facilities; oversight of the NTS shipping and receiving programs for radiological and nonradiological hazardous materials; and management of the radiological and hazardous waste minimization program.

The PCTDD is responsible for program support integration across the three AMEM divisions and for the management and development of environmental measurement and protection technology. In addition, the PCTDD provides technical guidance for the DOE/NV applied research and technology development program to improve the techniques for environmental remediation and characterization. This responsibility includes work to resolve technical issues related to minimizing the volume of radioactive and hazardous waste handled and generated.

\subsubsection{Environmental Restoration Division}

The AMEM has delegated responsibility for day-to-day management of the NV ERP to the Director of the Environmental Restoration Division. The Director of the Environmental Restoration Division is the Contracting Officers Representative for the IT Contract. A detailed list of responsibilities for the Environmental Restoration Division is given in DOE Order NV 11XA.1, Organization and Functions. The following provides a summary of Environmental Restoration Division functions:

- Preparation and monitoring of performance against the ERP management plans and programmatic control documents, including the baseline and Activity Data Sheets (ADS)

- Tracking of cost and schedule status associated with the ERP 
- Management of the Environmental Support Services Contractor (IT Corporation)

- Integration of ERP activities into the Five-Year Plan. Site-Specific Plan, Road Map, and similar DOE/HQ and DOE/NV planning documents

- Determination of the need for and development of proper NEPA documentation for Environmental Restoration activities

- Management of the SS as a subproject within the overall scope of the NV ERP.

The Director of the Environmental Restoration Division delegates responsibility and authority for the day-to-day management of individual subprojects within the NV ERP to Environmental Restoration Division Subproject Managers. The Director of the Environmental Restoration Division maintains communication with the AMEM and other division directors through biweekly staff meetings, informal meetings, memoranda, and telecommunications. The Director of the Environmental Restoration Division also maintains communication with the Environmental Restoration Division Subproject Managers through staff meetings, informal meetings, memoranda, and telecommunications.

\subsubsection{Salmon Site Manager}

The Manager for the SS reports directly to the Director of the Environmental Restoration Division and is responsible for maintaining accountability, subproject planning, and execution within approved cost and schedule objectives. The Manager is responsible for the following activities for the SS:

- Direction, development. implementation and management of SȘ RI/FS

- Coordination of scientific and engineering experts responsible for the management of scientific and technical design

- Development, review, and consolidation of budget and financial plans, including monitoring compliance with budget and financial constraints and allocation of contingency funds

- Implementation of a management control system and applicable reports for control and evaluation of technical, schedule, and cost performance of contractors pursuant to DOE Orders 4700.1 (Change 1), 4700.5; Project Control System Guidelines; and 1332.1A, Uniform Reporting System

- Development of technical. cost, and schedule objectives and the baseline

- Consolidation and submission of periodic subproject assessment reports to the AMEM and EM-40 through the Director, Environmental Restoration Division 
- Development of QAPPs and HASPs in accordance with DOE and other regulatory program requirements

- Development of designs that are consistent with acceptable construction practices, thereby minimizing the risks to construction personnel's health and safety during well construction, testing, and completion

- Coordination of community relations activities as outlined in the SS Community Relations Plan

- Approval of changes to scope, schedules, and budgets within the limits established by EM-40 and the AMEM, and coordination of the required approvals for changes to scope, schedules, and budgets that will impact the subproject technical objectives, total estimated costs, or schedules

- Day-to-day coordination with the MS-DEQ and MS-DOH to ensure appropriate regulatory input and approval.

\subsubsection{IT Corporation}

As the Environmental Services Support Contractor, IT's responsibilities include:

- Subproject management support, including the preparation of the ADS, baseline scope, schedules, and budget for the SS, as deemed appropriate by DOE/NV

- Programmatic plannıng and management support services deemed appropriate by DOE/NV

- Development and implementation of the subproject-specific QAPP and site-specific HASPS

- Development of environmental and decision-basis documentation in support of the SS

- Development and maintenance of procedures for SS activities in accordance with DOE and all pertinent regulatory guidelines and requirements, and assurance that all work performed for the SS meets the requirements defined in the procedures

- Acquisition, integration. management. and analysis of radiological. chemical geologic, hydrologic, geophysical, meteorological, and other technical and nontechnical data to support the SS, as deemed appropriate by DOE/NV

- Preparation of technical contributions to community 'relations programs and interaction with regulatory agencies in support of DOE/NV

- Procurement and oversight of subcontractors to perform various studies, as deemed appropriate by DOE/NV 
- Performance of a baseline risk assessment and other risk evaluations associated with the SS

- Implementation of this addendum and all supporting activities.

\subsubsection{U.S. Environmental Protection Agency}

Responsible for continuing the Long-Term Hydrologic Monitoring Program for SS. 


\subsection{References}

AEC, see U.S. Atomic Energy Commission.

Baldwin, D.A., U.S. Department of the Interior Geological Survey, 1968, Aquifer-Response Measurements for the Sterling Event, Tatum Dome, Lamar County, Mississippi, Technical Letter Dribble-54.

Borg, I.Y., R. Stone, H.B. Levy, and L.D. Ramspott, Lawrence Livermore National Laboratory, 1976, Information Pertinent to the Migration of Radionuclides in Ground Water at the Nevada Test Site, Part I: Review and Analysis of Existing Information, UCRL-52078.

Brady, D.N. and E.L. Milton, Reynolds Electrical \& Engineering Co.. Inc., 1972, Tatum Dome Test Site Final Cleanup Report, Environmental Sciences Department.

Chapman, J.B. and S.L. Hokett, May 1990, Evaluation of Groundwater Monitoring at Offsite Nuclear Test Areas.

Church, B.W., Nevada Opérations Office, U.S. Atomic Energy Commission, date, What Can be Learned from the Cleanup of the Tatum Dome Test Site. Hattiesburg, Mississippi.

Cushing, E.M., E.H. Boswell; P.R. Speer, R.L. Hosman. and others, 1970, Availability of Water in the Mississippi Embayment. Geological Survey Professional Paper 448-A.

DOE. see U.S. Department of Energy:

Eargle, D.H.: 1968, Stratigraphy and Structure of the Tatum Salt Dome Area, Southeastern Mississippi and Northeastern Washington Parish, Louisiana, Geological Society of America Special Paper 88, International Conference on Saline Deposits. p. 381-405.

Eargle, D.H., J.W. Lang, and J. Schlocker, 1965, "Tatum Dome, Mississippi, Site of Atomic Explosion, Project Dribble", Bulletin of the American Association of Petroleum Geologists, Volume 49, Number 3.

EG\&G, 1979, Aerial Photograph, Photo No. 2880, May 27; 1979.

EPA, see U.S. Environmental Protection Agency.

Fenix \& Scisson, Inc., U.S. Energy Research and Development Administration, 1975, Remedial Work on HT-2M, HT-1, Ascot No. 2, Tatum Dome, Hattiesburg, Mississippi.

Fenske, P.R. and T.M. Humphrey Jr., U.S. Department of Energy, Nevada Operations Office, 1980, The Tatum Dome Project Lamar County, Mississippi, NV-225. 
Heath, R.C., 1984, Ground-Water Regions of the United States, U.S. Geological Survey WaterSupply Paper 2242, pages i, 17, 52-55.

Holmes \& Narver, Inc., UNDATED, Composite Site Map - Project Dribble, Unknown I.D. No., Unknown Drawing No.

Holmes and Narver, Inc., 1969, Tatum Dome, Lamar County, Miss. Dribble Program, Seismic Profiling Experiment, Project 7.29 Location Plan; Drawing Number: JS-E-002-C14.

Holmes \& Narver, Inc., 1972, Composite Site Map, Tatum Dome Test Site, Lamar County, Mississippi, Status of Decommisssioning - 1972, I.D. No. 4602, Drawing No. E-002-C19.

Holmes \& Narver, Inc., U.S. Atomic Energy Commission, Nevada Operations Office, 1972, Final A-E Report of Site Disposal Tatum Dome Test Site Lamar County, Mississippi.

IT Corporation, 1992, Results of a Preliminary Survey for Threatened and Endangered Species and Floodplains/Wetlands at the Tatum:Dome Test Site, Lamar County, Mississippi, . Las Vegas, NV, October 1992.

Medely, A.H., Fenix and Scission, Inc., 1972, Status of Government Drilled Holes, Tatum Domé Test Site, Hattiesburg, MS.

MS-DEQ, see Mississippi Department of Environmental Quality.

MS-DOH, see Mississippi Department of Health.

Mississippi Department of Environmentai Quality, 1991, Letter from the Mississippi Department of Environmental Quality, Hazardous Waste Unit, to the U.S. Department of Energy, Las Vegas Office. Environmental Restoration Division. including comments regarding the Draft Final RI/FS Work Plan for Tatum Dome Test Site. Lamar County, March 14, 1991.

Mississippi Department of Health, Division of Radiological Health, 1990, Tatum Salt Dome Radiological Monitoring, Annual Report. Jackson, MS.

Mississippi Department of Health, Division of Radiological Health, 1991, Tatum Salt Dome Radiological Monitoring, Annual Report, Jackson, MS.

Mississippi Department of Health, Division of Radiological Health, 1992, Tatum Salt Dome Radiological Monitoring, Annual Reporn, Jackson, MS.

Mississippi Department of Health, Division of Radiological Health, 1993, Salmon Test Site Radiological Monitoring, Annual Report, Jackson, MS.

Nevada Operations Office, 1978, Special Study, Tatum Dome Test Site, Mississippi, NVO-143. 
Nevada Operations Office. 19.72, Cleanup Summary Report, Tatum Dome Test Site, Mississippi, NVO-129.

Newcome, R.. U.S. Geological Survey,.1976, The Miocene Aquifer System in Mississippi, Jackson, MS.

NVO, see Nevada Operations Office.

Payne, J.N., 1968, Hydrological Significance of the Lithofacies of the Sparta Sand in Arkansas, Louisiana, Mississippi, and Texas, U.S. Geological Survey Professional Paper 569-A.

Physical Sciences Division, March 1975, Long-Term Radiological Surveillance Program. Tatum Dome Test Site, Hattiesburg; Lamar County, Mississippi, NVO-143.

Pinson, J.W., Ph.D., U.S. Department of Energy and U.S. Environmental, 1979, Tritium Analysis of the Tatum Salt Dome Area. Report No. 1.

PSD, see Physical Sciences Division.

Spiers, C.A. and L.A. Gandl, 1980, A Preliminary Report of the Geohydrology of the Mississippi Salt Dome Basin, U.S. Geological Survey, Water Resources Investigations Open-File Report 80-595.

The Earth Technology Corporation, 1982, Status Report on Modeling Regional Ground-Water Flow Near Richton Dome, Mississippi, Office of Nuclear Waste Isolation.

TETC, see The Earth Technology Corporation.

U.S. Atomic Energy Commission. 1965, Tatum Dome, Mississippi, Project Dribble Disposal Pits Location Plan. I.D. No. 34124, Drawing No. JS-E-094-C18.

U.S. Atomic Energy Commission, 1972, Cleanup Summary Report - Tatum Dome Test Site Mississippi, NVO-129.

U.S. Atomic Energy Commission, 1970, Letter from B.W, Monke, Assistant Manager for Administration to F.I. Scrable, Executive Vice President, Reynolds Electrical and Engineering Company, regarding the Tatum Salt Dome Site disposal (October 30, 1970).

U.S. Department of Energy, 1979, Tatum Dome Drilling and Radiological Monitoring Plan, Nevada Operations Office, NVO-205.

U.S. Department of Energy, 1993, Remedial Investigation/Feasibility Study of the Tatum Dome Test Site, Lamar County, Mississippi.

U.S. Department of Energy, 1994a, Preliminary Data-Report of Investigation Conducted at the Salmon Site. Lamar County, Mississippi, DOE/NV-369-UC70. 
U.S. Department of Energy, 1994b, Trench Sampling Report, Salmon Site, Lamar County, Mississippi, DOE/NV-373-UCC700.

U.S. Department of Energy, 1994c. Task Summary for Cone Penetrometer Testing, Soil and Groundwater Sampling Site, Lamar County, Mississippi, DOE/NV-381-UC70.

U.S. Department of Energy, 1994d, Geophysical Investigation, Salmon Site, Lamar County; Mississippi, DOE/NV-391.

U.S. Department of Energy, 1995, Baseline Ecological Assessment of the Salmon Site, Lamar County, Mississippi, DOE/NV-394-UC-700.

U.S. Environmental Protection Agency, 1988, Guidance for Conducting Remedial Investigations and Feasibility Studies Under CERCLA, Office of Emergency and Remedial Response, Washington, DC, EPA/540/G-89/004. 



\section{Distribution List}

\section{$\underline{\text { Copies }}$}

Robert Bell

Mississippi Dejpartment of Health

Division of Radiological Health

P.O. Box 1700

Jackson, Mississippi 39215-1700

Bill Bishop

48 Pennington Loop

Purvis, Mississippi 39457

Roxanne Danz

1

DOE/Nevada Operations Office

P.O. Box 98518

Las Vegas, Nevada 89193-8518

Dr. Fred Howell

Department of Biological Sciences

University of Southern Mississippi

P.O. Box 5018

Hattiesburg, Mississıppi 39.406

IT Corporation

+330 S. Valley View. Suite 114

Las Vegas, Nevada 89023-0345

Ethan Merril

U.S. Department of Energy Headquarters

12800 Littlebrook Road

Germantown. Maryland 20874

Anita Mullen

U.S.'Environmental Protection Agency

Environmental Monitoring Systems Laboratory

P.O. Box 93478

Las Vegas. Nevada 89193-3478

Purvis Library

Purvis, Mississippi 39475

U.S. Department of Energy

Nevada Operations Office

Technical Information Resource Center

P.O. Box 98518

Las Vegas, Nevada 89193-8518 
Copies

U.S. Department of Energy

2

Office of Scientific and. Technical Information 175 Oak Ridge Turnpike

P.O. Box 62

Oak Ridge. Tennessee 37831

Phillip Weathersby

4

Mississippi Department of Environmental Quality

Office of Pollution Control

P.O. Box 10385

Jackson, Mississippi 39289-0385 